Historic, Archive Document

Do not assume content reflects current scientific knowledge, policies, or practices. 


\section{WALTER A.POTTER \&CO}

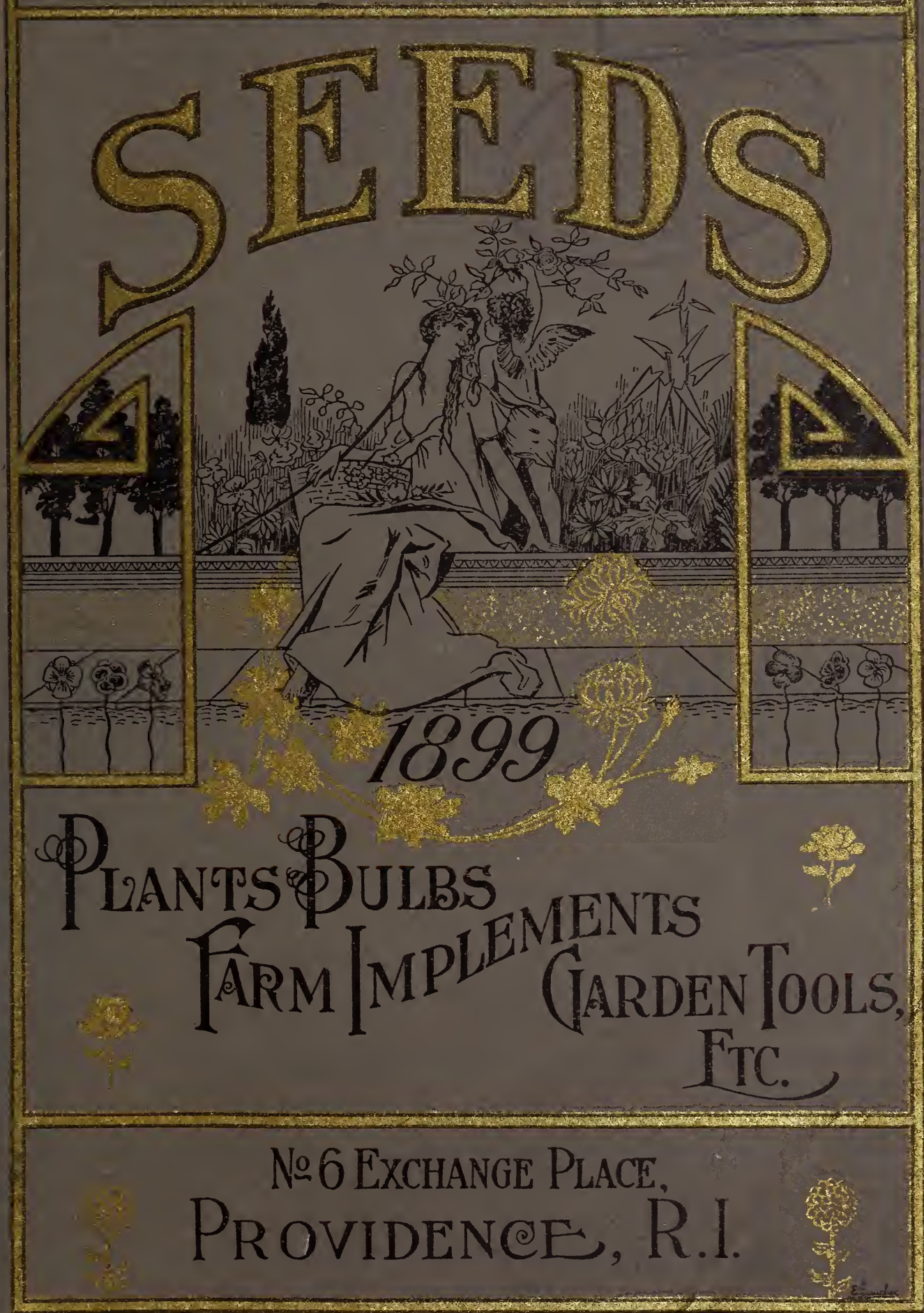




\section{Useful Tables.}

\section{QUANTITY OF SEED USUALLY SOWN PER ACRE.}

Barley, broadcast,

Beans, dwarf, in drills

Beans, pole, in hills,

Beets, in drills,

Buckwheat,

Cabbage, in beds to transplant.

Carrot, in drills,

Chinese Sugar Cane,

Clover, red, alone,

Clover, white, alone,

Clover, Alsike, alone,

Clover, Lucerne or Alfalfa,

Corn, in hills,

Corn for soiling,

Cucumber, in hills

Grass, Kentucky Blue,

Grass, Orchard, -

Grass, English Orchard,

Grass, Fowl Meadow

Grass, Red Top,

Grass, Timothy, -

Grass, Hungarian,

Grass, Mixed Lawn,

Mustard, broadcast,

Melon, Musk, in hills,
2 to 3 bushels

$11 / 2$ hushels

so to 12 quarts

-5 to 6 pounds

- I bushel

$1 / 2$ pound

2 to 3 pounds

12 quarts

15 to 20 pounds

12 to 15 pounds

8 to 10 pounds

20 pounds

7 to 10 quarts

3 bushels

- 2 pounds

3 bushels

- 3 bushels

2 bushels

- 2 bushels

3 bushels

- $1 / 2$ bushel I bushel

4 bushels

$1 / 2$ bushel

2 to 3 pounds
Melon, Water, in hills,

Millet, Common, broadcast,

Oats, broadcast,

Onion, in drills,

Onion for sets, in drills

Onion Sets, in drills,

Parsnips, in drills,

Peas, in drills,

Peas, broadcast,

Potato, (cut tubers)

Pumpkin, in drills, .

Radish, in drills, .

Rye, broadcast,

Sage, in drills,

Spinach, in drills,

Squash, bush varieties, -

Squash, running varieties,

Tomato, to transplant,

Turnip, in drills,

Turnip, broadcast,

Wheat, broadcast

Clover, together

Tinothy, $\left\{\begin{array}{l}\text { for } \\ \text { fin }\end{array}\right.$

Red Top, one acre, or -

Red Top, clear seed,
4 to 5 pounds

- I bushel

- 2 to 3 bushels

4 to 5 pounds

30 pounds

6 to 12 bushels

-4 to 6 pounds

I $1 / 2$ bushels

3 bushels

ro bishels

4 to 5 pounds

$S$ to 10 pounds

$11 / 2$ to 2 bushels

$S$ to ro pounds

10 to 12 pounds

4 to 6 pounds

- 3 to 4 pounds

$1 / 2$ pound

$11 / 4$ to 2 pounds

-2 to 3 pounds

$11 / 2$ to 2 bushels

- 8 pounds Clover

12 quarts Timothy

I bushel Red Top 4 pounds

\section{QUANTITY OF SEED REQUIRED FOR A GIVEN NUMBER OF HILLS OR LENGTH OF DRILLS.}

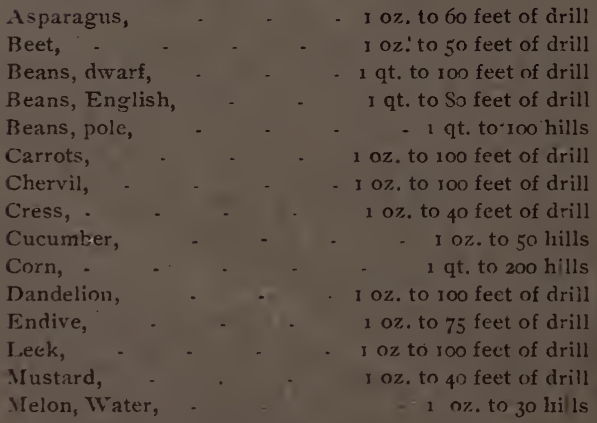

Melon, Musk, Okra,

Onion, .

Onion Sets, small

Parsley,

Parsnip,

Peas,

Pumpkins,

Radish,

Salsify,

Spinach.

Sorrel,

Squash, early,

Squash, running,

Turnip,
I $0 z$. to 60 hill! 1 oz. to 40 feet of dril $1 \mathrm{Oz}$. to 100 feet of dril I gt. to 40 feet of dril I $0 \%$. to 150 feet of drit I oz. to 200 feet of drill 1 qt. to soo feet of dril $1 \mathrm{oz}$, to 40 hills $1 \mathrm{oz}$. to 150 feet of dril

$1 \mathrm{oz}$, to 7 o feet of drill y oz. to 100 feet of drill $1 \mathrm{oz}$. to 100 feet of drill I oz. to 50 hills: I oz. to 6 hilils x 07. to 150 feet of dril

\section{NUMBER OF PLANTS RAISED FROM ONE OUNCE OF SEED.}

Tomato,

Pepper,

I.ettuce,
1,000 Plants

$1,0 \mathrm{cn}$ Plants

3,000 I'lants
Celerv,

Caulihower.

Cabisage. 2,5no Plats 1,500 Plants 2,000 Plant

Egg Plant,

1,000 Plants 


\section{* $1899 *$}

\section{..Annual Catalogue..}

Garden, Field and Flower

Bulbs, Plants, Fertilizers

and Implements for the Farm and Garden

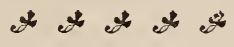

WALTER A. POTTER \& CO.

$$
\frac{6 \text { Exchange Place }}{\text { Providence, R. I. }}
$$




\section{9}

\section{TO OUR CUSTOMERS.}

$\mathrm{W}$

E again have the pleasure of presenting our Annual Catalogue of selected Seeds, Bulbs and Plants and of our extensive line of improved Horticultural and Agricultural requisites, and take this opportunity of thanking our friends for their liberal patronage of the past, and by fair dealing and the desire to offer only the best, hope to merit a continuance of your favors.

Seeds by Mail. All Seeds ordered at ounce, package and one-quarter pound rates are sent by mail prepaid. All seeds in bulk from four ounces and up, postage to the amount of eight cents per pound must be added to our catalogue prices. All heary Seeds such as Peas, Beans, Corn, Seed Grain, Roots, etc., we do not send free as such are quoted at net prices at our store.

Seeds in Packets. All Vegetable Seeds, except Peas, Beans and Corn, are supplied at 5 cents per packet unless otherwise noted.

Discounts. On all orders for Seeds in packets accompanied by the money, purchasers will be allowed to select 25 cents worth extra for each $\$ 1$.oo sent.

Seeds by Weight. We supply one-half pounds and over at pound rates; less than one-half pound lots are charged at one-quarter pound rates; less than one-quarter pound lots at ounce rates. The smallest quantity of flower seed we weigh is ten cents value.

Remittances may be made by Post Office Money Order, Express Money Order or in Registered Letter. Small amounts may be sent in Postage Stamps.

Bags Used in Packing are charged at the following rates: one-quarter bushel and halfbushel ten cents each. One bushel and two bushel at fifteen cents each. If returned within sixty days sound and in good condition, free of expense, the above prices will be refunded.

\section{Names, Addresses, Etc.}

In ordering please see that you sign your name, also that of your post office and county be plainly written, as we are in receipt each year of several orders sent in without name which cause a great deal of inconvenience and delay to the sender.

Other Copies of this Catalogue will be sent to any of your friends who use Seeds, Bulbs, etc., if you will send us a list of their names and post office addresses. Our annual Illustrated Catalogue of Bulbs for Fall Planting will be issued in September and mailed to our customers. We import these Bulbs from some of the oldest and most reliable growers in France and Holland, and parties entrusting us with their orders will find them equal to those sold by any reputable house.

While we exercise the greatest care to have all Seeds pure and reliable, we do not give any warranty, expressed or implied. If the purchaser does not accept the Seeds on these terms and conditions, they must be returned at once, and the money that has been paid for same will be refunded. 


\section{VEGETABLE SEEDS.}

\section{Asparagus.}

Sow in spring as early as the ground can be worked, in drills one foot apart, covering the seed one inch deep. Thin the plants to three inches in the rows. Cultivate during summer, and give the plants a light covering of stable-litter during winter. When two years old they may be transplanted into permanent beds, setting the plants four inches beneath the surface, in rows two feet apart, and the plants one foot apart in the rows. The soil should be well trenched and highly manured to insure a good crop.

Conover's Colossal.....................................10 20 . $\$ 50$

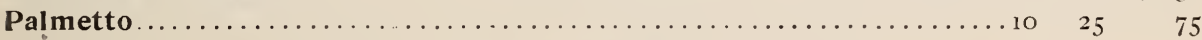

\section{Asparagus Roots.}

Conover's Colossal-Two years old .......................\$6 oo

Per 1000 Per 100

Palmetto-Strong, two years old......................... 7 o

\section{Beans-Dwarf or Bush.}

A succession of sowings can be made frcm the first week in May until September. Plant in rows eighteen inches apart and two inches deep, according to the richness of the soil. All the following varieties of beans are very sensitive to frost and cold. Hoe only when dry, as the scattering of earth on the foliage or pods when moist, will cause them to become damaged with rust.

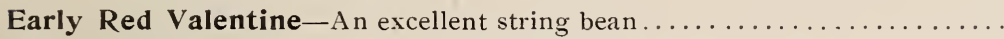

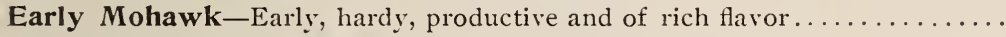

Early Yellow Six Weeks - Very early, popular string bean .............

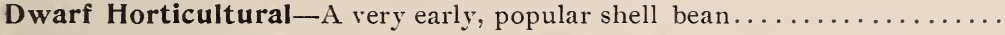

Low's Champion-Excellent string or shell bean; early................

Goddard, or Boston Favorite-An improved variety of the Dwarf Horti-

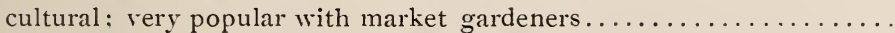

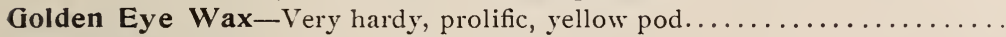

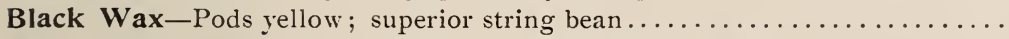

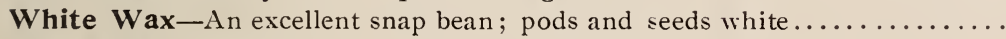

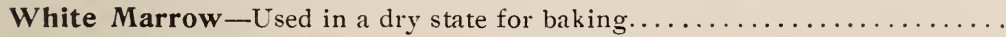

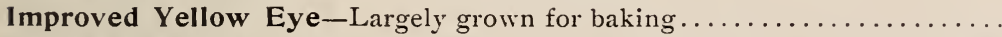

Henderson's Bush Lima-A dwarf variety of the Sieva, or small Lima:

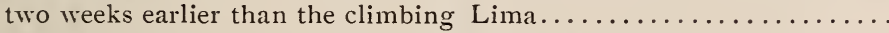

Burpee's Bush Lima-A true bush form of the large Lima.............

Rust=Proof Golden Wax-The standard variety for general use; pods long

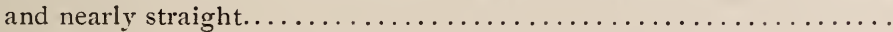

Valentine Wax-A perfect Valentine bean, with round, wax pods..........

Wardwell's Kidney Wax-Pods flat, very long and nearly straight; one of

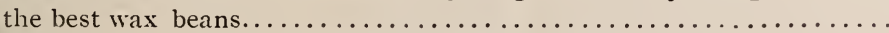




\section{Beans-Pole, or Running.}

These are more tender and require more care in culture than the Bush Beans, and should be sown two weeks later than those. Plant in hills about three feet apart, putting four or five beans in a hill, and leaving a space in the centre for the pole. They succeed best in sandy loam, which should be liberally enriched with short manure in the hills. Lima and Sieva Beans will not grow until the weather and ground are warm.

Pole Horticultural $-A$ popular variety for private garden use ............ Qt Peck

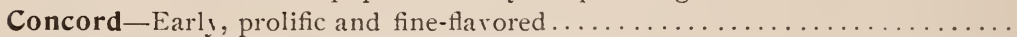

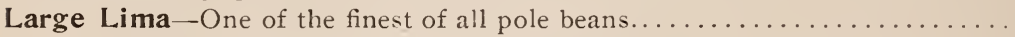

Dreer's Improved Lima-Superior quality; early ...................

Sieva, or Small Lima-Earlier and hardier than the large Lima

Scarlet Runner-Very ornamental climber with bright scarlet flowers........

White Runner-Similar to the preceding, except flowers are white.........

English Broad Winsor-Best for general use.

Hampden Pole_Pods large, bright carmine; very productive.............

\section{Beets.}

The soil which is best suited for the culture of the Beet is that which is rather light than otherwise, always provided it is thoroughly enriched with manure. For an early supply sow in spring, as soon as the ground becomes fit to work, in drills, about one foot apart and two inches deep. For main crop, sow early in $\mathrm{May}$ and for winter use, sow in June. Thin out to six inches apart and hoe frequently. In October the roots may be taken up and stored in cellar or in pits, outside like potatoes, care being taken that they are not bruised or injured in the process.

Early Eclipse-One of the best early varieties $O z+L b \quad I, b$

Edmand's Early Blood Turnip-One of the best; round, good size: dark

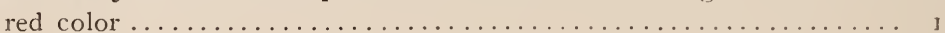

Detroit Dark Red-Very crisp, tender and sweet............... 10 $20 \quad 60$

Crosby's Egyptian-An improved strain of the Egyptian Beet..........

Long Smooth Blood-An excellent late variety.................... I0 $20 \quad 60$

Bastian's Early_Deep red color; a popular variety............... $10 \quad 20 \quad 60$

Dewing's Blood Turnip-Best for general use : color blood red.........

Swiss Chard, Silver or Sea Kale Beet-Used as greens............

\section{Sugar Beets and Mangel Wurzel.}

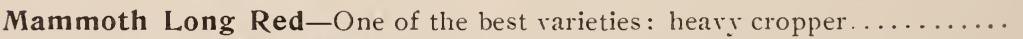

Norbiton Giant Long Red-This is a valuable variety for deep soil.......

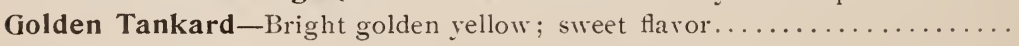

\section{Borecole, or Kale.}

Sow early in spring in prepared beds, covering the seed thinly and evenly, transplant in June, and treat in tlie same manner as for Cabbage. The following varieties are extremely hardy, and are best when touched by frost.

$$
\text { () } z \quad 1+L b \quad L b
$$

Dwarf Curled Kale-Used for early greens...................... 10 30 i 00

German Greens, or (Sprouts), Winter Kale-Sown in September, in drills one foot apart, and treat as spinach. 


\section{Broccoli.}

Nearly allied to the Cauliflower, but more hardy. The seed should be sown in May, in a seed bed and the plants afterwards set in rows about two and a half feet apart, leaving eighteen inches between the plants. It succeeds best in a moist and rather cool atmosphere.

Purple Cape-Heads greenish purple; hardy and popular variety

$$
\text { Pkt } \mathrm{Oz}
$$$$
\text { IO } 30
$$

\section{Brussels Sprouts.}

The plant grows two or three feet high, and produces from the side of the stalk numerous little sprouts one or two inches in diameter, resembling cabbages. Sow in hot-beds in March or April, and in the open ground in May. Transplant and cultirate like the cabbage.

$O z \quad 1 /+L b$

Improved Dwarf-The best for general use................... $20 \quad 65$

\section{Cabbage.}

For early crops sow in hot-bed in February and March. When the plants are four or five inches high, they should be transplanted in the open air as soon as the soil will admit, in row's two feet apart, and about fifteen inches from plant to plant. Late varieties are usually sown in the middle of Mav, and the plants are set out in July, at distances of three feet between the rows, and about twenty inches from plant to plant.

All Seasons-Early; heads large and solid...................... $20 \quad 65$

American Improved Savoy-Excellent sort for market gardeners......... $25 \quad 75$

Charleston Wakefield-Larger than the Jersey, but not quite as early...... $\quad 25 \quad 75$

Early Jersey Wakefield-Extra stock; the best and most profitable variety;

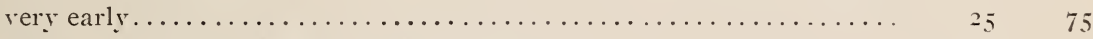

Early York-Very early; tender and excellent flavor................ $20 \quad 50$

Fottler's Improved Brunswick-The best early Drumhead, very large, and is equally valuable as a Winter Cabbage.................... $20 \quad 65$

Henderson's Early Summer-Extra stock: the best second early cabbage.. $\quad 20 \quad 70$

Large Late Drumhead-An excellent winter variety................. $20 \quad 6_{5}$

Marblehead Mammoth-A late variety: the largest of all cabbages........ $\quad 25 \quad 75$

Premium Flat Dutch-Large and excellent for winter.............. $20 \quad 60$

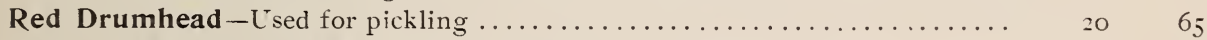

Stone Mason Drumhead-Standard variety; rery large solid heads....... $20 \quad 6_{5}$

Succession-A second early, with large solid heads................. $25 \quad 75$

Surehead-Best main crop cabbage for market or home use............ $20 \quad 6_{5}$

Winningstadt-A fine variety for general use................... $20 \quad 60$

Holland-Large, late, round, solicl heads; one of the best shippers and winter keepers in the market............................ $30 \ldots \ldots$

\section{Carrot.}

For early crop, sow as soon as the ground can be worked; they may be sown as late as the middie of June; the drills should be one inch deep and one foot apart, thinning out to three or four inches between the plants. Carrots do best in a deeply-tilled, sandy loom.

Early Scarlet Horn-A favorite sort; for early summer use............ $10 \quad 25$ So

Early French Forcing-The earliest variety grown, small, tender, fine quality $10 \quad 25$ So

St. Valery-An excellent variety for private gardens. Grorrs from ten to twelve inches long............................ 25 So

Guerande, or Oxheart-Stump-rooted; one of the most valuable varieties, either for family use or market: fine flaror and color: very productive Io 25 So

Danver's Half Long-Of excellent quality; yields the greatest bulk with the smallest length of root.......................... I0 25 So

Chantenay-A stump-rooted variety, having a large shoulder, very productive $10 \quad 25$ So

Improved Long Orange-Large variety; used for main crop............ 10 25 So

White Belgian-Large white root; extensively grown for stock feeding.... $10 \quad 20 \quad 50$ 


\section{Cauliflower.}

Cultivate as directed for Cabbage. In dry weather water liberally. Cauliflower like a cool, moist situation.

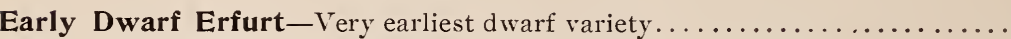
Pkt $\mathrm{Oz}$

Early Snowball-A very popular early variety; for family use or market $20 \$ 200$ gardeners

\section{Celery.}

Seed may be sown in the open ground in April. Sow about half an inch deep, and firmly press the soil, orer the seed. After the seed is up, keep carefully clear of weeds until the time of planting in June or July. After the ground has been well prepared, plant in rows from three to four feet apart, according to the variety, setting the plants about six inches apart, and pressing the soil firmly about the roots; the soil best suited for Celery is a rich, moist loam.

Paris=Golden Self=Blanching - True. The best celery for early market use ;

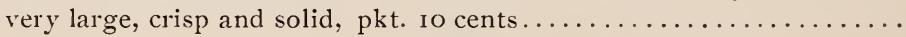

Giant Pascal-Of excellent flavor; very large and strong growing.........

Boston Market-True stock; the most popular variety known...........

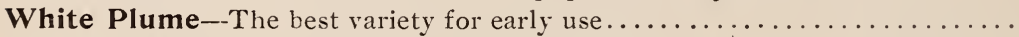

Pink Plume-Best of all the red or pink varieties; very crisp and fine flavor.

Celeriac, or Turnip Rooted-Grown exclusively for its roots, which are

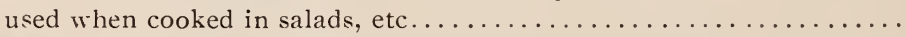

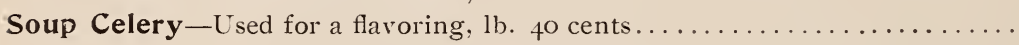
$40 \quad$ I 25

\section{Chervil.}

Curled Chervil-An aromatic, sweet herb. The young leaves are used in soups and salads. Sow thinly, in May, in drills half an inch deep;

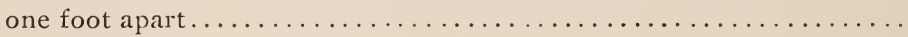

\section{Corn, Sweet.}

Plant for a succession of crops every three weeks, from April to July, in hills three feet apart each way, six seeds in a hill; cover about an inch; thin to three plants. Corn does best in a warm and rich soil.

Cory-A very early variety..

White Cory-Similar to the preceding, except the kernels are white........

Marblehead, Extra Early_Cob red and small; of excellent flaror.........

Early Minnesota-An eight-rowed early variety; of excellent quality........

Hickox Improved-An excellent second early; very sweet and productive....

Early Crosby_Extra stock; an excellent second carly variety...........

Potter's Excelsior, or Squantum-Twelve-rowed; one of the finest main

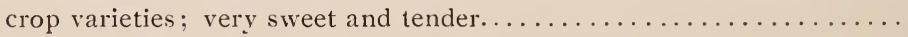

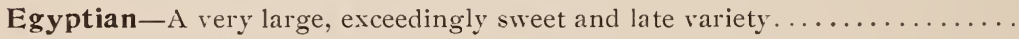

Mammoth Sweet-Late variety; ears larger than any other sorts...........

Perry's Hybrid-An early twelve-rowed variety; very sweet and tender.....

Champion-Medium early; ears large; splendid variety for market gardeners.

Black Mexican-One of the most desirable for family use; very tender

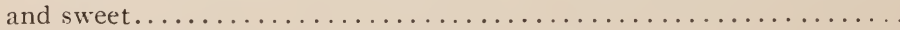

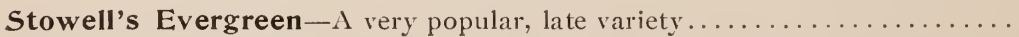

Rhode Island Sweet $-A$ medium late variety; very sweet and tender....... 


\section{Fodder and Field Corn.}

Sweet Fodder-For cutting green and feeding to stock............... $50 \quad \$ 150$

White Ensilage-Excellent for fodder and ensilaging purposes........... $30 \quad$ I

Rhode Island White Cap-A well-known, small, white, flint variety....... $60 \quad 2$ oo

Leaming Improved-Very early; one of the best deep grain sorts, small red

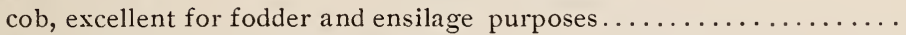

Angel of Midnight-Early yellow field corn; very productive.............

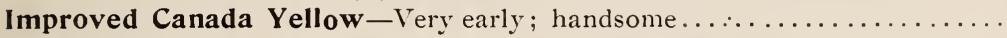

$30 \quad 100$

60200

60200

Longfellow-One of the best for main crop; very long ears..............

60200

\section{Corn Salad or Fetticus.}

Used as a salad. Is sown in early spring, in rows a foot apart, and is fit for use in six or eight weeks from the time of sowing.

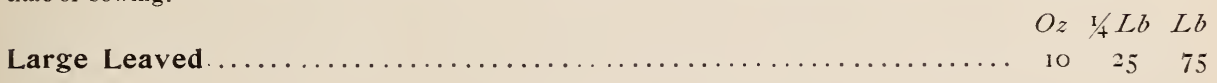

\section{Cress, or Pepper Grass.}

A well-known pungent salad; cover very slightly, sow at frequent interrals to keep up a succession; to be used before the flowers appear.

Extra Curled-Very fine; may be cut two or three times............. ro 20 50

Water Cress-Hardy, perennial aquatic plant................ 40 I $25+$ OO

\section{Cucumber.}

Cucumbers succeed best in warm, rich, sandy loam ground. Plant when all danger of frost is past, in hills about four feet apart each way, the hills should be previously prepared by mixing thoroughly with the soil of each a shovelful of well rotted manure; sow for pickling from the middle of June to the middle of July.

Improved White Spine-One of the best varieties for table use. Flesh tender and of excellent flavor...................... 10 2560

White Spine Forcing-A special strain for cultivation under glass. Fruit grows rery even in size; color, dark green $\ldots \ldots \ldots \ldots \ldots \ldots \ldots \ldots \ldots$ 30 100400

Early Russian-The earliest in cultivation; small and productive........ $10 \quad 25 \quad 60$

Early Cluster-Length about five inches; tender and productive.........

Early Frame-A standard early sort of medium size ............... Io $25 \quad 60$

Boston Pickling-True stock; the best variety for pickling.......... Io $25 \quad 60$

White Pearl-Very productive, and fine flavor; fruit pearly white....... $10 \quad 25 \quad 75$

Green Prolific_Excellent for summer use and for pickling...........

Long Green-Ten to twelve inches in length; dark green............ 10 $25 \quad 60$

West India Gherkin-Small, oval shaped, for pickling............ Io 30 I oo

Nichol's Medium-Green-Unequalled for forcing or for pickling......... Io $25 \quad 60$

Everbearing-Small sized, very early, and enormously productive........ $10 \quad 25 \quad 60$

Japanese Climbing-New. Can be grown either as an ordinary ridge cucumber, or as a climber........................... $10 \quad 25 \quad 75$

\section{Dandelion.}

Sow in May or June in drills a foot apart, press the earth firmly over the seed, cultivate during summer, cover lightly with straw during winter, and the following spring the leaves will be fit to cut. The roots when dried and roasted are often employed as a substitute for coffee.

Improved Broad=Leaved-Pkt. to cents................. 


\section{Egg-Plant.}

The seed should be sown in hot beds the first week in April. Plant out about June ist, about two and a half feet apart. The Egg-Plant will thrive well in any good garden soil.

New York Improved-Extra large and choice, fine flavor........ Pkt $O z \quad 1 / 4 \mathrm{Lb}$

\section{Endive.}

Sow in drills one foot apart, thin out to ten inches apart, blanch when the leaves are about nine inches long, by drawing them together and tying them carefully.

Green Curled-Very hardy; leaves dark green; tender.. Oz $1 / 4 \mathrm{Lb} \quad \mathrm{Lb}$

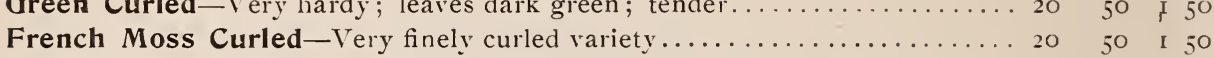

Batavian-Broad-leaved. Leares long and broad, chietly used in soups.....20 50 I 50

\section{Kohl Rabi.}

The seeds of this plant may be sown at the same period as the Swedish or Rutabaga Turnip, and may be cultivated in the same way, remembering to leave the chief part of the stems uncovered by the earth. The bulbs may be kept sound and nutritious until late in the spring, even later than those of 'Turnips.

Early White Vienna-The best variety...................... 2060200

Early Purple Vienna-Later than the white.................. 2060200

\section{Leek.}

The Leek is very hardy and easily cultivated. Sow in April in drills one foot apart, and transplant in July into rows fifteen inches apart, and six inclies from each other in the rows; the soil should be rich but not fresh inanured. Large Flag-Large, strong growing variety, broad leaves; very hardy $\ldots \ldots 20 \quad 60$ I 75

\section{Lettuce.}

The earliest sowing may be made in February or March, under glass, with slight heat. For later supplies, sow in the open ground as the season will permit, thin out well and set in rows two feet apart, and a foot between the plants. Lettuce requires good ground and abundant moisture.

Forcing Tennisball, White=Seeded - Selected stock. This lettuce is

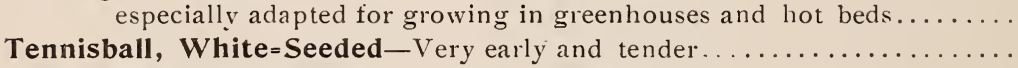

$O z \quad 1 / 4 L b$

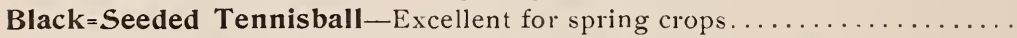

Boston Market - Hardy and crisp; the earliest heading variety...........

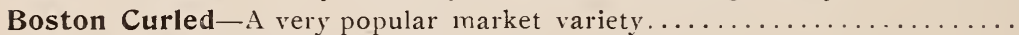

All the Year Round-An excellent summer lettuce...................

Henderson's New York-Large and solid head; tender and of excellent flavor

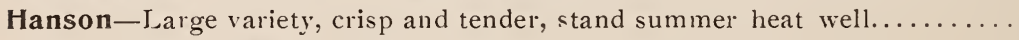

Early Curled Silesia-An early variety of very strong growth...........

Early Curled Simpson-Excellent sort for forcing, or early out-door culture

Black=Seeded Simpson-An improved variety of the ordinary Curled

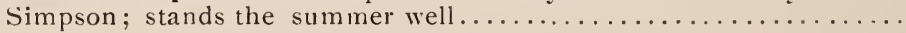

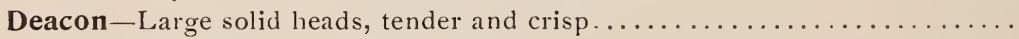

Paris White Cos-An upright variety, with long narrow leaves; requires

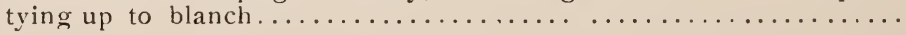

Tomhannock-Leaves almost white, crisp and tender; edges of the outer

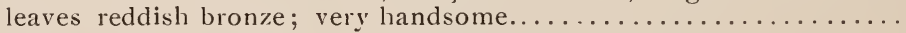

Brown Dutch - Very hardy; one of the best winter varieties............

Denver Market-For forcing or open gromnd culture; heads large and solid; leaves blistered like a savoy Cabbage: very crisp and tender.......

Belmont Forcing-For forcing in the greenhouse, larger than the Tennisball Sensation-Good for eitherforcing under glass or growing out of doors, solid

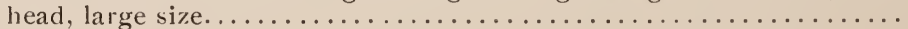




\section{Martynia.}

The seed pods are used for pickling, and should be gathered green while tender, sow in the open ground in April or May, and transplant tivo feet apart.

Martynia Proboscidea.

Plet $O z$

0530

\section{Melon-Musk.}

Prepare hills four to five feet apart each way, mix well with the soil in each hill a couple of shovelfuls of thoroughly rotted manure. When the weather has become warm, plant from twelve to fifteen seeds in each hill, afterwards thin out, leaving four good plants.

Emerald Gem-Early, small, flesh deep orange; very sweet........... $10 \quad 25 \quad$ So

Early Christina-Very choice; flesh yellow; early; one of the best...... IO $25 \quad 75$

Golden Netted Gem-One of the earliest, best and most prolific small melons. $10 \quad 25 \quad 75$

Montreal Green Nutmeg-Largest of the nutmeg varieties; flesh thick and

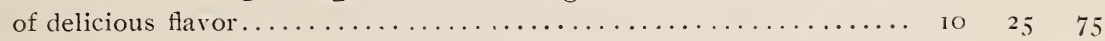

Jenny Lind-Flesh light green; small but very early.............. IO $25 \quad 70$

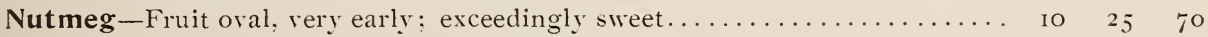

White Japan-Early cream white and fine flavored variety............ $10 \quad 25 \quad 75$

Long Yellow Musk-Deeply ribbed; flesh thick; early............ IO $25 \quad 70$

Miller's Cream-Flesh rich salmon; very thick and solid. . . . . . . . . $10 \quad 25 \quad 75$

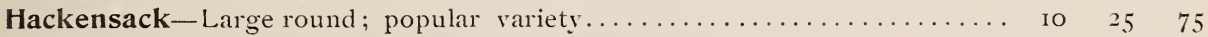

The Banquet_Medium-sized; beautifully netted : flesh rich salmon...... $10 \quad 25 \quad 75$

Rocky Ford-Flesh green, medium size, oval shape.............. $20 \quad 602$ oo

Tip=Top-Yellow fleshed, very productive, firm and sweet.......... Io 25 So

\section{Melon-Water.}

Plant in hills as directed for Musk-Melons, and treat in all respects the same except that the hills should be about eight feet apart.

Phinney's Early-Very early and sweet; flesh deep red............. $10 \quad 20 \quad 60$

Mountain Sweet-One of the best; color dark green.............. $10.20 \quad 60$

Black Spanish-Large; very dark green; flesh deep red; sugary......... I0 $20 \quad 60$

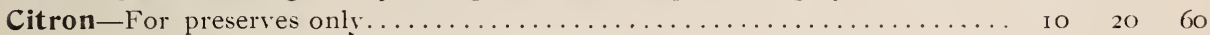

Cuban Queen -Large variety ; flesh bright scarlet, crisp and sweet........ I0 2060

Klob's Gem-Very large size; nearly round; dark green color.......... I0 $20 \quad 60$

Ice Cream-One of the earliest; nearly round; of pale green color; flesh scarlet, solid, crisp, and very sweet....................... IO $20 \quad 60$

Cole's Early-Medium size; flesh bright red; excellent quality.......... $10 \quad 20 \quad 60$

\section{Mushroom.}

Mushrooms may be grown in a warm cellar or shed in winter, or in the open air in summer. Take partially dry fresh horse manure and lay it in a heap to ferment; turn and mix it well every few days, and when well and equally fermented, which will be in from ten to fifteen days, it may be made into a bed four feet wide and about two feet deep, mixing it well together and beating or treading it firmly. As soon as the temperature of the bed falls from 75 to 50 degrees, the spawn may be inserted in pieces about the size of a walnut, about two inches deep and six inches apart. Cover with loamy soil about two inches deep and beat it down evenly and firmly. Finish off witl a covering of clean straw or hay about a foot thick. Water when necessary with luke-warm water, and expect mushrooms in from four to six weeks.

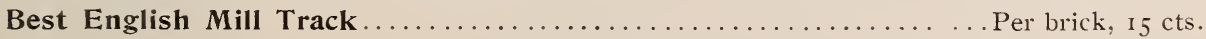

\section{Mustard.}

Sow in shallow drills a foot apart. The young leaves are used for salads and the seeds for flavoring.

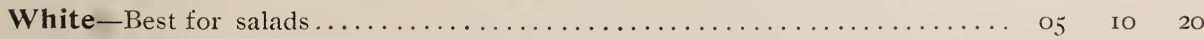

Brown-More pungent in flaror than the white................. 05 IO 20 


\section{Nasturtium.}

The seeds while young and succulent are pickled and used as capers. Sow the seeds in drills one inch deep. the tall grown by the side of a fence, or supported by a trellis.

Tall Mixed

$\mathrm{Oz} \quad 1 / \mathrm{Lb} \quad \mathrm{Lb}$

Dwarf Mixed

$40 \quad$ I 25

\section{Okra or Gumbo.}

Sow early in May, in drills two inches deep, setting the plants from two to three feet apart.

Dwarf Green-The very best variety for general cultivation............ Io 30 I 00

\section{Onion.}

The Onion thrives best in a rather stong, deep, rich, loamy soil and unlike most regetables succeeds well when cultivated on the same ground for successive years. Sow in drills one foot apart, and corer about a quarter of an inch deep, pressed down with the back of a spade. Our stock is all grown from choice selected bulbs, under our own supervision, therefore parties using our seed will be sure of getting new choice seed of the best quality.

Danver's Yellow-Extra selected; best for general use............ $25 \quad 75 \quad 2 \quad 50$

Early Large Red-Very fine early sort; handsome shape............. $25 \quad 75 \quad 2 \quad 50$

Large Red Weathersfield-Grows large and keeps well; deep red....... $25 \quad 75 \quad 2 \quad 50$

Red Globe-Earliest, most productive; handsomest of the red sort........ $25 \quad 75 \quad 2 \quad 50$

White Globe-An excellent keeper of mild flaror................ $25 \quad S_{5} \quad 2 \quad 75$

White Portugal-One of the best for table use; flavor mild............ $25 \quad S_{5} \quad 2 \quad 75$

Prizetaker-Large, pale yellow onion; flesh white; mild flavor......... $25 \quad 75 \quad 250$

\section{Onion Sets. (Prices Variable.)}

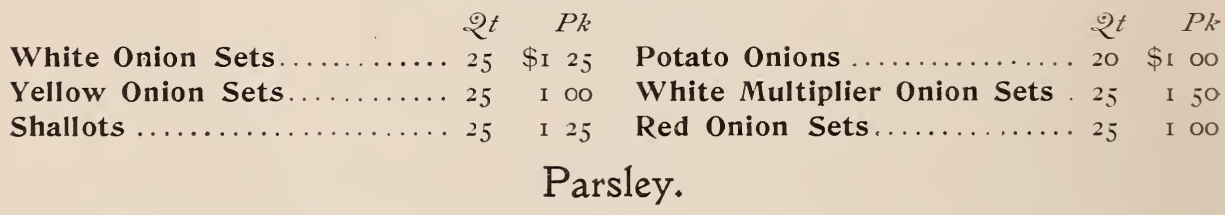

Sow thickly in drills a foot apart and half an inch decp early in the spring, having soaked the seed in tepid water a few hours.

Oz $\quad 1 / L b \quad L b$

Champion Moss Curled-Fine and unsurpassed for garnishing.......... I0 $25 \quad 75$

New Fern Leaved-Very Ornamental ; valuable for table decoration....... ro $30 \quad 90$

\section{Parsnip.}

Sow as early as possible, half an inch deep, and press the soil firmly over the seed, succeeds best in a rich, sandy loam.

Hollow $=$ Crown or Long Smooth - The standard sort for general use..... io $20 \quad 50$

\section{Peas-Extra Early Varieties.}

For early Peas, the soil shou!d be light, warm and sheltered, but for general crop, a moderately heary soil with liberal dressing of phosphate is better. Aroid fresh manure and wet or mucky soil, they making the vines tall and rank. Plant in drill three or four inches deep, the dwarf varieties two and a half feet and the tall ones three to four feet apart.

Earliest of All or Alaska-A superior blue seeded variety; very early and productive; height 2 1-2 feet.......................... $25 \quad$ I 25

Bliss's American Wonder-Stands unrivalled; height ro to 15 inches...... 25 I 50

Nott's Excelsior-A grand new drawf wrinkled pea of superb quality; very prolific: height about ${ }_{5} 5$ inches........................ $25 \quad$ I 50 
Dwarf Telephone-Peas large; extra quality; height is inches............ Johnson's First and Best-First in the market; height $2 \mathrm{I}-2$ feet.......... Daniel O'Rourke, Improved-Early and popular variety; height 2 I-2 feet.. Premium Gem-Early; very prolific; wrinkled; height is inches......... Pride of the Market-Very productive; pods large and handsome; finest

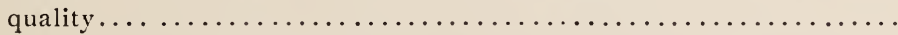

\section{Peas-Second Early and Later Varieties.}

Paragon-New, medium late; double podded; very productive; excellent

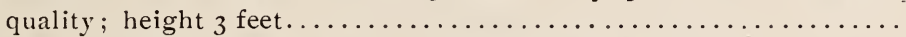

McLean's Advancer-Dwarf, green wrinkled; height 2 I-2 feet..........

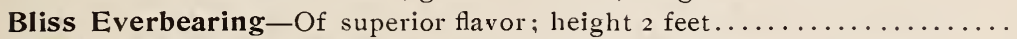
Horsford's Market Garden-Very prolific; superior quality; height 2 feet. Champion of England-Quality unsurpassed; height 5 feet............ American Champion-One of the largest of Peas; enormously productive;

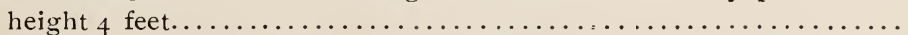

Stratagem-A new dwarf wrinkled pea; heavy bearer; height 2 feet....... Yorkshire Hero-Very productive; delicious flavor; height 2 I-2 feet....... Juno-Large, straight pods, fine quality; very productive; height 2 feet.

Heroine-Medium early, green wrinkled pea; quality unsurpassed; 2 I-2 feet.

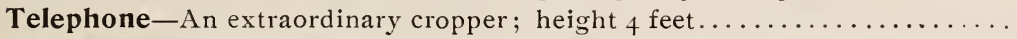
Black=Eyed Marrowfat-Excellent for garden or field; height 4 feet.

\section{Pepper.}

Sow the seed in March or April, in a hot-bed, and transplant to the open ground as soon as the weather is quite warm, in rows about twenty inches apart, and fifteen inches apart in the rows. A warm, sandy loam is best.

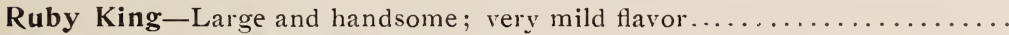
$O z \quad 1 / L b b$

Large Bell, or Bull Nose-Early, sweet, and of a pleasant flavor......... 25 So Squash-Brilliant red; medium size; excellent for pickling............

Sweet Mountain-Similar to the "Bull Nose," but larger, sweeter, and of

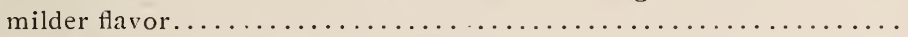

Long Red Cayenne-Pods long, cone shaped and intensely red..........

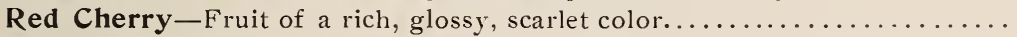
Chili-Very small, bright red; cone-shaped best for pepper sauce..........

\section{Pumpkin.}

Pumpkins are now principally cultivated for agricultural purposes. They are usually planted in fields of Corn or Potatoes, but may profitably be raised in fields by themselves. Sow first of May, in hills eight feet apart.

Oz $\quad 1 / 4 \mathrm{Lb} \mathrm{Lb}$

Yellow Sugar-Very sweet; an excellent table sort.............. 10 $20 \quad 50$

Connecticut Field-Used for feeding stock.................. $0_{5}$ 10 25

Large Cheese-Flat; one of the best varieties for family use......... IO ${ }^{\circ} 25 \quad 75$

\section{Potatoes.}

\section{(Market Prices.)}

Plant in hills or rows two feet wide and one foot apart in the rows. Cover with about two inches of soil, and begin to cultivate when the plants are well up.

Our stock of potatoes is carefully selected direct from the famous Aroostook County, Maine, and comprises the following well known varieties: 


\section{Potatoes-Continued.}

$\begin{array}{lll}\text { Clark's No. 1. } & \text { Early Rose. } & \text { White Elephant. } \\ \text { New Queen. } & \text { Beauty of Hebron. } & \text { Pearl of Savoy. } \\ \text { Carman No. 3. } & \text { Early Norther. } & \text { XX Early. }\end{array}$

Our stock has been grown from selected seed expressly for seed purposes.

XX Early-This is the earliest potato grown: is a good yielder, free from rot, and is not excelled by any potato for table use; it resembles the Early Rose in color. Produced last season as high as 300 bushels per acre.

\section{Radish.}

Radishes require a light, rich, sandy soil. For an early supply sow in a hot-bed in February, care being taken to give plenty of ventilation. For a successive supply, sow from the middle of March until September, at intervals of two or three weeks.

Long Scarlet Short Top-Standard variety for home and market use..... I0 $20 \quad 50$

Scarlet Turnip-A deep scarlet; early: fine flavor.............. 10 20 50

Non Plus Ultra - The earliest forcing radish; round, bright scarlet, short top:

fine flaror: very quick growth........................ 10 $20 \quad 60$

Round Scarlet White=Tipped-Very quick growth and excellent flaror..... I0 $20 \quad 60$

Wood's Early Frame-Suitable for forcing and early market garden....... I0 20 50

French Breakfast-Scarlet, white tips, oval: quick growing........... I0 20 50

Olive Shaped Scarlet-A good summer variety................. I0 20 50

Olive Shaped White-Same as the preceding, except in color.......... 10 20 50

White Strasburg-One of the best of the large summer sorts; roots long and tapering; skin and flesh pure white; tender, crisp, and fine flaror. IO $20 \quad 50$

Black Spanish-Roots oblong; very hardy; for winter use........... $10 \quad 20 \quad 50$

Chartier-A new variety; long; almost white; very tender............. $10 \quad 20 \quad 50$

Early Scarlet Globe-Distinct in shape; brilliant color; fine for forcing or

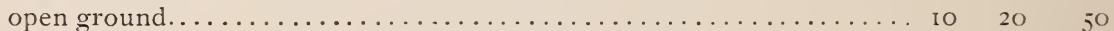

Rose China Winter-Bright rose color; excellent for winter.......... 10 o 20 50

\section{Spinach.}

For summer use, sow early in March, in drills fifteen inches apart, and for succession at intervals of at fortnight. For winter use, sow late in August. The scil should be heavily manured and deeply trenched.

Round Thick Leaved-The best for spring or fall sowing........... $0_{5}$ IO 30

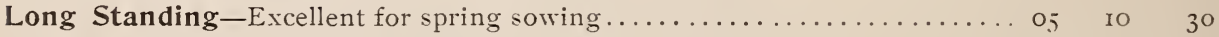

Prickly - The hardiest sort; generally used for fall sowing............ o5 $_{5}$ IO 30

Bloomsdale-Savoy leaved; for sowing in the fall for early spring use...... 05 I0 30

New Zealand-Entirely distinct variety: produces a large quantity of leaves;

for summer use. ........................... $10 \quad 3090$

\section{Salsify, or Oyster Plant.}

The Salsify has a long, white tapering root resembling a small Parsnip; when properly cooked it has the flavor of an Oyster, and is a good substitute. Sow early, in drills fifteen inches apart; cover the seeds an inch and a half deep.

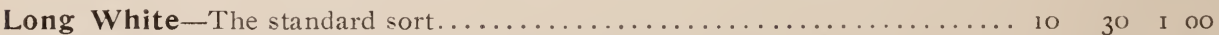

Sandwich Island-Grows to a large size; very mild Havor........... I5 50 I 50 


\section{Squash.}

The Squash is a very tender vegetable, sensitive of cold, and cannot in our climate be planted before the uniddle of May. Plant in rich soil, in hills prepared similar to those for Cucumbers. All sorts thinned to not over three plants to a hill.

Yellow Bush Scalloped-Much like the white; fruit yellow............ ro $20 \quad 60$

Early Summer Crookneck-The best for summer use............. Io $20 \quad 60$

Boston Marrow-A standard winter variety; a good keeper............. to $20 \quad 60$

American Turban - A late variety; flesh orange yellow.............. I0 $20 \quad 60$

Hubbard-The favorite winter squash; sweet and fine grained.......... I0 $20 \quad 60$

Warted Hubbard-Larger than the above....................... 10 o $20 \quad 60$

Marblehead-Flesh lighter in color than the Hubbard; very sweet, dry and

delicious flavor................................ to $20 \quad 60$

Essex Hybrid-Very rich flavored; fine grained; rapid in growth; early... $10 \quad 20 \quad 60$

Winter Crookneck-Sweet and fine flavored; a good keeper............ I0 $20 \quad 60$

Fordhoak-Fine-grained, sweet, hardy and productive..............

Giant Summer Crookneck-Double the size of the ordinary Crookneck... 10 $20 \quad 60$

Mammoth Chili-Rich orange yellow color; growing to an enormous size... I 5 50 I 50

\section{Tobacco.}

Sow early as possible when danger of frost is over, in seed bed and cover lightly When the plants are six inches high transplant into rows six feet apart each way and cultivate thoroughly.

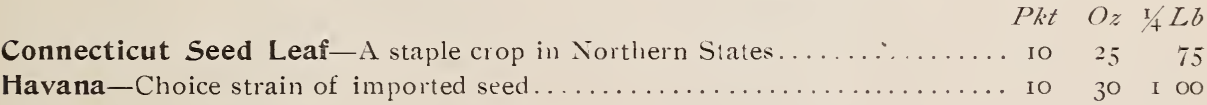

\section{Tomato.}

The seed should be sown in a hot bed about the first week in March, in drills five inches apart and half an inch deep. When the plants are about two inches high, set out in boxes, three inches deep, four inches apart, in another hot-bed, or pot singly. If transplanted a second time will be stocky and branching. When the weather has become mild, transplant into warm, light, rich soil, four feet apart.

Acme-One of the earliest; perfectly smooth; color, salmon red........ $05 \quad 25 \quad 75$

Aristocrat-New; resembles Dwarf Champion in growth; fruit, rich, glossy red; very desirable for forcing under glass............... 050 I

Canada Victor-Early medium sized variety; rich flavor............. $05 \quad 25 \quad 75$

Dwarf Champion-A new and distinct variety; fruit early; medium size; resembling the Acme in size and color.................... $05 \quad 25 \quad 75$

Atlantic Prize-Very early; solid; smooth; excellent quality.......... $05 \quad 2.5 \quad 75$

Golden Queen-The finest yellow tomato in cultivation .............. $05 \quad 25 \quad 75$

Livingston's Beauty-Color, glossy crimson; smooth, firm and solid..... $05 \quad 25 \quad 75$

Livingston's Favorite-Is one of the largest and most perfect shaped varieties; ripens evenly; good flavor; flesh solid and smooth; rery

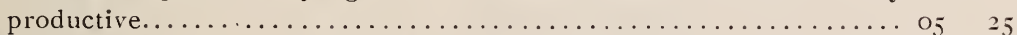

Livingston's Perfection-Very large and early; perfectly smooth; blood red

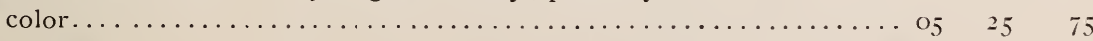

Lorillard-New; one of the finest varieties for forcing under glass as well as for out-door culture; very early and of fine flavor............. $0_{5} \quad 25 \quad 75$

Mayflower-Early, large, smooth and glossy red; very productive........ $05 \quad 25 \quad 75$

Mikado-Very large variety ; color purplish red; very solid........... $05 \quad 25 \quad 75$

Paragon-Larger than the Perfection, but not quite as early; bright red color; smooth, solid, and of excellent flavor; very productive............ 


\section{Tomato-Continued.}

Peach-Entirely different from any other tomato and resembles a peach in size,

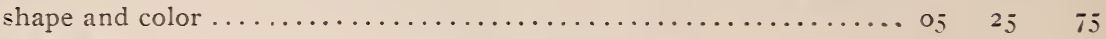

Ponderosa-Very large and smooth: color, dark, rich crimson $\ldots \ldots \ldots \ldots \ldots$ o5 30 I 0

Red Cherry-Small. round fruit: used for preserves............... $05 \quad 25 \quad 75$

Stone-One of the best; fruit very large, bright scarlet, very smooth: ripens

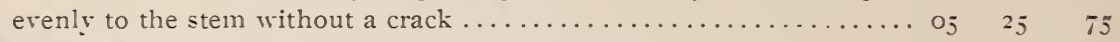

Strawberry -Strawberry-like flaror: excellent for preserves...........

Trophy_Fruit very large: solid and excellent for main crop........... $0 ; \quad 25 \quad 75$

Yellow Plum-Used for preserves, also for pickling ............... $05 \quad 25,75$

\section{Turnip.}

For summer use, sow eariy in the spring in drills, and thin out to eight inches. For fall and winter, sow from July to September. Rutabagas should be sown in June or early in July, in drills eighteen inches apart; thin out when large enough, six to nine inches apart in the drill, according to size.

Early Flat Dutch_White, of quick growth, for spring or fall.......... 10 20 io

Extra Early Purple Top Munich-One of the earliest of the flat turnips.

with a bright purplish red top: excellent quality.............. I0 $20 \quad 50$

Extra Early Purple Top Milan-The earliest of all; bulb white, flat, of medium size: one of the sweetest and finest flavored of summer sorts.. IO $\quad 25 \quad 75$

Golden Ball-Medium size: flesh, firm and sweet: unsurpassed for table use.. Io $20 \quad 50$

Early Snowball-Pure white: medium size and fine quality........... 10 $20 \quad 50$

Red Top Strap Leaf-The popular variety for early use............. 10 $20 \quad 50$

White Egg-Smooth and nearly egg-shaped: of rapid growth and fine quality:

excellent fall variety.............................. 50

Cow Horn-Flesh white, fine grained, sweet: excellent for table use....... 10 $20 \quad$ jo

Yellow Aberdeen-Very hardy and productive; globe shaped, with purple top: good keeping qualities......................... I0 $20 \quad 50$

White Rock or French-Flesh white, solid, mild and sweet: excellent for

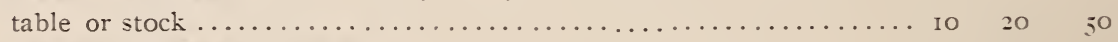

Budlong Improved White Rock...................... 10 20 ;0

Sweet German-Flesh pure white. fine grained; sweet and mild......... I0 $20 \quad 50$

Improved American Purple Top-Very hardy and productive; flesh yellow,

solid, sweet and of good flaror....................... $10 \quad 20 \quad 50$

\section{Sweet, Pot and Medicinal Herbs.}

\begin{tabular}{|c|c|}
\hline$P h t$ & $O z$ \\
\hline Lavender, Perennial....... o5 & 20 \\
\hline Rosemary, Perennicl...... o5 & to \\
\hline Marjoram, Sweet, Aunmm?.. o5 & 25 \\
\hline Sage, Annurul............. o5 & 20 \\
\hline Thyme, Perennirl......... o5 & \\
\hline
\end{tabular}

Pht $\mathrm{Oz}$

Anise, Annukl........... $0_{5}$ is

Basil, sweet, Annual... . . 0520

Dill, Biennial ............. 0515

Caraway, Biennial......... 0510

Summer Savory, Annuril ... 0520
Horehound, Perennial Pht $\mathrm{Oz}$ .... $05 \quad 40$ Wormwood, Perennial ..... o5 30 Éennel, Perennial.......... o5 15 Hyssop, Perennial......... 10 to

\section{Bird Seeds.}

Qt Busle

Canary Sicily, Recleaned.. ${ }_{15} \$ 3$ 50 Hemp Russian, Recleaned so 2 o Rape German........... ${ }_{15} 300$
Qt Bush

Millet............... 10 150

Sunflower............. of 20

Unhulled Rice.......... 15 300
Rejected Wheat..per roo lbs., \$1 i5 Mixed Bird Seed...per lb. box, Ioc. Maw, Blwe Poppy...... per lb. 2oc. 


\section{Vegetable Plants and Roots.}

\begin{tabular}{|c|c|c|c|c|c|c|}
\hline Artichokes- & $2 t$ & $P k$ & Lettuce Plants- & Doz & & \\
\hline Jerusalem............... & 20 & \$I OO & Curled Simpson ........... & 15 & $\$ I$ & \\
\hline is Roots- & Doz & 100 & son $\ldots \ldots \ldots \ldots \ldots \ldots$ & $\mathrm{I}_{5}$ & I & \\
\hline r's Colossal......... & 20 & 75 & D.11 & 15 & I & \\
\hline & & I 00 & & I5 & & \\
\hline abba & & & Melons- & & & \\
\hline akefield...... & 15 & 60 & ots. & I OO & & \\
\hline ...... & 15 & 60 & No & & & \\
\hline$\ldots \ldots \ldots$ & 15 & 60 & Onion $\mathrm{S}$ & & & \\
\hline$\ldots \ldots \ldots$ & $\mathrm{I}_{5}$ & 60 & Pepper & & & \\
\hline aulif & & & $\mathrm{Be}$ & 20 & & \\
\hline ball $\ldots \ldots \ldots \ldots$ & 25 & I 50 & $\ldots \ldots \ldots$ & 20 & & \\
\hline -Blanching...... & 20 & I 25 & b $\mathrm{Rc}$ & & & \\
\hline$\ldots \ldots \ldots$ & 20 & I 25 & & I $\mathrm{OO}$ & & \\
\hline & 20 & I 25 & & 500 & & \\
\hline$\ldots \ldots \ldots$ & 20 & I 25 & Sage . & 20 & & \\
\hline hive & & & & $5^{\circ}$ & & \\
\hline per bunch.......... & I $\mathrm{OO}$ & & $\begin{array}{r}\text { Toma } \\
\mathrm{A}\end{array}$ & 20 & & \\
\hline & I $O O$ & 700 & 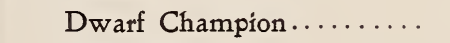 & 20 & & \\
\hline Egg Pla & & & $\ldots \ldots \ldots \ldots$ & 20 & & \\
\hline New Yo & I $\mathrm{OO}$ & 700 & $\mathrm{~m} \ldots$ & 20 & & \\
\hline 15 & & & & 20 & & \\
\hline Small sets. & 15 & $5^{\circ}$ & Plum and Pear............ & 30 & & \\
\hline
\end{tabular}

\section{Seed Grain, Etc.}

\section{Prices Variable. Subject to Market Fluctuations.}

Barley-Clean sample........... \$r oo

Buckwheat, Common..... . . ..... I oo

Oats, Welcome.............. \$

\section{“Japanese-A very pro-}

lific variety, yielding more than any

other ................... I 50 Rye, Spring-Extra selected....... I $5^{0}$ Rye, Winter-Extra selected....... I oo Flax $=$ Seed $\ldots \ldots \ldots \ldots \ldots \ldots L b$ Io

“ American Triumph.......... I OO

“ Common ................ 50

Peas, White Canada-Largely grown for stock; should be mixed with oats.................. I 25

Tares, or Spring Vitches-Usually

sown with oats........... 250

\section{Lawn Grass Seed.}

\section{Mixture for Lawns, Tennis Courts, Croquet Grounds, Etc.}

There is nothing more beautiful and pleasing to the eye than a well-kept lawn, with its close, velvety turf. To insure this the principal object is to use good seed. For this purpose we recommend our "Park" Lawn Grass Mixture, which is composed of dwarf and close growing grasses, and best adapted to produce a fine, velvety lawn. The seed may be sown either in spring or fall. Four bushels of seed is required per acre.

Per quart, 20 cents; 4 quarts, 60 cents; peck, $\$ 1.00 ;$ bushel, $\$ 3.50$. 


\section{Grass Seed for the Farm and Lawn.}

\section{Prices Subject to Variations. Special Prices for Large Quantities.}

Crested Dog's Tail. (Cynosurus Cristatus.) An excellent grass for hard, dry soils, valuable for pastures and lawns. Per lb. 4oc.

Golden Millet. Of great value as an annual hay and fodder crop. Market Price.

Hard Fescue. (Festuca Duriuscula.) One of the most desirable dwarf grasses, excellent for dry soils. Per lb. $20 \mathrm{c}$.

Hungarian Grass. (Panicnm Germanicnm.) An annual forage plant of great value. One of the best plants for green fodder, ensilaging or hay. It will grow in any ordinary soil. Withstands drought well. Market Price.

Italian Rye Grass. (Lolium Italicum.) Thrives in almost any soil and vields early and abundant crops. Per lb. I5 c.

Kentucky Blue. (Poa Pratensis.) An early grass of great value, well known and extensively grown in all parts of the country. For pastures and lawns it has no superior. Per 1b. 20c.

Meadow Fescue. (Festuca Pratensis.) A valuable grass for permanent pastures, very productive and nutritious. Per lb. 2oc.

Orchard Grass. (Dactylis Glomerata.) One of the best grasses in cultivation. It is also one of the earliest. Yields immense crops and is excellent for pasture or hay, and for growing in shady places. Per lb. 2oc.

Red Top. (Agrostis Vulgaris.) A valuable, permanent grass, as a mixture in meadows, pastures, or lawns, growing well upon almost any soil. Narket price.

Red Top, Fancy Recleaned Seed. Free from chaff. Market price.

Rhode Island Bent. (Agrostis Cimina.) One of the best grasses for pastures or lawns. Per 1b. $25 \mathrm{c}$.

Rough Stalked Meadow. (Poa Trivialis.) Is one of the best of our meadow grasses. Produces an abundant crop of highly nutritious herbage, valuable for either moist, rich soils and sheltered situations. Per lb. $30 \mathrm{c}$.

Sweet Vernal, Perennial. (Anthoxanthum Odoratum.) It is one of the first grasses to appear in spring and remains green late in the autumn. Useful to mix with other grasses for pastures and lawns. Emits an agreeable odor when cut for hay. Per lb. $45 \mathrm{c}$.

Timothy. (Phleum pratense.) A variety well known and highly appreciated. Thrives best upon rich, heary soils, upon which it is quite permanent, and produces very heary crops. Market price.

Tall Meadow Oat. (Avena elatior.) An early grass much relished by stock, and producing an abundance of foliage; recommended as one of the best pasture grasses. Per 1b. 2.jc.

Wood Meadow. (Poa Nemoralis.) This grass is well adapted for growing in moist and shady portions of lawns and pastures. Per $1 \mathrm{~b} .35 \mathrm{c}$.

\section{Clovers.}

Alfalfa or Lucerne. (Medicago Sativa.) A deep rich soil is best adapted to the cultivation of this plant. In such, several crops are produced in a season. Per $1 \mathrm{~b} .{ }_{5} \mathrm{c}$.

Red Clover Medium. (Trifolium pratense.) The common red clover in general cultivation. Market price.

White Clover. (Trifolium repens.) Valuable for permanent pastures and is also used with lawn grass. Per 1b. 2oc.

Alsike or Swedish. (Trifolium Hybridum.) Valuable for hay or pasturage. Thrives well in cold, wet and stiff soils. Per lb. $15 \mathrm{c}$.

Crimson or Italian Clover. (Trifolium Incarnatum.) An annual variety with long blossoms of a deep red color. Excellent for soiling. Per lb. soc. 


\section{GENERAL LIST}

\section{..... \\ FLOWER

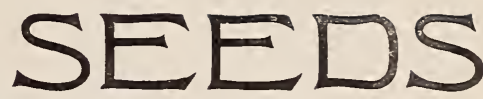 \\ $* * *$

\author{
All Flower Seeds are Sent Free by Mail on Receipt of Price. \\ The Smallest Quantity of Flower Seeds Sold by \\ Weight is Ten Cents Value.
}

Abutilon-Decorative shrubs with beautiful bell-shaped flowers, choice mixed.......05 Acroclinium-A beautiful everlasting flower, valuable for winter bouquets, annual.

Album-Single, pure white, I ft......... 55 Roseum-Bright rose, I ft............ 55 Adonis-Handsome and showy Howers, remaining a long time in flower, annual.

Aestivalis-(Flos Adonis.) Scarlet, I ft...05

Ageratum-Fine plants for massing outside, also for winter blooming in the house.

Imperial-Dwarf, blue, $3 / 4 \mathrm{ft} \ldots \ldots \ldots \ldots \mathrm{o}_{5}$ " -Dwarf, white, $3 / 4 \mathrm{ft} \ldots \ldots \ldots \ldots .5$

Mexicanum-Blue, $I_{1 / 2} \mathrm{ft} \ldots \ldots \ldots \ldots \ldots 0_{5}$ " Album- White, I $1 / 2 \mathrm{ft} \ldots \ldots .05$

Agrostemma-Free flowering and attractive border plants.

Coeli Rosea-(Rose of Heaven). Annual,

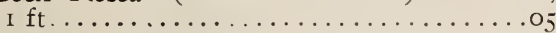

Aloysia Citriodora-(Lemon scented Verbena). Tender perennial............ Alyssum-Free flowering plants, serviceable for beds, borders or rock work.

Maritimum-(Sweet Alyssuin). Fragrant white, annual, I ft.. oz. $30 \ldots \ldots \ldots \ldots \ldots$. Benthami Compactum-Dwart, compact growth, annual, $1 / 2 \mathrm{ft} \ldots \ldots \ldots \ldots \ldots 0_{5}$ Saxatile Compactum-Bright yellow flowers; perennial, $3 / 4 \mathrm{ft} \ldots \ldots \ldots \ldots \ldots \ldots \ldots \ldots$

Amaranthus - Ornamental foliage plants, invaluable for bedding.

Bicolor Ruber-sicarlet and orange, $3 \mathrm{ft}$.

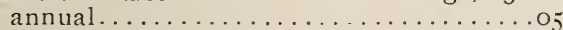
Tricolor-(Joseph's Coat). Foliage red, yellow and green, $3 \mathrm{ft} \ldots \ldots \ldots \ldots \ldots . . . .65$

Ammobium - Alatum Grandiflorum - Pure white, everlasting flowers, valuable for winter bouquets, annual, $2 \mathrm{ft} \ldots . . . \ldots . \mathrm{o}_{5}$

Ampelopsis-Veitchi-(Japanese or Boston Ivy). A beautiful clinging vine, easily raised from seed, perfectly hardy, oz. 35.05

Anagallis-Grandiflora-Dwarf, excellent for borders, baskets and rock work. Mixed sorts. annual....................
Anemone-Coronaria-Very beautiful spring flowers, and easily grown. Mixed colors, perennial. $1 / 2 \mathrm{ft} \ldots \ldots \ldots \ldots \ldots \ldots \ldots$

Antirrhinum - (Snapdragon). Beautiful summer and autumn flowering plants, succeeds well in any drv, loamy soil, annual. Grandiflora Mixed-Choice large flowering sorts....................... White-Pure white................ IO Tom Thumb - Dwarf, mixed, beautiful

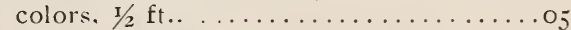

Tom Thumb-White............. o5 $_{5}$

Anchusa - Capensis - Azure blue flowers, splendid for bouquets, annual.......... 5

Aquilegia - (Columbine). An extremely showr and ornamental plant, perennial. Double mixed, finest sorts, $2 \mathrm{ft}$......... 55

Asparagus Sprengeri-Excellent for pots or hanging baskets.................... Plumosus Nanus-A greenhouse perennial climber.....................

Asperula-Azurea Setosa-Blue, beautiful and fragrant, grows well in shady places. annual, I ft...................... Odorat a-(Woodrutif). Flowers white; sweet-scented; excellent for rock work, perennial, I ft.................

Asters-One of the most popular garden favorites. The seeds should be sown early in the spring in a hot bed, and transplanted out doors when the weather is warm, about one foot apart. For best results asters should have a good rich soil and plenty of moisture, although they will do well in any ordinary garden soil; annuals.

Betteridge's-Improved quilled, mixed, $1 / 8$ oz., 20.................... 5

Branching, New White - Late flowering variety, with large, graceful. pure white flowers borne erect on very long stems. petals curled and twisted like a Japanese Chrysanthemum................. 
Asters-Giant Comet-The petals are twisted and curled, resembling the Japanese Chrysanthemum, mixed colors, $1 / 8$ oz., 40 . I0

Giant Comet-White......... Io Crown, or Coc a rde a $u$ - Large white centered flowers....... I0 Dwarf Chrysanthemum - Mixed colors, free bloomer; $1 / 8$ oz., $40 \ldots \ldots \ldots \ldots \ldots \ldots \ldots$. . . .

Dwarf Chrysanthemum-Collection of twelve colors........65 Jewel-Apple Blossom - A new class of aster; flowers $21 / 2$ to 3 in. in diameter, and as round as a ball ................. Io Jewel-Finest Double Mixed-1/8 oz., $50 \ldots \ldots \ldots \ldots \ldots \ldots$........

Lady in White-Resembles the mignon aster in its free branching habits, and in the graceful semi-globular flowers, valuable for bedding or for pots, and for use as a cut flower......... I0 Mignon-Mixed, $1 / 8$ oz., $75 \ldots$ IO "White, $1 / 8$ oz., $75 \ldots$ IO

Triumph - One of the most beautiful dwarf asters ever introduced. Flowers deep scarlet and very large............

Rose Flowered-Large flowers, brilliant and rery double; finest mixed, $1 / 8$ oz., $40 \ldots \ldots \ldots \ldots \ldots \ldots$.

Rose Flowered-White, 1/8 oz., 50...... IO Truaffut's Paeony Flowered Perfection-Th is is the most perfect type of prony-flowered aster in cultivation; the flowers are perfect in quality, form, size and color; finest mixed : colors, $1 / 8$ oz.. $40 \ldots \ldots \ldots \ldots$.... I0

Truaffut's Paeony Flowered Perfection White, pink, purple, scarlet, each, 1/8 oz., $50 \ldots \ldots \ldots \ldots \ldots \ldots \ldots \ldots \ldots$. . . . . . . .

Truaffut's Paeony Flowered Perfection Collection of twelve colors...........60

Victoria-One of the most beautiful asters in cultivation; flowers large, beautifully imbricated, and pyramidal in form, finest mixed, I $/ 8$ oz., $50 \ldots \ldots \ldots \ldots \ldots \ldots \ldots \ldots$ 10

Victoria--White, pink, purple, scarlet, each, 1/8 oz., 6o.

Victoria-Collection of twelve colors....75 " Collection of six colors........45

Needle, or Hedgehog-Petals long and sharply pointed. Finest mixed............... IO Washington-The largest aster grown, bearing flowers 4 to $5 \mathrm{in}$. in diameter and very double; mixed colors, $1 / 8$ oz., $50 \ldots \ldots \ldots$ IO Washington-Collection of six colors.....40 Queen of the Market-The earliest flowering aster. Finest mixed, $1 / 8$ oz., $35 \ldots \ldots \ldots$ o5 Semple's Late Flowering Branching-The flowers are large, resembling the chrysan-

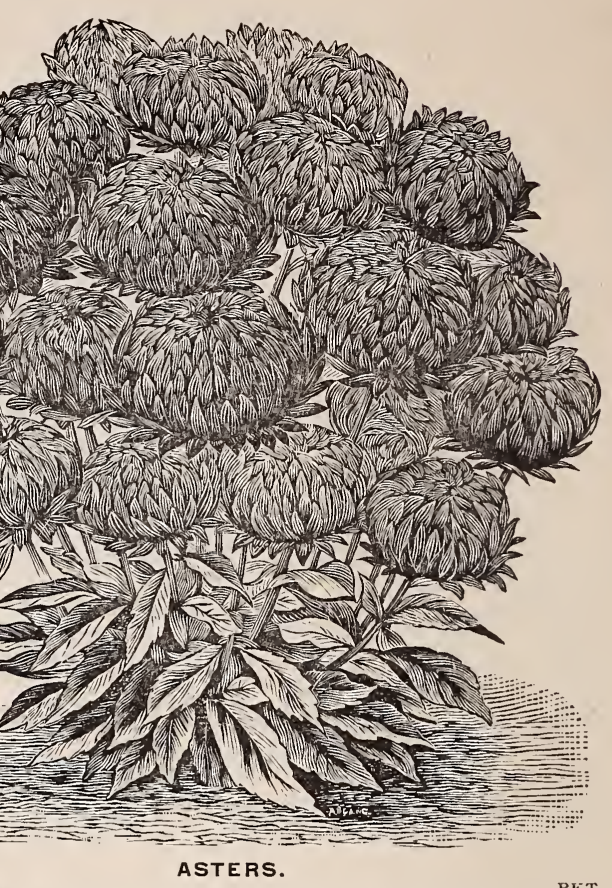

themum, and borne on long stems; desir. able for cutting; strong growing plants, 2 to 3 feet high.

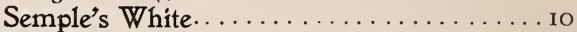

Semple's Lavender.................. Io

Semple's Shell Pink. ................. IO

Semple's Mixed-Above colors, 1/s oz., each,

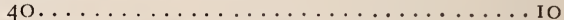

White Princess, or Snowball-An excellent new dwaif white aster, $1 / 8$ oz., $75 \ldots \ldots \ldots$ IO

Bachelor's Button-(See Centaurea Cyanus).

Balloon Vine-A rapid and graceful climber; annual.......................

Balsam-Onè of the finest and most popular summer blooming annuals. They succeed best in a rich soil, and should receive frequent watering of liquid manure.

Camelia-F1owered-Finest mixed; large double flowers.................... 05

Camelia-Flowered Pure White.......... 05

Bartonia-Aurea-Very showy annual, with golden yellow flowers................ 5

Begonia-Tuberous-Beautiful summer and and autumn flowering plants; easily raised from seed.

International Prize-An unsurpassed strain, saved from selected flowers. Finest mixed.30 Double-Splendid mixed............. Vernon-A grand variety; Howers waxey blood-scarlet; foliage very beautiful..... Io 
PKT.

Bellis Perennis-Double daisy. A favorite plant for edging or pot culture. Perennial.

Maxima-The flowers are densely double and as large as a silver dollar; of red and rose tints....................

Longfellow-Double dark rose flowers, I/s oz., $75 \ldots \ldots \ldots \ldots \ldots \ldots \ldots \ldots \ldots \ldots \ldots \ldots \ldots$

Snowball-New pure white double daisy, I/s

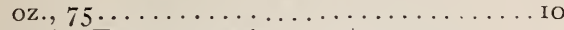

Double Finest Mixed-Uz., \$+.00........ 10

Browallia-One of the finest flowers tor pots. baskets or edging.

Elata-Fine mixed; annual.... ...... 55

Calceolaria - Remarkable for their large, beautifully spotted blossoms.

James's Giant Strain-Choicest mixed.... 50

Calendula-Very showy, free flowering annuals; excellent for beds, borders, etc.

Meteor-Double, light orange striped, oz.,

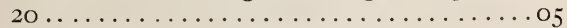

Le Proust-1)ouble, nankeen color, oz., 20. .05

Prince of Orange - Darker orange than

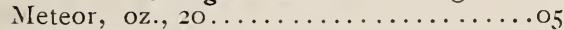

Fine Mixed-oz., 20............... 5

Calliopsis-This genus is amongst the most showy, free flowering, hardy annuals.

Drummondi-Yellow and red....................

Mixed-Finest varieties, oz., $30 \ldots \ldots \ldots$. . . 5

Grandiflora-Large, golden yellow ; $3 \mathrm{ft}$.; hardy perennial...................

Ca mpan u la-(Canterbury Bell). Very showy; excellent for borders, etc. Double

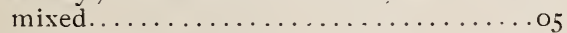

Calycanthema-Mixed............... 5

Candytuft-One of the most popular and useful border plants; very effective in beds, groups, etc.; excellent for cut flowers; annual.

Rocket-IVhite, free flowering, oz., 20...05 Empress-New; pure white: long spikes; oz., $50 \ldots \ldots \ldots \ldots \ldots \ldots \ldots \ldots \ldots$ Io

Mixed-Annual varieties, oz., 20....... 05

Tom Thumb, White-Bushr plants, six inches high; splendid for edging....... IO

Canna-Dark Leaved Varieties-Mixed, oz.,

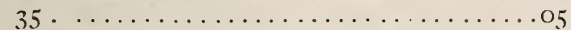

Crozy's Large Flowering Dwarf FrenchMixed colors. A new class of cannas, dwarf in habit, with very large brilliant flowers, oz., $50 \ldots \ldots \ldots \ldots \ldots \ldots \ldots$.

Madame Crozy-Large spikes of deep vermillion: golden bordered flowers......... Io

Carnation-Double Finest Mixed ........ Io

Guillaud-A splendid strain of perpetual carnations, producing 90 per cent. of double flowers, with a large percentage of yellow.......................

Marguerite-A bedutiful new strain of carnations, blooming in four months from the time of sowing the seed, flowers large, double and great variety of colors........ IO Marguerite, White-Pure white, double flowers $\ldots \ldots \ldots \ldots \ldots \ldots \ldots \ldots \ldots$.
Castor Oil Beans-(See Ricinus).

Celosia-(Cockscomb). Very showy, freeflowering plants, producing spikes of feathery flowers. Sow early and transplant out in June; annual.

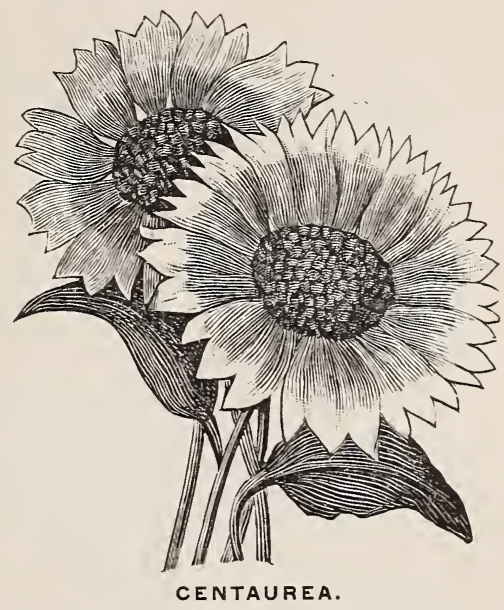

Cristata Nana-Choicest mixture of the newest dwarf varieties................. 5 Ostrich Feather-Crimson, large plumes.. IO Glasgow Prize-A distinct dwarf variety, with dark foliage and crimson combs.... io Plumosa-Thompsoni - Feathered, brilliant crimson.

Centaurea - Candidissima - Silvery - white, deeply cut foliage ............... IO Gymnocarpa-Silvery-gray toliage, drooping habit, oz., $75 \ldots \ldots \ldots \ldots \ldots \ldots \ldots \ldots$. 5 Cyanus Mixed-(Bachelor's Button), tavorite annuals, fine for cutting, oz., 20......05

Cyanus Blue...................... 05 Cyanus-Flore Pleno-New double Bachelor's Button, oz., $25 \ldots \ldots \ldots \ldots \ldots \ldots \ldots$. 5 Marguerite-Pure white, very large flowers: fragrant................... IO Victoria-Dwaif, azure blue, I ft ....... IO Suaveolens-Yellow flowers; sweet scented.05 Moschata-(Sweet Sultan). Finest mixed, sweet scented; fine for cutting, oz., 30...05

Centrosema-Grandiflora-(Buttertly Pra). A hardy perennial vine of rare and exquisite beauty which blooms early in June from seed sown in April; height $S \mathrm{ft}$......... IO

Chrysanthemum-Single Annual Varieties-

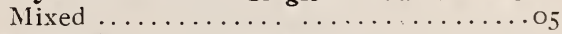

Double Annual Varieties-Mixed......... 05

Segetum Grandiflor am-Sulphur-yellow, Howers $2 \mathrm{x} / 2$ in. across............... 5 Frutescens-(Marguerite). White, with yellow centre................................ Japanese Finest Mixed-Prize strain......25 
Cineraria-Magnificent flowering plants tor greenhouses, etc., in winter and spring.

Giant Prize Strain-Choicest mixet . . . . . .50 Double Large Flowering-. Mixed........ 50 Maritima-(Dusty Miller). Silvery leared. ornamental plants. used for bedding purposes.........................

Clarkia - Mixed - Free flowering: hardy annual .......................

Cobaea Scandens-A beautiful, half-hardy climbing plant of rapid growth. with large. bell-shaped flower:

Alba, White

II)

Coleus - New Hybrids - Mixed. A wellknown ornamental foliage plant........25

Convolvulus - Minor - (Dwarf Morning Glory). Finest mixed, I ft., oz., 10....05 Mauritanicus - Blue; a beautiful trailing plant for.hanging-baskets and vases, perennial.

. 10

Convolvulus - Major - (Morning Glory). Finest mixed, annual, $15 \mathrm{ft} .$. oz., 10.... $0_{5}$

Cosmos-Hybridus-The flowers are from 3 to $t$ in. in diameter. resembling single dahlias; excellent for cutting; easily raised from seed and bloom the flrst season.

Giant Early Flowering Mixed............ Io

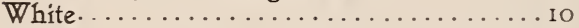

Pink........................ . .

Mammoth Perfection Mixed.............

Golden Yellow "Klondyke"-It begins flowering in June and continues blooming until cut down by frost. The flowers are a rich golden yellow and measure from $2 \mathrm{~T} / 2$ to 3 in. across.

Cuphea-Platycentra-(Cigar Plant). Scarlet, tipped with black and white. I ft...05

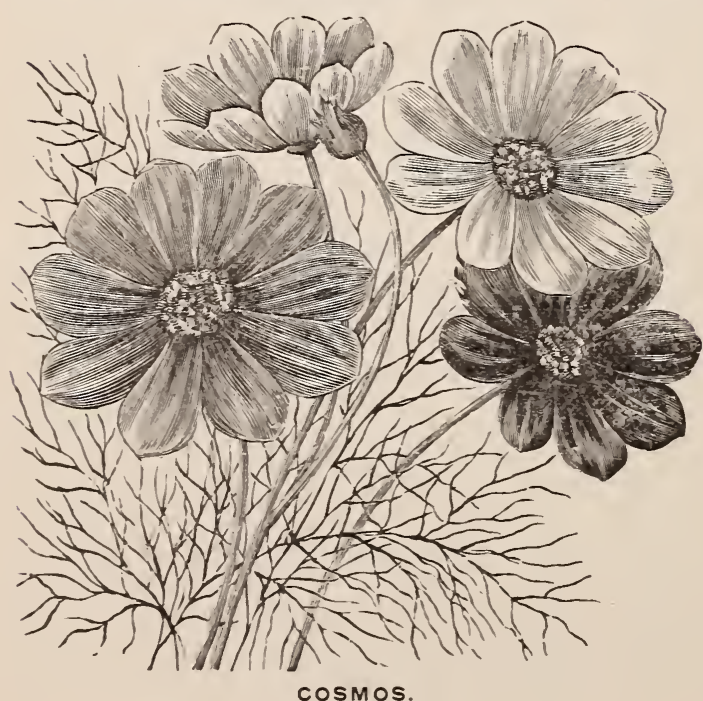

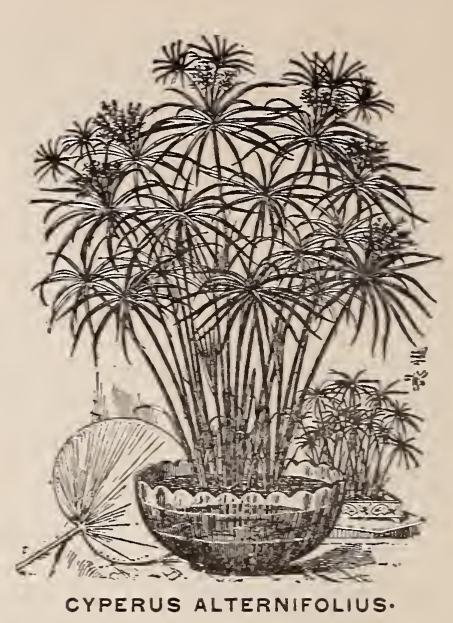

Cyclamen - Percicum Giganteum - Choice strain, mixed..................... 5 Cypress $=$ Vine- - See Ipomara $)$.

Cyperus Alternifolius-('The Umbrella Plant). Handsome foliage plant. excellent for table decoration: easily grown from seed.........................

Dahlia-Double Large Flowering-Seed saved from choice varietics. mixed........... IO Single Mixed-Saved from a superb collec-

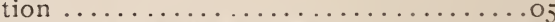

Double Cactus, Finest Mixed-Petals quilled and curved, very beautiful........... Daisy - (See Bellis)

Delphinium - (Larkspur). Very showy. bearing large spikes of towers.

Double Dwarf Rocket-Fine mixed,

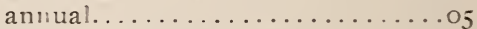
Double Tall Rocket-Mixed.......05 Dwarf Candelabrum-Finest mixed.05 Hybrids, Finest Mixed-Large flowering strain, perennial........... 55

Dat ura-Mixed; handsome bushy plants. trumpet shaped flowers. fragrant. 3 ti.................... 5

Dianthus-A beautiful class of plants, embracing some of the most popular flowers in cultivation.

Chinensis, F1. P1.- China or Indian Pink). Nixed, oz., to.........05 Heddewigi, F1. P1.-(Japan Pink). Large flowering, double choice mixed ..................... 55

Albo Marginata-(Nourning Pink) Deep purple with white edges; double................... $0_{5}$

Diadematus, F1. P1.-(Double Diadem Pink). Splendid variety, with large double flowers; choice colors.....05 Barbatus-(Sweet William). Single mixed : biennial..............05 
Dianthus-Barbatus - Double mixed, large flowering....................

Digitalis-Very showy plant for shrubberies and half shady places; perennial.

Purpurea-Fine mixed..............

Dolichos Lablab-(Hvacinth bean). Mixed; a beautiful, quick growing climber, with blue and white flowers in clusters; an-

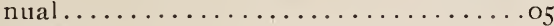

Dracaena-Decorative foliage plants.

Indivisa-Narrow dark green foliage.....20

Latifolia-Broad leaved..............20

Echeveria Metallica-Valuable as a carpet bedding plant.................

Echinocystis-Lobata-(Wild Cucumber). Rapid growing, hardy, annual climber, I 2 feet.......................

Elichrysum-Beautiful everlasting flowers; for winter bouquets; annuals.

Double Mixed Varieties................. 5

Dwarf Double-Finest mixed........... n5

Eschscholtzia-(California Poppy.) Free flowering, handsome annuals, with bright, showy flowers, blooming all through the season till firost.

Mandarin - Rich orange inside; outside brilliant scarlet................. 55

Finest Mixed-All colors.............. 05

Maritima-A new variety, flowers bright golden yellow, each petal marked with a dark orange blotch; silver gray foliage. .05

Ferns-Finest Mixed-Best greenhouse and stove varieties..................25

Hardy Varieties Mixed-Best sorts for out door growing................... 25

Feverfew-(See Matricaria).

Forget $=$ Me $=$ Not $-($ See Myosotis $)$.

Gaillardia-Splendid bedding plants : remarkable for the profusion of brilliant flowers during the summer and autumn.

Lorenziana-Large flowering, double

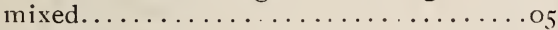

Grandiflora-Finest mixed varieties, peren-

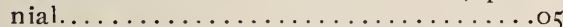

Gnaphalium - Leontapodium - (Edelweiss). The pretty Alpine plant so eagerly sought for hy tourists. Easily raised from seed. . Io

Geum Atrosanguineum-Hardy perennial plants of easy culture, double, scarlet,

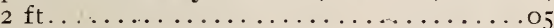

Geranium-Large flowering; choicest varities........................

Gesneria-Closely allied to the Gloxinia. Long-tubed flowers, spotted, foliage beauti-

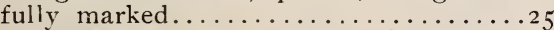

Gladiolus-Lemoines-A beautiful class, with rich, orchid-like flowers............. o5

Gloxinia-Crassifolia-A magnificent strain of erect large flowering varieties in splendid mixture.......................

Godetia - Showy, free-flowering annuals, suitable for beds and borders.

Fine Mixed-From the best varie ties......05
Golden Feather-(See Pyrethrum).

Gomphrena-Handsome, everlasting flower; mixed; all colors................. 5

Gourds-Ornamental-Rapid growing, climbing annual, producing fruit of various torms.

Finest Mixed-Small varieties

White-Nest-egg Gourd.

Gypsophila-A adapted for rock work, edging, etc.

Muralis-Dwarf rose; hardy annual, $3 / 4$ ft . . 55 Paniculata-White; fine for cutting, peren-

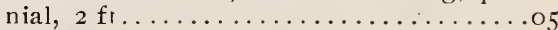

Repens-White, trailing, hardy perennial..o5

Grevillea Robusta - Graceful evergreen foliage plant, tender perennial......... 5

Helianthus - (Sunflower). A well-known genus of hardy annuals, with large and showy flowers.

Californicus, F1. P1.-Orange, extra large and double; 5 ft.; oz., 20.............. Cucumerifolius-Orange yellow flowers; 3 ft., single, oz., $25 \ldots \ldots \ldots \ldots \ldots \ldots$. Cucumerifolius Stella - (Large Flowering Miniature Sunflower.) Flowers are from $21 / 2$ to 3 inches across, borne on long stems. golden yellow flowers : $4 \mathrm{ft}$.; oz., $35 \ldots$. o5 Globosus Fistulosus, F1. P1.-Globe-shaped. vellow ; $6 \mathrm{ft}$; 0z., $25 \ldots \ldots \ldots \ldots \ldots \ldots$.

Nanus-Dwaif double flowers ; $4 \mathrm{ft} . . . . .05$ "Variegatis-Dwarf, handsome variegated foliage $; 4 \mathrm{ft} . \ldots \ldots \ldots \ldots \ldots \ldots . . .65$

Heliotrope - Finest mixed, favorice halfhardy plants for bedding and pot culture, fragrant................... Io

Hibiscus - Africanus - Yellow, with dark maroon centres; annual..............

Humulus-Japonicus-(Japanese Hop). An annual climber, growing with great rapidity ;

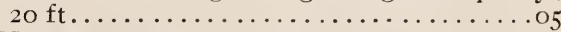

Variegatus-New variety, with handsome variegated foliage.................. 5

Hollyhock-This is one of the finest ornamental plants, with spikes of flowers of almost everv color; they do best in deep, dry soil, enriched with plenty of manure.

Chater's Prize-Choice double mixed...... Io

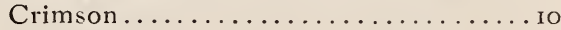

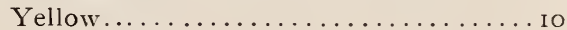

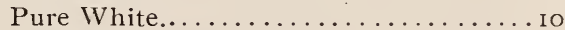

Magenta.....................

Double Finest Mixed-All colors......... 05

Ice Plant-Dwarf growing plants, useful for rock work, baskets, etc., excellent for garnishing; annual.................

Impatiens Sultani-Free blooming plants, with very showy flowers, bright rose, tender perennial; $2 \mathrm{ft} . \ldots \ldots \ldots \ldots \ldots \ldots \ldots \ldots$

Ipomœa-Quamoclit-(Cypress Vine). A well-known climbing vine, with delicate fern-like foliage and star-shaped flowers; annual; i $5 \mathrm{ft} . \ldots \ldots \ldots \ldots \ldots \ldots \ldots$. . . . . 
PKT.

Ipomcea-Grandiflora-(New Hvbrid Moon Flower). Large, pure white, fragrant flower, opening in the evening......... Io

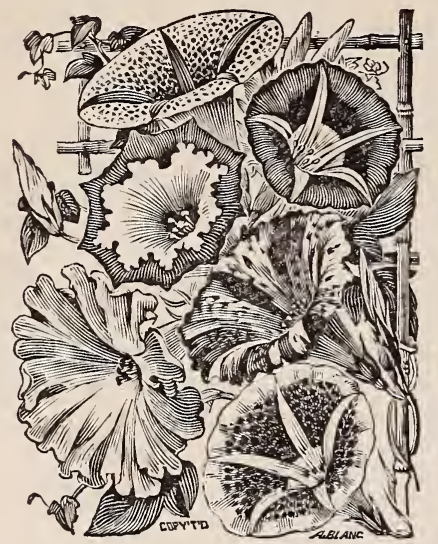

JAPANESE MORNING GLORY.

Imperial Japanese Morning Glory-Very beautiful strain, with immense flowers of finest colors and markings............

Purpurea, F1. P1.-(New Double Morning Glory). Flowers white, with a slight spot of red or blue at the base of the larger petals

Lantana Hybrida-Handsome, free-flowering plants, with beautiful trusses of various hues. Finest mixed.

Lathyrus Latifolius-(Perennial Pea). Free-flowering, hardy, perennial climber. Mixed colors...................... Albus-Pure white.............. Crimson-Fine shade.............. o5

Linaria Cymballaria - (Kenilworth Ivy.) Beautiful trailing plants with small blue flowers, suitable for vases, baskets, etc., tender perennial.................. 5

Linium - (Flowering Flax). Handsome

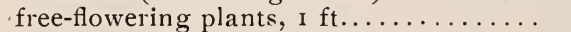
Flavum-Golden yellow, perennial. ..... 05 Grandiflorum Rubrum - Dark scarlet annual ......................... . .

Perennial-Finest mixed............ 55

Lobelia-Dwarf growing plants of easy culture, and admirably adapted for beds, edging, etc.

Gracilis-Blue; best for hanying baskets.. 05 Crystal Palace Compacta-Dark blue; compact growth.................... Io Emperor William-Light blue flowers ; compact variety...................... Golden Queen-Yellow leaved foliage; brilliant blue flowers................. Speciosa-Dark blue, trailing habit...... 55
Lophospernium Scandens $\mathbf{S}$ - Climbir plant for house ple, halfhardy annual; ro ft............... 55 Marigold-(See Tagetes).

Matricaria-(Feverfew). Handsome freeflowering plants; fine for bedding or pot culture; annual.

Capensis-Dwarf; double white; very fine.05

Mimulus-Moschatus-(Musk plant). Sweet scented yellow flower; fine for hanging baskets .................... Tigrinus Grandiflorus-Verv large flowering ; tigered and spotted varieties........... Io

Marvel of Peru-(Four o'clock). Beautiful summer blooming plant; flowers of great variety of colors; oz., I0........... 55

Morning Glory-(See Convolvulus).

Mina Lobata-Half hardy, Mexican climbing

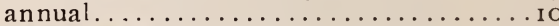

Musa Ensete-(Abyssinian Banana). Magnificent foliage plant for sub-tropical massing........................ I 5

My o s ot is - Palustris - (Forget-me-not). Dark blue, with white eves............ IO Victoria-Beautiful dwaif variety, with large flowers ; finest for pot culture.......... ro

Mimosa Pudica-(Sensitive Plant). The leaves instantly close when touched or shaken. Tenderannual.............. 5

Maurandia-Excellent climbing plant for house or garden; splendid for hanging baskets, window boxes, etc.; mixed colors;

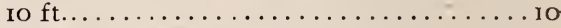

Mignonette - Reseda - A well-known favorite annual.

Grandiflora - Large, flowering, fragrant ;

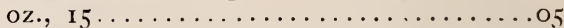
Golden Queen-Golden yellow flowers, dwaif and compact; oz.,60. ............. 55 Giant Pyramidal-Large red flowers; oz.,

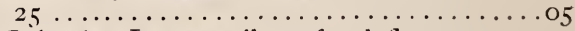
Gabriele-Large spikes of red flowers.... . IO Míles Spiral - Splendid long spikes; oz.,

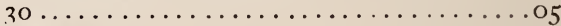
Machet-The best for pot culture; long spikes; oz., 70................ Allen's Defiance-Very large spikes; 12 to 15 inches long; fragrant; the best variety for forcing under glass............... Io

Momordica Balsamina-(Balsain Apple). Beautiful climbing plant, with handsome apple-shaped fruits ; Io ft............ Charantia-(Balsam Pear). $10 \mathrm{ft} \ldots \ldots .5$ Nasturtium-(See Tropieolum).

Nicotiana - Affínis - Sweet scented; pure white; star-shaped flowers, 3 in. across;

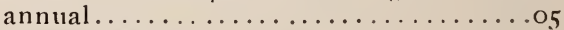
Colossea-Reddish foliage; very handsome; Io $\mathrm{ft} \ldots \ldots \ldots \ldots \ldots \ldots \ldots$. . . . .

Nigella-Damascena-Double mixed. Pretty annuals, known as "Love in a Mist," etc., with large double blue flowers; I $\mathrm{f} 1 \ldots . . .05$ 
Nemophila Insignis-(Annual). Flowers clear bright blue, white centre....05

Finest Mixed.................... Oenothera - Biennis - (Evening Primrose). Half hardy annual; free-flowering plants for shrubbery, etc........ 05

Pansies-Fine Mixture-A good strain of fine colors......................

Finest German Mixed-From a splendid strain of large fluwering and finely blotched varieties................

Large Flowering Prize-Finest mixed. Special mixture prepared by ourselves, which embraces the most siriking and beautiful colors...............20

English Show-From a celebrated English grower; choice strain........25

Bugnot's Superb Blotched-Very beautiful; extra large flowering variety...25 Odier-A distinctly blotched variety of great beautr..................20

Trimardeau, or Giant Pansies-Beantiful class of vigorous growth, and flowers of enormous size: finest strain........ I5

Cassier's - A splendid strain, beautifully marked, large flowers.............20

Giant White - With purple eye; very beautiful......................... 10

Giant Yellow-Black centre............

Peacock-Large peacock blue flowers; white edged....................

Petunia - A profuse-flowering and easily cultivated, favorite annual.

Hybrida-Single, finest mixed; oz., $75 \ldots$. o5

Alba-Pure white, very free bloomer..... 05

Striped and Blotched-Very attractive; oz.,

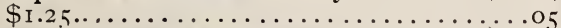

Nana Compacta Multiflora-Very dwarf, with magnificent striped flowers; height 6 to $S$ inches ........................

Fimbriata Flore Pleno-Very large fringed; finest double mixed...............50

Grandiflora, Single-Large flowering; choice mixed.......................20

Fimbriata-Finest mixed; beautifully fringed flowers, in great variety of colors......20

Giants of California-The flowers are very large and of great substance.........25

Phlox-Drummondi-One of the finest annuals for beds, etc.

Grandiflora-Mixed large flowering varieties;

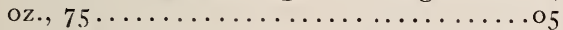

Nana Compacta-Dwarf growing varieties: choice mixed...................

Cuspidata - Finest mixed; beautiful starshaped flowers.....................

Decussata-(Perennial Phlox). One of the best hardy border plants in cultivation; height, 2 ft. Finest varieties mixed..... IO

Poppies - Papaver - Showy, free-flowering plants for beds or borders; succeed well in any good garden soil; annual.

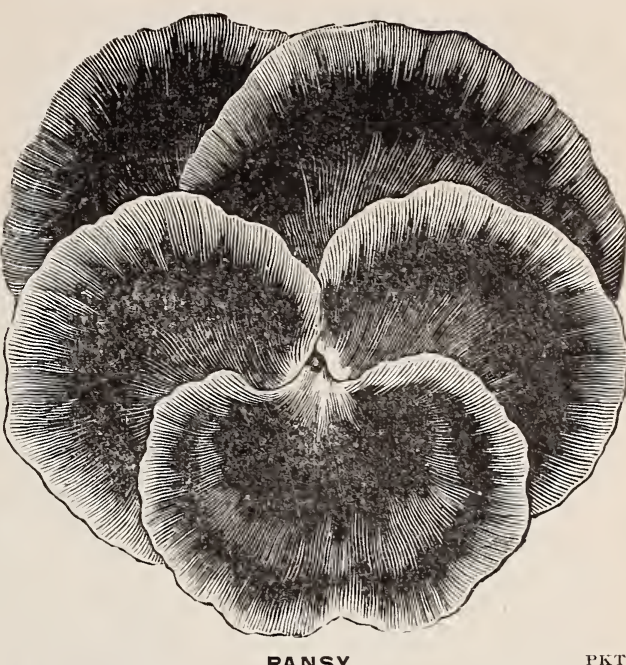

Glaucum-(Tulip Poppy). Vivid scarlet flowers ; single................... 5

Danebrog-(Danish Flag). Brilliant scarlet, with white blotch on each petal......... 55 Umbrosum-Crimson, with black blotch on

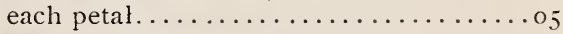

Double Carnation-Mixed; handsome double fringed flowers......................

Double Paeony-Mixed; large peony-shaped

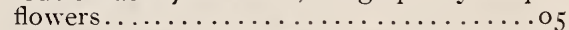

Orientale-(Oriental Poppy). Deep scarlet, with black blotches at the base of each petal. Perennial ..................... 10

Shirley-Single, mixed colors .......... 05

Double Shirley-Semi-double flowers, beauti-

ful.........................

Mikado-Large double Poppy. 'The flowers are white with fringed edges of scarlet ...05

The Bride-Single; white; large ........ 55

White Swan-Pure white: double; very

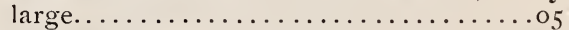

Nudiule-(Iceland Poppy), Single; finest

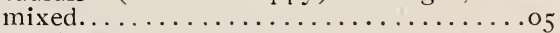

Portulaca-Unrivalled for brilliancy of color, and one of the best annuals for bedding, etc.; grows best in light sandy soil.

Double Extra Mixed-Choicest co'ors..... Io Single Extra Mixed-Choicest colors; oz.

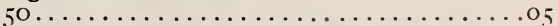

Primula Sinensis-Chinese Primrose - Invaluable for winter and spring decoration in the conservatory or sitting room.

Giant Prize - Large, beautifully fringed flowers of good substance. Plants strong; robust habit......................

Alba Magnifica - Large, fringed; white flowered with yellow eve............50 Chiswick Red - Large, fringed; crimson, scarlet flowers................... 50 
P r i m u 1 a Sinensis - Coerulea - Beautiful

blue........................... 50

Purity-Large flowered; snow-white..... 50 Sinensis Fimbriata Double-Very choice mixture of all colors.................50

Obconica-(Ever-blooming primrose). Flowers of a pale lilac color.............25

Passion Flower-(Passiflora). Rapid growing perennial twiners for greenhouse or sunny positions outside.............

Pyrethrum - Aureum - (Golden Feather). Golden foliage; invaluable for bedding purposes....................... 5

Selaginoides-Fern-leaved foilage....... IO

Rhodanthe - Mixed; beautiful everlasting annual; I foot....................

Ricinus-(Castor Oil Plant). Highly ornamental plants, with large, handsome foliage and colored fruits.

- Gibsonii-Dark red foliage ; 6 feet ; oz., 20. .05 Cambodgensis-The handsomest and most graceful Ricinus, with foliage and stem nearly black; 5 feet: oz., $30 \ldots \ldots \ldots$.... 05 Borboniensis-Large, dark green foliage; 15 feet; oz., 20.................. 55 Sanguineus-Blood red foliage and fruit; 7 feet; oz., 20.................

Fine Mixed Varieties; oz. 20 . . . . . . . o5 Zanzibariensis, Mixed-Gigantic leaves; the most ornamental of all; oz., $30 \ldots \ldots \ldots$. .

Salvia-(Scarlet Sage). Handsome bedding plants, with spikes of brilliant flowers. Tender perennial, blooming the first year from seed.

Splendens-Bright scarlet............ Io Bonfire - Compact growing variety with bright scarlet flowers; $2 \mathrm{ft} \ldots \ldots \ldots \ldots \ldots$.

Patens-Bright blue............... 15

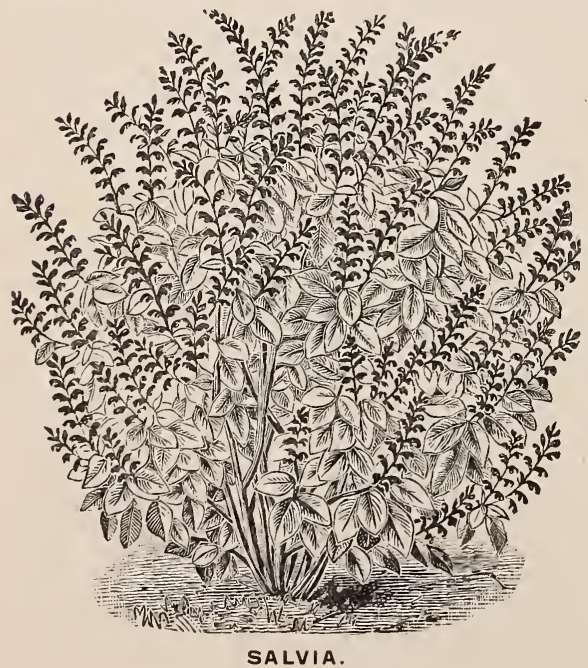

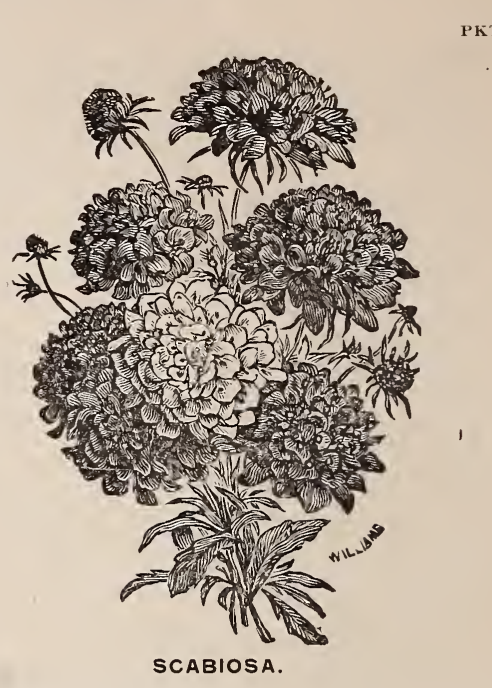

Saintpaulia Ionantha-The plants are very dwarf and spreading, and produce very freely, violet-like flowers, both in shape and color. Excellent for pot culture in the green-house or window............. Io

Salpiglossis - Grandiflora - Finest mixed. One of the most beautiful flowering plants, with very large, richly-colored Petunia-like flowers, elegantly veined and penciled....05

Schizanthus-Finest Mixed-Beautiful and showy, hardy garden annuals; rery free flowering......................

Scabiosa-(Mourning Bride). Handsome summer flowering plants, with beautifully variegated flowers.

Tall Mixed Colors, $2 \mathrm{ft}$. ............. 55

Dwarf Mixed Colors, I ft............ 55

Smilax-A beautiful climber, nothing can excel this plant in beauty of foliage and orange fragrance of flower; tender perennial.......................

Stocks-Much admired for their magnificent spikes of sweet scented flowers, remaining a long time in bloom, excellent for bedding or pot culture; annual.

Large Flowering Ten Weeks-Finest mixed. Io "* " " " Pure white.. 10 Snowflake-A splendid dwarf-growing variety with very large and double pure white flowers................... I5 Cut-and-Come-again-(Princess Alice). Pure white....................... Io Brompton, or Winter Stock-Large flowering, double mixed, half hardy biennial........ Io Giant Perfection-A splendid race, with large spikes of perfectly double flowers, height $21 / 2 \mathrm{ft}$. Finest mixed............. Sweet William-(See Dianthus). 
SWEET PEAS - Fragrant and profuse, flowering hardy annual, in bloom throughout the entire season. The seed should be sown as early as the ground can be worked in the spring, in trenches six inches deep. Prepare the ground by working a large quantity of thoroughly rotted manure. Cover the seed about two inches and as they grow draw the earth around them until the trench is full. Keep the flowers picked off as fast as they come into full bloom, for if the pods are allowed to form the plants will stop blooming. They do best in a sunny situationand plenty of moisture.

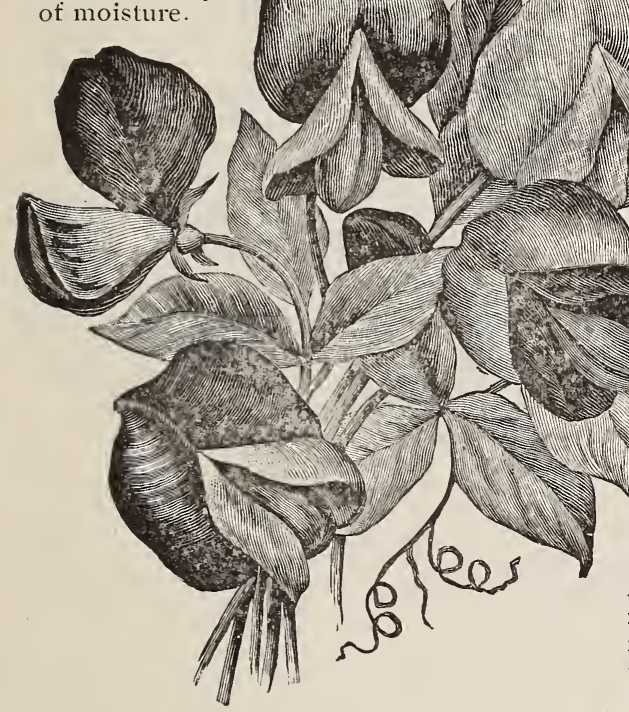

Adonis-Carmine Rose.............. Io

America- $\mathrm{W}$ hite, striped with blood red.... 10

Apple Blossom-Pink and rose.......... Io

Blanche Burpee-Large, pure white........

Blanche Ferry-Pink and white; large.... Io

Blanche Ferry-Extra early; earlier than the

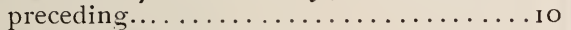

Blushing Beauty -Soft pink...........

Boreatton-Dark maroon..............

Butterfly- White tinted lilac...........

Captain of the Blues-Purple, blue wings... Io

Celestial-Clear lavender..............

Countess of Aberdeen-Blush pink.......... IO

Countess of Radnor-Mauve standards, wings

pale lavender..................

Cupid-White .................... I5

Cupid-Pink ......................

Delight--White, crested with crimson...... Io

Dorothy Tennant-Deep ros!-mauve; large. Io

Emily Henderson-Grand new white pea; flowers as white as snow............. Io

Emily Lynch-Rosy pink standard, shaded

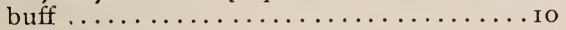

Empress of India-Pink, white wings.......

Fairy Queen--Rose and white........... Io

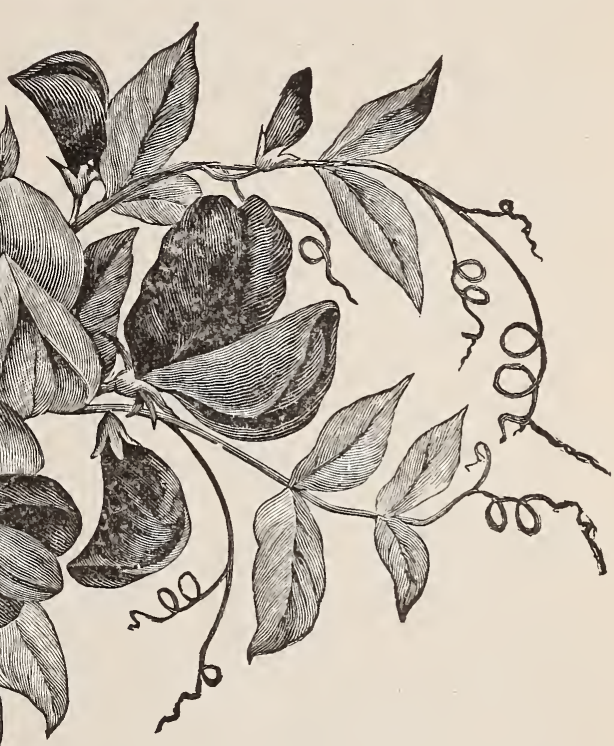

Firefly-Glowing crimson....................

Her Majesty-Bright pink rose........... IO

Indigo King-Standards maroon, wings

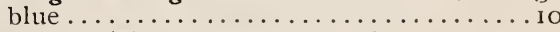

Katherine Tracy-Brilliant pink.......... IO

Lottie Eckford-Lavender and white....... Io

Mrs. Eckford--Primrose yellow........... .

Mrs. Gladstone--Delicate pink........... Io

Mrs. Sankey-Pure white; large flower.... Io

Orange Prince-Orange pink ............ Io

Painted Lady--Pink and white........... . o

Peach Blossom--Pink, shading to buff...... Io

Princess Beatrice--Rosy pink............ IO

Princess of Wales-While, blue striped..... Io

Primrose--Pale primrose yellow...........

Queen ot the Isles-Scarlet striped .......... Io

Red Riding Hood--Rosy red; standards blush pink....................... Romona--Creamy white, flaked with pale pink.....................

Royal Rose-Deep rose, wings rosy pink... Io

Senator - Striped chocolate on creamy

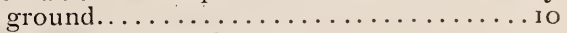

Stanley--Rich, dark maroon............ Io

Venus-Salmon buff.................

Waverly-Standard rosy claret; wings light

blue .....................

Large Flowering Finest Mixed-Our own mixture of the large flowering sorts; none better; oz., 10; 1/4 1b., $25 ; 1 \mathrm{~b} ., 7.5$. 
Sunflower-(See Helianthus).

Tagetes-(Marigold). Well-known freeflowering garden annuals, of rich and beautiful colors.

African - Finest dwarf double varieties: mixed, oz.. 25...................

African Tall-Finest double mixed.oz 25.05

EI Dorado-Large double flowers in finest mixed colors: height $2 \mathrm{ft} ., \mathrm{oz}_{\text {. }}$ 40........ $0_{5}$

Pride of the Garden-Large deep golden flowers. 3 inches across, dwarf, compact habit. I I/2 ft...................

French-Finest dwarf double varieties: mixed, oz.. 25.................

French Striped-Tery fine .............. $0_{5}$

French $\mathrm{T}$ all Mixed....................

Legion of Honor-Large single golden yellow. purple blotched, I ft................... 5

Thunbergia-Rapid growing $\mathrm{clim}$ bers: splendid for trailing over trellises, fences, etc. : height $5 \mathrm{ft}$. : half hard $y$ annuals...05

Torenia-Bailloni-Very pretty, free flowering trailing plants, for hanging basket-, vases, etc. Golden yellow, with brownish red throat

Foumieri-Sky blue with bright yellow throat ......................... IO

Tropaeolum-Canariense-( $\mathrm{C}$ a $n$ a $\mathrm{r} \mathrm{y}$ b i $\mathrm{r}$ vine). Bright vellow: 1o feet.......... Lobbianum-Finest mixed: splendid climbing variety. with dark foliage and handsome flowers, oz., 20

Madam Gunter Hybrids-A new tall rariety : flowers large, rich and various colorings. dark colored foliage, oz.. $25 \ldots \ldots \ldots \ldots$. Io Majus - Tall Nasturtium - Beautiful freeflowering annual climbers, of the easiest culture, unsurpassed for covering trellises. etc. Flowers profusely until killed by frost. Finest Mixed, including named varieties. ${ }^{1}+1 \mathrm{lb} .40,0 z . \mathrm{I}_{5} \ldots \ldots \ldots \ldots \ldots \ldots \mathrm{O}_{5}$ Pearl-Creamy white, oz., i $5 \ldots \ldots \ldots \ldots$. 5 Hemisphericum-Yellow: pink blotches, oz.;

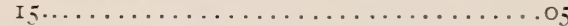
Shillingi-Bright vellow, oz., I $\ldots \ldots \ldots \ldots$.... Regelianum-Purple violet, oz., I5 ......05 Coccineum-Scarlet, oz., I $5 \ldots \ldots \ldots \ldots$.......

King Theodore-Deep maroon, oz., $25 \ldots 05$

Heinemanni-Chocolate color, oz., I $5 \ldots . .05$

Von Moltke-Ruby rose, oz., I 5 ......... 5

Prince Henry-Flowers pale yellow, spotted with brilliant scarlet, oz., $15 \ldots \ldots \ldots \ldots$. 5

Collection of 12 Varieties............. fu

Tom Thumb - Dwarf Nasturtium-Finest

mixed, I/t lb. to, oz.. I $5 \ldots \ldots \ldots \ldots \ldots$. . . . 5 Beauty-Yellow, scarlet striped. oz., 20 . . o5 Scarlet-Oz., 20.................. Spotted-Splendid, oz.: 20........... Empress of India-Crimson. dark leaved variet $y$, oz., $20 \ldots \ldots \ldots \ldots \ldots \ldots \ldots \ldots \ldots$

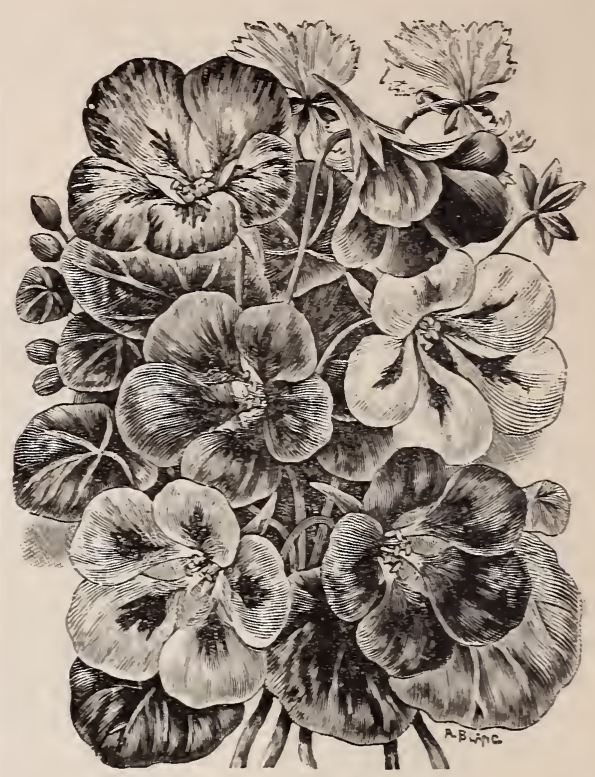

NASTURTIUM.

PKT

Aurora-New chrome yellow; spotted and veined with purplish carmine, oz., 20...05 Cloth of Gold-Golden yellow foliage, flowers brilliant scarlet, oz., $20 \ldots \ldots \ldots \ldots \ldots \ldots$.

Rose-Fine shade, attractive. oz., 20..... 5

Crystal Palace Gem-Sulphur, spotted maroon, oz., 20.................

Golden King-Golden yellow, oz., 20....05 King-Fiery scarlet, with dark foliage, oz.,

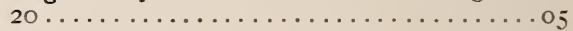

King Theodore-Black red. oz.. 20....... o5 Lady Bird-Orange and purple spotted,

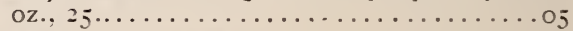

Pearl--Creamy white, oz., 20 ......... o5

Ruby King--Rose, shaded with carmine. oz.. 20......................... 5

Collection of 12 Varieties............. to

Verbena Hybrida-Well-known popular plants. invaluable for summer decoration. blooming the first season from seed.

Choice Mixed-From extra selected named varieties.....................

Candidissima-Pure white...........

Defiance-Brilliant scarlet............

Mammoth Finest Mixed-Large Howers... Io

Vinca-Mixed Varieties-Beautiful free flowering plants: suitable for house culture or bedding purposes; half hardy perennial: $1 / 2 / 2$ feet ................... 
Vinca-Continued.

PKT.

Bright Rose..... ................... o5

Pure White..................... 05

Viola Odorata-(Sweet-scented Violet). A well-known fragrant plant for bedding, etc. ; hardy perennial; $1 / 2 \mathrm{ft} \ldots \ldots \ldots \ldots \ldots$. . . The Czar-Large flower; rich blue...... ro

Virginian Stock - Dwarf, free-flowering, hardy annual. Suitable for bordering and edging; mixed.................... 05

Wallflower-A well-known plant, esteemed for its fragrance.

Finest Double Mixed Varieties

Zinnia - One of the finest free-flowering plants. The flowers are large, beautifully formed, and exceedingly handsome; annual.
Elegans F1. P1.-Finest double dwarf; splendid mixed; oz., $75 \ldots \ldots \ldots \ldots \ldots \ldots$. 05 Double Striped, or Zebra-Beautiful striped flowers ; mixed colors............... 05 Mammoth Flowering, Giant Mixed-A superb strain, with enormous double flowers, in great variety of colors; $3 \mathrm{ft} \ldots \ldots \ldots \ldots .05$ Curled and Crested-Large double flowers, with curled and twisted petals. The colors comprise all the beautiful shades characteristic to the Zinnia................ Io Tom Thumb--Finest Mixed, large flowered; very dwarf $; 3 / 4 \mathrm{ft} \ldots \ldots \ldots \ldots \ldots \ldots . \ldots \ldots$

\section{Ornamental Grasses.}

The ornamental grasses are very graceful and beautiful and are extensively used for winter bouquets and decorations.

Avena Sterilis-(Animated Oats). Hardy annual; three feet.................. 5 Arundo Donax Variegata-Striped foliage. Splendid. Half-hardy perennial; seven feet....................... . 5

Briza Maxima--(Quaking Grass). Annual; three feet....................
Eragrostis Elegans--(Love Grass). Fine for bouquets. Annual; $1 \frac{1}{2}$ feet.......... 05 Gynerium Argenteum--(Pampas Grass). Silvery plumes. Perennial; ten feet....... 05 Coix Lacrymae--(Job's Tears).......... 05 Stipa Pennata - (Feather Grass). Hardy perennial ; $1 \frac{1 / 2}{2}$ feet................. 05

\section{Bedding Plants.}

\begin{tabular}{|c|c|c|c|c|c|}
\hline & 100 & Doz & & 10 & Doz \\
\hline Ageratum, Blue............ $\$ 5$ & 500 & $\$ 75$ & Hollyhock.....Each, $25 \mathrm{c} \ldots \ldots$ & & 250 \\
\hline Alyssum, Double White ....... 6 & 6 oo & 75 & . Each, $25 \mathrm{c} \ldots \ldots$ & & \\
\hline sters, Assorted Colors . & 200 & 30 & Lobelia...... & 400 & \\
\hline sters, Double White . . . . . 2 & 200 & 30 & Marigolds................. & 4 oo & \\
\hline egonias.................. & & I 50 & Nasturtium, Varieties.......... & 400 & \\
\hline dias $\ldots \ldots \ldots \ldots \ldots \ldots$ & & I 50 & Mixed............... & 200 & \\
\hline um Esculentum. & & 250 & Prize, Finest.......... & 350 & \\
\hline $1 \ldots \ldots \ldots \ldots \ldots, 2$ & 200 & 30 & Double.............. & 8 оo & \\
\hline New Dwarf........... & & 250 & Single.............. & 3 oo & \\
\hline $\operatorname{rpa} \ldots \ldots \cdot \cdots 3$ & 3 oo & 50 & Drummondi & 3 oo & \\
\hline$\ldots \ldots \ldots \ldots, \quad y$ & 900 & I 25 & $\ldots \ldots \ldots \ldots$ & & \\
\hline Assorted............. 3 & 350 & 50 & Salvia Splendens, Scarlet ...... & 8 oo & \\
\hline & 400 & 60 & Stocks, Double Assorted ......... & & \\
\hline$\ldots \ldots \ldots+\cdots, \ldots+\cdots$, & & I 25 & Sweet William $\ldots \ldots \ldots \ldots \ldots$ & & \\
\hline eranium, Double............ 8 & 8 oo & I 25 & Verbenas $\ldots \ldots \ldots \ldots \ldots$ & 350 & \\
\hline um, Single........... 8 & 8 oo & I 25 & Vincas.$\ldots \ldots \ldots \ldots \ldots \ldots$ & & \\
\hline eliotrope $\ldots \ldots \ldots \ldots \ldots \ldots$ & 8 oo & I 25 & Zinnias $\ldots \ldots \ldots \ldots \ldots \ldots$ & 200 & \\
\hline
\end{tabular}




\section{SPRAYING CALENDAR.}

The following brief directions for the spraying of fruits and vegetables are the result of several rears experiments made br the Agricultural Colleges.

The calendar may be followed with perfect safety. The number of applications given in each case has particular reference to localities in which fungous and insect enemies are most abundant.

Apple.

Scab, Codling

Moth, Bud Moth.

Cabbage.

Worms, Aphis.

\section{Carnation.}

Rust and other

fungous dis. eases.

Cherry.

Rot, Aphis, Slug.

Currant.

Yildew, Worms.

\section{Grape}

Flea-beetle, fungous diseases.

\section{Nursery Stock} Fungous diseases.

Peach.

Rot and Mildew.

Pear.

Leaf-blight, Scab,

Psvlia and Cod

ling, Moth.

Plum.

Fungous Diseases and Curculio.

Potato.

Beetles, Scab,

Blight.

\section{Raspberry.}

Blackberry.

Anthracnose, Rust.

Rose.

Mildew, Black

Spot, Red Spider, A phis.

\section{Strawberry . Rust.}

\section{Tomato.}

Rot and Blight Worms.

Violet.

Blight, Red Spider.
FIRST APPLICATION. SECOND APPLICATION.

When bud are swell. ing, copper sulphate solution.

After the blossoms have formed, but before and Paris Green.

When worms first If worms or aphides appear, kerosene emul- are present repeat if sion, or Paris Green. plants are not head. aphis.

When planted out, 7 to 12 davs later, dip in Bordeaux. spray plants with Bordeaux.

As buds are breaking, When fruit has set, Bordeaux. When aphis appears, kerosene emul sion.

Bordeaux mixture. If slugs appear, dust leaves with air slacked lime. Hellebore.

At first sign of worms Arsenites.

Io dars later, hellebore. If leaves mildew, Bordeaux mixture.

Before buds burst, When first leaves are copper sulphate solu. half grown, Bordeaux tion and Paris Green. and Paris green.

When buds burst, Repeat at intervals Bordeaux.

Before buds swell,

Before buds swell, Before flowers open, copper sulphate solu- Bordeaux mixture. tion.

Before buds start, Within a week after copper sulphate solu- blossoms fall, Bordeaux tion.

Eariv in spring when buds swell, copper sul phate solution.

When beetles first appear, Arsenites.

Cut out badly diseased canes. Spray with copper sulphate solution before growth starts.

Mildew. Keep heatng pipes painted with equal parts lime and sulphur mixed with sulphur mixed
water to a paste.

Just before blossoms open, Bordeaux and Paris green.

When first fruits hare set, Bordeaux.

When blight is first seen, weak copper sul. phate. Kerosene cmulsion for insects.

When new canes are one foot high, spray with Bordeaux mix. ture.

Black Spot. Spray plants once a week wit weak copper sulphate.

When fruit has set, Bordeaux or weak copper sulphate solution. they open, Bordeaux ing, using emulsion for

THIRD APPLICATION. FOLRTH APPLICATION.

Within a week after Io to If davs later, blossoms have fallen, repeat.

Bordeaux and Paris green.

If aphides persist, or After heads form, use if worms reappear, use saltpetre for worms, a kerosene emulsion, if teaspoonful to a gallon plants are not heading. of water, emulsion for aphides.

Repeat at intervals of While in bloom spray a week or ten days until every week with the blossoms open. dilute copper, sulphate solution.

Io to I4 dars later, if Io to I4 dars later, rot appears, Bordeaux ammoniacal copper car mixture.

If worms persist, hellebore.

As soon as fruit has set, repeat.

I0 to I4 davs later. Bordeaux mixture if disease is present.

of 10 to 14 days

When fruit has set, Bordeaux mixture.

When fruit is nearly grown, am moniacal copper carbonate.

Io to I2 days later, Io to 16 days later, repeat.

Bordeaux.

Io to 14 days later, Io to 20 days later, Bordeaux mixture Con Bordeaux mixture. tinue jarring trees for Keep on jarring trees curculio. for curculio.

5 to 15 days later, Bordeaux

Io to 14 days later, weak copper sulphate solution.

When crop is gath

Red Spider. Kerosene Aphis. Kerosene foliage.

As soon as berries are harvested, Bordeaux (if to be kept longer.)

If necessary. spray with weak copper sul phate solution.

Note.-U'se kerosene emulsion, very weak. 


\section{Summer Flowering Bulbs.}

BEGONIA-Tuberous Rooted-One of the most popular of our summer flowering bulbs, both for planting in the open border and for growing in pots in the green house or sitting room.

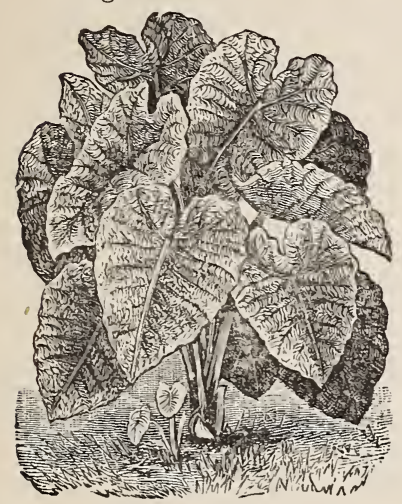

CALADIUM.

Single-Scarlet, Pink, White, Yellow. Each, Io cents; doz. 75 cents.

Double--Finest mixed. Each 20 cents; doz. \$2.00.

CALADIUM-Esculentum-One of the most effective plants in cultivation for the flower border or lawn; it will grow in any good garden soil, and is of the easiest culture. Leares three to four feet long by two feet wide. Height of plant when full size, 6 feet.

Dry Bulbs-Each, IO, I 5,25 cents; doz. \$1.00, \$1.50, \$2.50. CANNAS-Large Flowering Dwarf French.

Alphonse Bouvier-Rich crimson flower, foliage deep green.

Paul Marquand-Flowers salmon red, foliage dark green, very large.

Austria-Canary yellow, spotted with brownish red.

Italia-Bright red, bordered with golden yellow, foliage large and heavy.

Madame Crozy--One of the very best. Bright scarlet flowers, distinct bright yellow border.

Florence Vaughan-The most striking of the yellow spotted varieties, foliage light green.

Charles Henderson-Color bright crimson, centre of the flower marked with golden pencilings, handsome.

Egandale-Bronze foliage, large, bright. cherry-red flowers.

Queen Charlotte-Resembles Nadame Crozy, only that it has a much wider band of yellow around each petal.

J. D. Cabos--Rich maroon foliage. Flowers peculiar rich shade of orange.

Paul Bruant-Large orange scarlet flower, toliage dark green.

Emile Leclere--Golden yellow, foliage green.

Alsace-Fine new white Canna.

Geoffrey St. Hillaire-Large flowers of deep orange red, bronze foliage.

General Boulanger--Large bright canary yellow flowers, foliage green.

The price of any of the above dormant roots, Io cents each, \$r.oo per doz.

Tall Canna Robusta-Height $S$ feet, large leaves, $4 \mathrm{ft}$. long by $\mathrm{I} / 2 \mathrm{ft}$. wide, $75 \mathrm{c} \mathrm{doz}$.

DAHLIAS-Choice assortment. Each 15 cents; doz. \$I.50, except where noted.

William Agnew--The grandest red Cactus Dahlia ever produced. The flowers are large, sometines measuring more than seven inches in diameter, always full to the centre; of perfect form, while the color is the richest shade of intense red. Each, 30 cents.

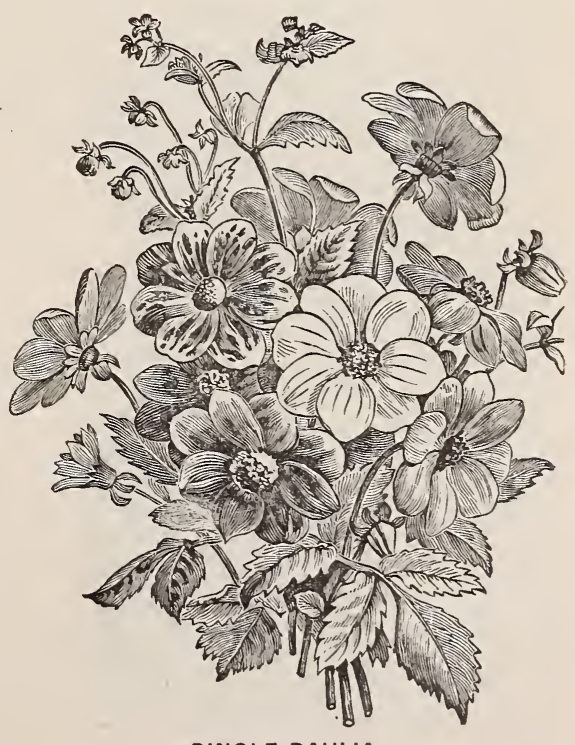

SINGLE DAHLIA. 


\section{DAHLIAS-Continued.}

Snowclad-The finest white pompom to date, a strong, vigorous grower, of branching habit and such a profuse bloomer as to suggest the name. Each 30 cents.

A. D. Livoni--Best clear, soft pink show dahlia. Blooms from June until frost.

American Flag--Snow white, heavily bordered cherry, sometimes a central stripe of same color.

Beauty-Snow white, of perfect form and good texture. One of the best whites.

Crimson Ball-Bright crimson purple, of perfect ball shape, and constant bloomer.

Duchess of Cambridge-The best all round fancy dahlia. White suffused pink edged purple.

Dandy-Ground color pure pink, striped and penciled black. This is a general favorite.

Fern=Leaved Beauty-Fern like foliage and dwarf branching habit. Creamy white margined crimson.

Frank Smith-An old favorite, dark purplish maroon, tipped pinkish white.

John Sladden-Perfect globular form, large dark maroon, almost black. Best dark show dahlia.

Nero-Deep crimson maroon, large and full, long stems, and excellent for cutting.

Ruby Queen-Color of American Beauty Rose, early and profuse bloomer. The best for all purposes.

Catherine-The best pure yellow, of fine form, full to the centre and on long stems.

Crimson Beauty-Rich, glistening crimson, of good shape; the best of its color.

Juliette-A beautiful variety, yellow, shaded and tipped orange crimson.

Black Prince-Flowers large, of perfect form and full to the centre; intense velvety maroon, almost black. Profuse bloomer.

Henry Patrick-The best pure white, flowers large, on long stems, early and profuse.

Mrs. Geo. Reed-White edged and llaked soft rosy lake.

Mrs. Peart-Flowers are creamy white, shaded soft yellow at base of petals.

Ny mphæa-Flowers medium to large, always full to the centre, and clearly resembles the pink Water Lily. A mass of bloom from June till frost.

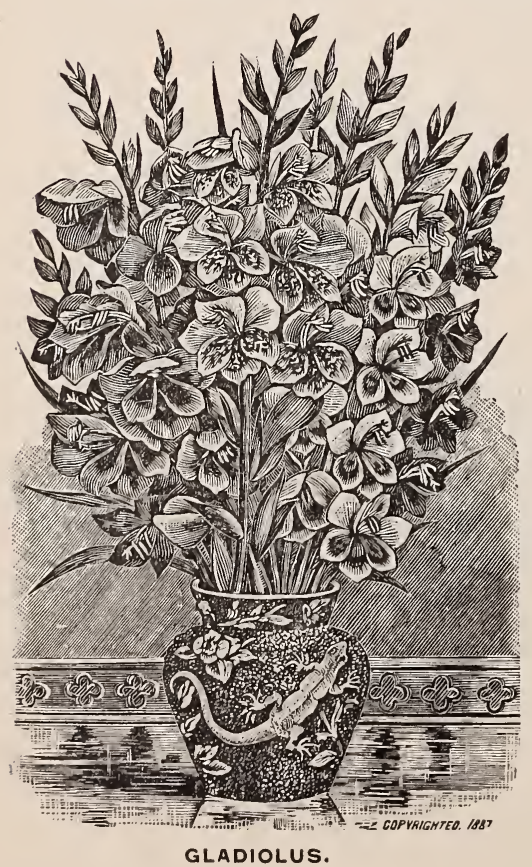

Oban-Beautiful and distinct in form and color being a rosy lavender, overlaid delicate silvery fawn, strong grower and continuous bloomer.

Dozen Per 100

GLADIOLUS -- Superior quality, fine mixed.............

Mixed Hybrids-All colors.

$\begin{array}{rrrr}25 & & \$ 1 & 75 \\ 35 & & 2 & 00 \\ & & & \\ 1 & & & \\ 50 & & 3 & 00 \\ & & & \\ 40 & & 2 & 50 \\ 30 & & 2 & 00 \\ 40 & & 3 & 00 \\ 20 & & \text { I } & 25\end{array}$

Lemoines Hybrid - Mixed varieties. Bright coloring and odd markings.......

Snow White-The best white Gladiolus. The entire flower is a perfect paper white with a slight cream shade on lower half of the petal; the spikes are large and set thickly with flowers. Each 20 cents; doz., \$2.00. 


\section{GLADIOLUS-Continued.}

Brenchleyensis - Bright vermillion scarlet, fine for planting in masses amongst shrubbery, etc. Doz. 25 cents; $\$ \mathrm{I} .50$ per 100.

Isaac Buchanan--Pure Yellow, best for massing. Doz. 65 cents; $\$ 4.00$ per 100.

Shakespeare - White, slightly suffused with carmine rose; large rosy blotch. 1)oz. 90 cents; $\$ 5.00$ per Ioo.

John Bull--White, slightly tinged with sulphur. Doz. 65 cents; $\$ 4.00$ per 100 .

Octoroon--Salmon pink, very beautiful. Doz. \$1.00: \$5.0o per 100 .

Ceres--Pure white, spotted with purplish rose. Doz. 50 cents; $\$ 2.50$ per 100 .

Emma Thursby - White ground, carmine stripes through petals, blotch on the lower division. Doz. 65 cents; $\$ 4.00$ per 100 .

Eugene Scribe--Tender rose shaded with carmine red, flowers large. Doz. 65 cents; $\$ 4.00$ per Ioo.

General Sherman--Large fine scarlet. Doz. 65 cents; $\$ 4.00$ per 100 .

Martha Washington--Light yellow, of large size, lower petals tinged with rose. Doz. 60 cents; \$4.oo per Ioo.

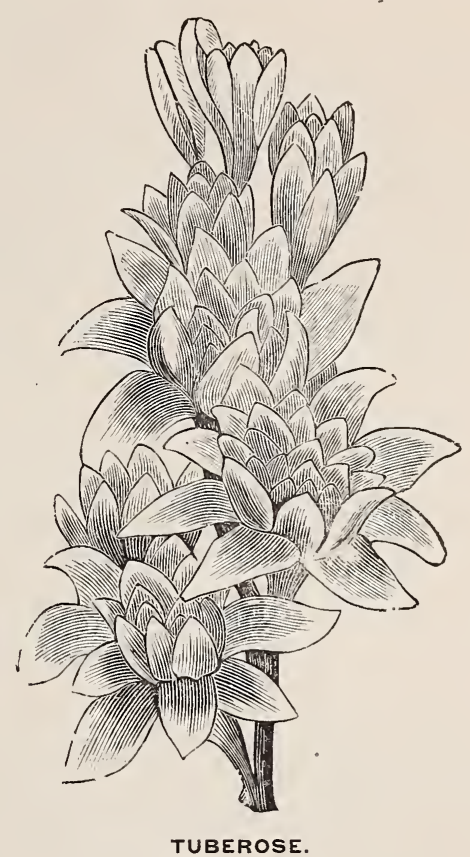

Madame Monneret-Delicate rose. Doz. 50 cents; \$2.50 per Ioo.

May-White ground, slightly striped crimson, extra. Doz. 65 cents; $\$ 4.00$ per 100 .

GLOXINIA-Excellent for greenhouse or window culture. Each Io cents; doz. \$I.oo.

HYACINTHUS Candicans--Summer flowering white giant Hyacinth. Each 5 cents; doz. 50 cents.

LILIUM Auratum-(Golden Banded Lily). Flowers white, studded with crimson spots, having a golden band through the center of each petal. Each ${ }_{5}$ cents; doz. \$1.50.

Lancifolium-(Speciosum)-Album-Pure white, fragrant; very hardy. Each 25 cents; doz. $\$ 2.5$ o.

Roseum-White, shaded and spotted with rose. Each I5 cents; doz. \$1.50.

Rubrum-White, shaded with rose and spotted red. Each 15 cents; doz. \$1.50.

Tigrinium-(Tiger Lily). Orange red, spotted black. Each Io cents; doz. \$I.oo.

Tigrinium flore pleno-(Double Tiger Lily). Each I5 cents; doz. \$1.50.

MADEIRA VINE-A half hardy, tuberous rooted climbing plant, fragrant white flowers. Each 5 cents; doz. 5o cents.

TIGRIDIA-Very handsome summer flowering blubs.

Conchiflora-Orange spotted with crimson. Doz. 50 cents

Grandiflora Alba-Pearly white flowers, spotted with crimson. Doz. 50 cents.

TUBEROSE-Dwarf Double Pearl-Large flowering bulbs. Doz. 25 cents; \$I.50 per Ioo.

\section{AUTUMN, 1899. DUTCH FLOWERING BULBS.}

Our annual illustrated catalogue of bulbs for fall planting will be issued in September and mailed to our customers, and to all others on application.

We handle strictly first quality Hyancinths, Tulips, Crocus, Daffodils, Lilies, Snowdrops, etc. Our prices will be as low as quality will permit. 


\section{CLIMBING PLANTS.}

AMPELOPSIS - Veitchi-(Japanese Iry). A beautiful hardy climber. Each, 25 cents; doz. \$2.50.

Quinquefolia-(Virginia Creeper). Each 50 cents.

ARISTOLOCHIA - Sipho - (Dutchman's Pipe). Very large, foliage ten inches in diameter, and curious pipe-shaped yellowish brown flowers. Each \$I.oo.

CLEMATIS - Jackmanni - Rich velvety purple. The best variety for general cultivation. Each \$1.00.

Henryi-Large, showy; pure white. Each 75 cents.

The Gem-Deep lavender blue, blooming frequently during the season. Each $75 \mathrm{c}$.

Coccine a - A very handsome hardy climber, with brilliant scarlet flowers. Each $\$ 1.00$.
Flammula-Large clusters of small white flowers, fragrant. Each \$1.00.

Paniculata-Very rapid climber, hardy, bears a profusion of large pinnacles of snow-white star-shaped fragrant flowers late in summer. Each \$r.oo.

WISTARIA - Chinensis - (Chinese IVistaria). A rapid-growing climbing-plant producing long racemes of pale blue Howers.

Tecoma Grandiflora -- Large trumpetshaped flowers, brilliant orange, adapted for covering walls or arbors, hardy and rapid grower. Fach 50 cents.

HONEYSUCKLE - Belgians, or Dutch Monthly - Flowers fragrant, red and yellow. Each 35 cents.

Hall's New Japan - Vigorous grower, Hower's pure white, fragrant. Each 5o cents.

\section{HARDY PERPETUAL ROSES.}

\section{Extra Strong Plants. 50 cents Each. $\$ 5.00$ per Dozen.}

Baronne de Bonstetten-Deep red, large, strong grower.

Baroness Rothchild-Robust grower; clear pale rose, tinted with white, very large and double.

Coquette des Alps-Free grower and abundant bloomer, white shaded rose, medium size, good form.

La France-Satiny rose, large, full.

Paul Neyron-Dark rose, very large.

Ulrich Brunner-Cherry red, large and fine.

White Baroness-Pure white.

Duchess of Albany-Rich deep pink.

Mabel Morrison-Very fine white; pale pink in autumn.

Marshall P. Wilder-Cherry carmine.
General Jacqueminot-Brilliant scarlet. Duchess of Edinburgh-Deep crimson. Madame Gabriel Luizet-Delicate pink.

John Hopper-Bright rose. carmine centre. Queen of Queens-Pink, blush edges.

Fisher Holmes-Large, deep, velvety crimson flowers, double and of excellent form.

General $\mathbf{W}$ a shington-Crimson, freeflowering.

Magna Charta-Bright pink, with carmine.

Countess of Oxford-Bright carmine, large and full.

Mrs. John Laing-Large, soft pink.

Anna de Diesbach-Carmine rose. rery large and fragrant.

\section{MOSS ROSES.}

75 cents Each.

Blanche Moreau-Pure white, large, well mossed.

Countess de Murinais-White, large and double.

Crested-Bright rose, large buds.

Gloire des Mousseuses-Pale rose.

Princess Adelaide-Pale rose color. large.

Luxembourg-Deep crimson, large.

\section{CLIMBING ROSES. \\ 50 cents Each.}

Baltimore Belle-Blush white.

Gem of the Prairies-Crimson, fragrant.

Queen of the Prairies-Bright red, large.

Crimson Rambler-A rapid grower, attaining a height of 10 feet in a season. The
Howers are produced in trusses, pyramidal in shape, and of the brightest crimson color, perfectly hardy.

Climbing Victor Verdier-Rosy carmine. Yellow Rambler-Clear yellow.

Can Supply Other Varieties not Specified in this List. 


\section{Small Fruits and Fruit Trees.}

\section{APPLES.}

Trees five to seven feet, 50 cents each. Larger size, from $\$ 1.00$ to $\$ 2.00$.

Astrachan Red-Large, crimson.

Early Harvest-Medium size, straw color. Northern Spy-Large, one of the best.

Rhode Island Greening-Greenish-yellow, prolific.

Baldwin-Large, bright red.
Bellefleur-Yellow, with blush cheek.

Porter-Light yellow.

Wealthy-New. White, shaded with crimson.

Maiden's Blush-Pale yellow and red.

Talman's Sweet-Medium size, pale yellow.

\section{PEARS.}

Four to five feet, 50 cents. Six to eight feet, $\$ 1.00$.

Bartlett-Splendid variety.

Belle Lucrative-Medium size, green.

Seekel-Small, one of the best.

Sheldon-Large, delicious flavor.

Buffum-Medium size, yellow, shaded with red.
-Winter Nelis-Medium size, one of the best winter.

Clapp's Favorite - Large, yellow, with brown dots.

Beurre Hardy - Large, greenish-russet, pleasant flavor.

\section{CHERRIES.}

Four to five feet, 75 cents each. Five to seven feet, $\$ 1.00$ each.

Black Hart-Deep black.

Black Tartarian-Large, purplish-black.

Coe's Transparent-Amber, very sweet.
Napoleon-Large, white, with red cheek.

Olivet-New. Large, deep red.

May Duke-Dark red.

\section{BLACKBERRIES. \\ Per dozen, $\$ 1.00$.}

Agawam-Early, fine flavor.

Early Harvest - Very early, enormous bearer.

Erie-Very large and early.

Kittatinny-Large, very sweet, hardy.
Wilson's Early-Very productive.

Snyder-Hardy, medium size.

Taylor's Prolific-New variety, large.

Wachusett Thornless-Fair size, excellent quality.

\section{RASPBERRIES.}

Per dozen, $\$ 1.00$, except when noted.

Cuthbert-Large, rich, crimson, best quality. 4 Gregg-Large black variety. Doz. \$r.5o.

Golden Queen-Color amber, very pro- Herstine-Large, deep crimson.

ductive. Doz. \$2.0o.

Souhegan-Jet black, medium size.

\section{CURRANTS.}

Per dozen, $\$ 1.00$, except when noted.

Black Naples - Handsome, black; large Fay's Prolific-New red rariety. \$2.00. berries.

White Grape-Finest white currant.

Red Dutch-Popular old variety.

Cherry-Large size, deep red.

HARDY GRAPES.

Three year old vines, 50 cents each.

Agawam-Large, dark red.

Brighton-Red, long bunches.

Catawba-IVell-known variety.

Concord-Very productive.
Delaware-Very fine flavor.

Niagara-Large and productive.

Moore's Early-Large, sweet.

Worden-Similar to the Concord. 


\section{FERTILIZERS.}

\section{Prices Subject to Change.}

Pulverized Sheep Manure-The richest natural manure, and the most nutritious food for plants. Its effect is immediate, much more lasting and healthy than guano or any other manure. It is the best manure for mixing with the soil for greenhouse plants. It makes the richest, safest and quickest liquid manure, rivaling guano without any deleterious effects.

Directions-For mixing with soil, use I part manure to 6 parts soil. For making a liquid, use I pound manure to 5 gallons of water.

Price per original bags (about 100 lbs..) $\$ 2.50$; 10 lbs., 50 cts.; 5 lbs., 30 cts.; 2 lbs., 15 cts.

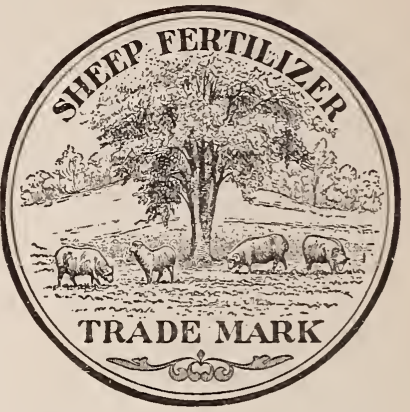

Canada Unleached Hardwood Ashes-As a fertilizer for lawns and gardens hardwood ashes are unequalled; they supply natural plant food, permanently enriching the soil. One of the best for lawns, giving the grass a rich, dark shade of green, and destroying many of the insects which are so injurious to grass, roots and leaves. Price per 100 lbs.; $\$ 1.00$; ton, \$18.00.

Bowker's Hill and Drill Phosphate-A concentrated general fertilizer used either alone or with manure. This phosphate is made, as its name implies, for the hill or drill, or for broadcast sowing. IT IS COMPOSED PRINCIPALLY OF BONE, thoroughly dissolred so as to make it active in all stages of plant growth. Per bag Ioo lbs.; $\$ 1.75 ; 50 \mathrm{lb}$. bag, $\$ 1.00$.

Stockbridge Special Manures-They were the first special manures introduced in this country, and are founded on the principle of supplving the crop, in suitable proportion, with that plant food which it requires. The following are the leading brands: Potato, Corn and Grain, Grass Top Dressing, Small Fruits, Vegetables, Root Crops and Celery. Price, 100 lb. bag, $\$ 2.00$; ton, $\$ 38.00$.

Bowker's Greenhouse Dressing-A special fertilizer for use under glass. It can be used alone directly on the beds or pots or in solution; produces a healthy vigorous growth and greatly improves the color of the foliage and blossoms. Price, $25 \mathrm{lb}$. bag, $\$ 1.00$.

Bradley's Superphosphate-A well-known brand of fertilizer for general use on all farm and garden crops. Price, $100 \mathrm{lbs}$., $\$ \mathrm{r} .75$.

Dissolved Bone Black-Contains ${ }_{5} 5$ to $\mathrm{I} S$ per cent. soluble and available phosphoric acid. $100 \mathrm{lbs} ., \$ 1.5 \mathrm{O}$.

Pure Ground Bone-This is a very pure, finely pulverized form of ground bone, especially prepared for rose culture, top dressing for lawns and for potted plants. Price, $5 \mathrm{lb}$. package, $20 \mathrm{cls}$. ; ro lb. package, $35 \mathrm{cts}$; per 100 lbs., \$1.75; per bbl., \$I.50 per roo lbs.

Bowker's Lawn and Garden Dressing-Prepared for Lawns, Gardens and Flower Beds. Thi dressing is prepared from chemicals, free from weed seeds, nearly odorless, clean

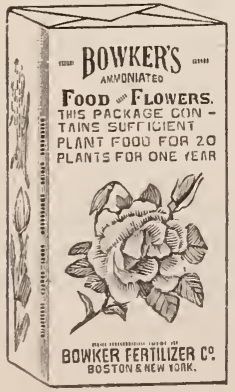
to handle and easily applied. It acts gradually through the season, and produces a luxuriant growth of grass of a rich green color. It is also a superior dressing for the flower garden.

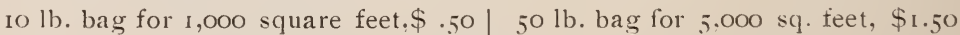

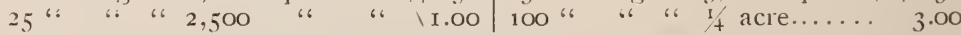

Bowker's Ammoniated Food for Flowers-Soluble in water. A fertilizer made from chemicals and prepared especially for plants grown in the house, garden or conservatory, clean, odorless, and producing early and abundant blossoms of rich and brilliant color, and healthy luxuriant plants.

Directions for use with each package.

Small package, $15 \mathrm{cts}$; large package, $25 \mathrm{cts}$. 
Nitrate of Soda-High grade, 95 to $9 \$$ per cent. pure, being extremely soluble, it should be applied when the plants are above ground, mixed with wood ashes or land plaster. Price, 5 lbs., $30 \mathrm{cts}$; 10 lbs., 50 cts.; 25 lbs., \$1.00; 100 lbs., \$3.00.

Sulphate of Ammonia-2+ to 25 per cent. ammonia. Price, $100 \mathrm{lbs}, \$ 4.00$; 10 lbs, $60 \mathrm{c}$.

Muriate of Potash-So to $S_{5}$ per cent. Price, Ioo lbs., $\$ 3.00$; Io lbs., 50 cts.

Flour of Gypsum-An excellent addition to land for such crops as require lime and sulphate: also for mixing with Paris Green and other insecticides, for the extermination of potato bugs and other insects. Price, bag of $200 \mathrm{lbs}$., \$r.oo.

Tropikfibre is a product of the tropics, of a light, fibrous, spongy character that possesses great power of absorption. It is entirely free from weed seeds and all disease germs, such as rust, blight and scale, it haring been thoroughly sterilized by treatment under steam. If used in connection with earth, it lightens it up wonderfully; and as it can be fertilized to any degree, it will aid in producing that rapid, luxuriant growth which is sought by so many Hower growers. Pkg., $15 \mathrm{c} ., 25 \mathrm{c} ., 5 \mathrm{oc}$.

Jadoo Fibre and Jadoo Liquid-A new growing material for all kinds of plants. It is of a light, spongy nature and retains moisture. In potting always use pots two sizes smaller than when earth is used. Price, $5 \mathrm{lbs}$, 30c.: 10 lbs., 50c.: $25 \mathrm{lbs}$. \$r.10; in bags of about I $20 \mathrm{lbs}$., at $3 \mathrm{c}$. per lb.

Jadoo Liquid-A concentrated liquid fertilizer. Can be used for plants grown in Jadoo Fibre or soil. Price. per pint, 25 cents. Special circular sent on application.

\section{INSECTICIDES.}

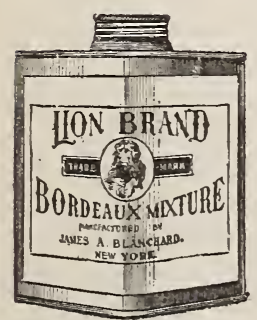

Ant Exterminator. For the destruction of ants in lawn and pleasure grounds. Directions for use on each package. Put up in three sizes, $25 \mathrm{c}$., 50c.: \$1.00.

Bordeaux Mixture. A valuable and indispensable fungicide for grape growers. It prevents potato blight, mildew, black rot, etc. To every one qallon of mixture add 49 gallons of water. Price, I gallon can, \$I.OO; I quart can, 4 oc.

Death to Lice. (Lambert's.) A cheap and

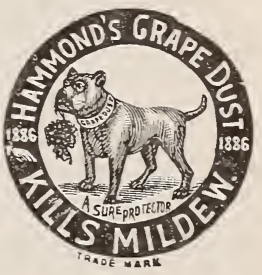

effective remedy for all kinds of poultry vermin, lice on cattle, horses or plants. Directions on each package. Each, $25 \mathrm{c}$., 5 oc., \$r.oo.

Dalmation Insect Powder. Small tins with perforated top, Ioc.; 1/2 lbs., $25 \mathrm{c}$.; I 1b., $45 \mathrm{c}$.

Fir Tree Oil. Soluble. For destroying all insects and parasites that infest plants, without injuring the plants. It is also an excellent wash for dogs and other animals, and is harmless to the hands and skin. Directions with each package; $1 / 2$ pint, $40 \mathrm{c}$.; pint, $65 \mathrm{c}$.; quart, \$1.15; gallon. \$4.00.

Fir Tree Oil Soap. An effective insecticide for the destruction of mealy-bug, aphis, caterpillar, etc. It does not injure fruit or foliage. One ounce makes a gallon of liquid. Price, 1/2 lb. tins, $25 \mathrm{c}$.; 2 lb., $75 \mathrm{c}$.

Flour of Sulphur. A preventive and cure for mildew on grape rines, rose bushes, etc. Apply with powder gun or bellows. Per lb., 6c.; 5 lb. package, 25c.; 10 lb. package, 5 oc.

Fostite. To prevent and check mildew and black rot on fruits, plants and regetables, it should be used on the plants while the foliage is moist. It is a powder and easily applied with a powder bellows or a powder gun; 2 lb. package. $25 \mathrm{c}$; $5 \mathrm{lb}$. package. 5 oc.

Fungaroid. A powdered Bordeaux Mixture. Prevents mildew on grapes and other fruits, regetables, and all diseases of a fungus nature. I lb., $15 \mathrm{c}$; $5 \mathrm{lbs} ., 75 \mathrm{c}$.

Gishurst Compound. An English preparation for destroving scale, mealy-bug. thrip. etc. Per lb. box, 6oc. 


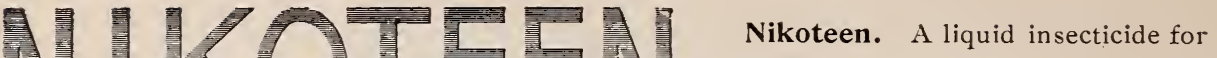 A LIOUID INSECTICIDE spraying or vaporizing. Specially A LIQUID INSECTICIDE 1 prepared for use in greenhouses.}

Grape Dust, Hammond's. For the prevention of mildew on roses, grapes, etc. It is not only a preventive, but it cures plants already affected. Apply with bellows. I'rice, $5 \mathrm{lb}$. package, $3.5 \mathrm{c}$.

Hellebore. (Strictly Pure). One of the best insecticides for the destruction of rose slugs, currant worms, etc. Dust on with powder gun or bellows. Price, $1 / 4 \mathrm{lb}$. package, 10c.; $1 / 2$ lb. package, $15 \mathrm{c}$.: per pound, $25 \mathrm{c}$.

Little's Antipest. Price, quart cans, \$r.00; 1/2 gallon cans, \$r.50.

London Purple. Per lb. box, 20c.

Paris Green. This poison is more universally used for the destruction of potato bugs than any other. Per lb., $25 \mathrm{c}$.

Morrill's Canker Worm Exterminator. One of the best and cheapest remedies for the protection of trees from the ravages of the grub and canker worm. Directions with each can; 2 lb. cans, 30c.; 5 lb. cans, 6oc.; Io lb. cans, $\$ 1.10 ; 20$ lb. cans, $\$ 2.00$.

Slug Shot. (Hammond's). A non-poisonous powder and a rery popular insecticide, destroys insects injurious to house and garden plants; $5 \mathrm{lb}$. package, $25 \mathrm{c}$. ; IO lb. package, 5 Oc.

Sulpho=Tobacco Soap. For destroying rose slugs, green fly, lice and eggs of insects. Price, in tin box, with directions, sufficient for five gallons of water, $25 \mathrm{c}$.

Tobacco Dust. Kills black and green fly, etc. Spread upon the ground it keeps off all earth insects, and also acts as a fertilizer. Apply with powder duster or bellows. Per lb., IOc.; 5 lb. package, $25 \mathrm{c}$.; per 100 lbs., $\$ 3.00$.

Tobacco Extract. A strong nicotine solution. Destroys green fly, mealy bug, scale, etc. Apply extract by vaporizing. Gallon can, \$r.oo.

Tobacco Stems. For fumigating greenhouse, for the destruction of green fly and other insects. Dampen before lighting. Per bale, IOO lbs., \$1.50; $200 \mathrm{lbs}$., \$2.50.

Whale Oil Soap. Effective in destroying insects and lice on plants, trees, etc.; I lb. box, 15 c. ; 2 lb. box, 25 c., 5 lb. box 60 .

Bug Death. It is sure death to potato, squash and cucumber bugs, currant and tomato worms, etc., also prevents blight on potato vines. Safe to handle. It is applied dry, and will not blow or wash off. I lb., I5c.; 3 lbs., 35c.; 5 lbs., 50c.; I2 1/2 lbs., \$r.00.

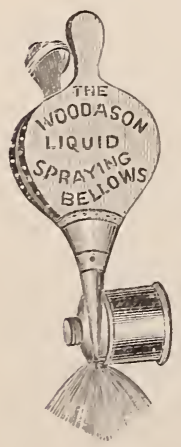

\section{Insecticide Appliances.}

Bellows, Woodason's Improved. For powder and liquid insecticides. Double cone, $\$ 3.00$; large single cone, $\$ 2.00$; small single cone, $\$ 1.00$; spraying, $\$ 1.25$ and $\$ 2$ each.

Bellows, Joosten's Magazine. For applying sulphur, fostite, slug shot, etc. Price, \$3.50.

Bellows, Houchin Powder. Large, $S_{5} \mathrm{c}$; small, $65 \mathrm{c}$.

Eureka Fumigators. For smoking greenhouses with dampened tobacco slems. Made of extra heavy galsanized sheet iron. No. I holds $1 / 2$ peck of stems, \$1.25: No. 2 holds 1 peck of stems, $\$ 2.00$; No. 3 holds $1 / 2$ bushel of stems, $\$ 2.50$; No. 4 holds $3 / 4$ bunhel of stem, $\$ 3.25$.

Bellows, Sulphur. Each, $\$ 1.50$.

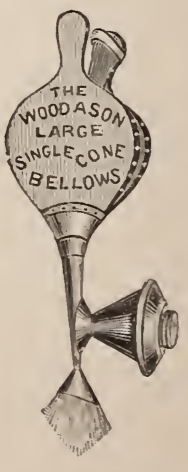

Electric Bellows. A simple practical bellows for applying paris green in the dry state. 75 c. each. 


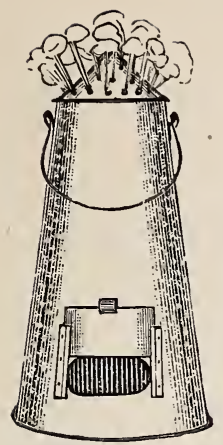

FUMIGATOR.

\section{Insecticide Appliances.-Continued.}

Perfection Fumigator. The most durable and practicable fumigator made. It has two inner parts, one forming a water tank; when in operation a vapor arises and mixes with the dry smoke from the stems, producing a dampened smoke, more dense and less injurious than from any other fumigator. No. 2 holds half bushel of stems. Price, $\$ 3 \cdot 75$.

Powder Gun, Jumbo. For applying insecticides on plants, etc. The best small powder gun on the market. The powder is ejected by the pressure of the thumb. Each, zo cents; small size, each, ro cents.

Scollay's Insect Powder Bulb. Used for applying insect powder on plants. Price, 75 cents each.

Paris Green Sifters. Made of tin, with a socket handle and perforated bottom, holding about a quart. Each, 20 cents.

Little Giant Duster. For distributing Paris Green, Hellebore, Sulphur, etc. Weighs only four pounds complete. Extreme length of duster, $4 \mathrm{ft}$. 8 inches. It keeps the poison at a safe distance from the operator and dusts potato vines as fast as you walk. Will not get out of order and with good usage will last for years. Each, \$3.50.

Farmers' Favorite Potato Bug Exterminator. 'For applying Paris Green and Plasteen mixture, Slug Shot and other insecticides. Each, \$I oo.

Leggett's Paris Green or Dry Powder Gun. An invaluable distributor of insecticides and fungicides. The distribution of the powder can be so easily regulated that half a pound or a pound of Paris Green or London Purple may be evenly distributed over one acre of potatoes. Hellebore, Insect Powder and Slug Shot can be distributed better and more economically than in any other way. Furnished with four 2o-inch tubes and several nozzles. When the four tubes are attached to the gun the distance from the ground to the end is ten feet; the powder is thrown out several feet beyond. The nozzles may be turned in any direction so as to blow the powder down or up under the leaves as desired. Price, $\$ 7.00$ each.

Eclipse Knapsack Sprayer. Made of first quality galvanized iron, and will not rust. The hose and bulb are of best white rubber, and are protected by coiled wire, to prevent breaking. The nozzle is of brass, nickel plated, and throws a spray $6 \mathrm{ft}$. wide at a distance of $12 \mathrm{ft}$. Price, $\$ 2.00$.

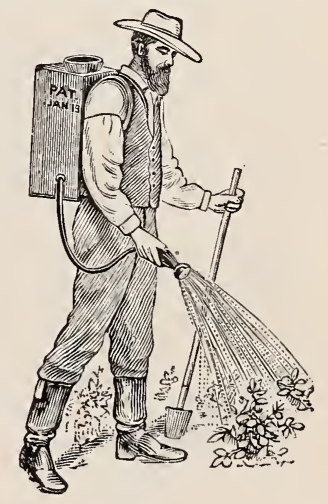

\section{Syringes, Sprinklers, Pumps, Etc.}
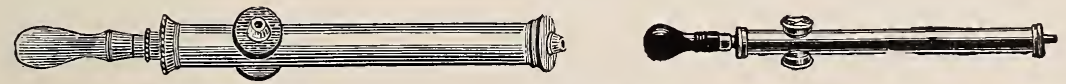

No. 10. Conical Valve Syringe. Full size barrel, 18 inches long, $1 \frac{1}{2}$ inches in diameter, with one stream and two spray roses. Price, $\$ 5.25$.

Letter “ $G$ " Garden Syringe. Barrel 16 inches long, 1 1 $2 / 2$ inches diamețer. Specially designed for applying insecticide on the under side of the leaves. Open rose syringe, one spray and one stream rose. Price, $\$ 4$.00.

Stott's Patent Syringe. An automatic insecticide mixer. The cell being charged with the insecticides, the water, on leaving the syringe, is perfectly impregnated. Barrel 18 inches long, $\mathrm{I} 1 / 2$ inches in diameter, with two sprayers and one rose spray. Price, $\$ 6.00$.

No. 12. Garden Syringe. Barrel $\mathrm{I}_{4}$ inches long, $\mathrm{I}$ inch in diameter, with jet and two rose sprays. Price, $\$ 3.25$. 


\section{Syringes, -Sprinklers, Pumps, Etc.-Continued.}

Letter $H$. Barrel IS inches long, IÍ2 inches in diameter, with one spray. Price, $\$ 2.00$.

"L" Angle. Syringe and spraver, with self-oiling piston. Barrel I6 inches long. The discharge is either in line with the barrel or at right angles. Price, $\$ 3.00$.

Zinc Syringe. Length of barrel I $S$ inches, I I/2 inches diameter, brass rose. Price, șr.25.
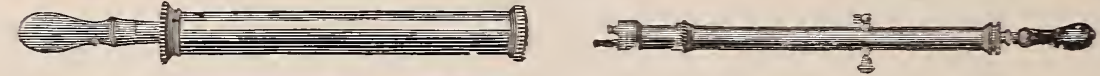

Sprinklers, Scollay's Rubber Plant. Indispensable for window gardening, sprink-

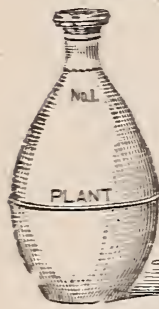
ling bouquets, clothes and other purposes where a fine spray is required. Prices: 50 cents. 60 cents and 75 cenis each.

Sprinklers, Scollay's Angle Rubber. By means of this angular neck, liquid insecticides can be sprinkled on the under side of the foliage with ease. Each, $S_{5} c$.

The Kinney Pump. For applring liquid manures. fungicides and insecticides to plants. shrubs and lawns. Price complete, $\$ 2.50$. Send for circular.

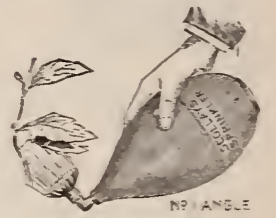

Florida Force Pump. The best and cheapest spraying pump ever put on the market. It can be used on driren wells, and will throw a continuous and powerful stream to a height of 40 feet or more. Price, $\$-.00$.

Myers' Bucket Spray Pump. These pumps are made entirely of brass, a material that is not affected by poisonous arsenites. The pumping is all done on the down stroke, the effect of which is to steady the pump, thus obriating the use of a foot-rest. They are provided with an agitator, by which the solution used in spraving is kept thoroughly mixed. Price. $\$_{3}$.50 each.

Myers' Barrel Spray Pump. Large air chamber: two discharge ports. one on each side. Price. complete with agitator, $\$ 10.00$.

Watering Pots. Galvanized Iron Watering Pots. The strongest and best flori-t

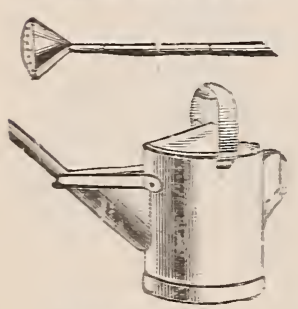

watering pot. Made of best quality iron, handle and spout riveted on. an iron band on the bottom, and galvanized after it is made. A coarse and fine copper-faced rose with each pot. Six quarts. each. \$2.00: S quarts, each. \$2.25; I0 quarts, each, \$2.50: I 2 quarts. each. $\$ 2.75$.

Watering Pots, Common. Galranized iron. much lighter constructed than the above. with short spout. Four quart. 45 cents: 6 quart, 50 cents: $S$ quart. 65 cents: io quart. 75 cents: 12 quart. S5 cents: 16 quart. S1.15.

Parlor Watering Pots with long spouts for window gardening and house use. Two sizes. 3 sent: and 45 cents ench.

Heavy Tin Watering Pots. Painted green. Made of extra strong. double thick tin. Six quart, 75 cents: 5 quart. \$1.00: 10 quart. \$1.25: 12 quart. \$1.jo.

\section{Self Closing Tomato Vine Support.}

Tomato Support-Yade of galvanized wire and will last a lifetime. Easily and quickly placed in position. They are self closing and take up little room when stored away for winter. Each. 15 cents.

Flower Support-Excelsior-Strong and durable, made of galvanized wire. Mostly used for carnations. Two sizes, \$r.oo. $\$ 1.25$ per 100 .

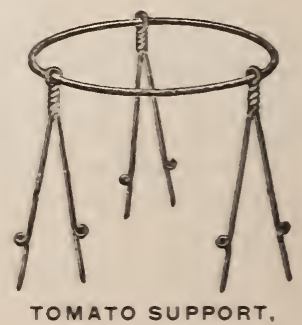




\section{Labels-Wood. For Plants, Trees, Etc}

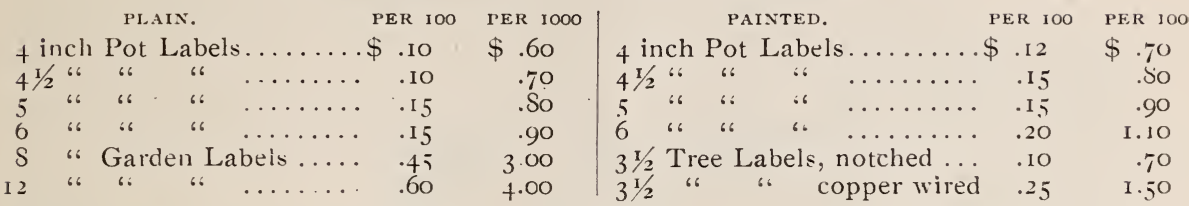

\section{Plant Stakes.-Round, Tapering, Painted Green.}

I $1 / 2$ fiet... doz. $\$ .20 \ldots$ IOO, $\$ 1.25$

$\begin{array}{llllllll}2 & 6 & \ldots & 66 & .25 \ldots & 6 & 1.75 \\ 21 / 2 & 6 & \ldots & 6 & .3 .5 \ldots & 66 & 2.25 \\ 3 & 6 & \ldots & 66 & .45 \ldots & 66 & 3.00 \\ 31 / 2 & 6 & \ldots & 6 & .55 \ldots & 66 & 3.75 \\ 4 & 6 & \ldots & 66 & .60 \ldots & 6 & 4.50 \\ 5 & \therefore & \ldots & 6 & .75 \ldots & \ldots & 5.50\end{array}$

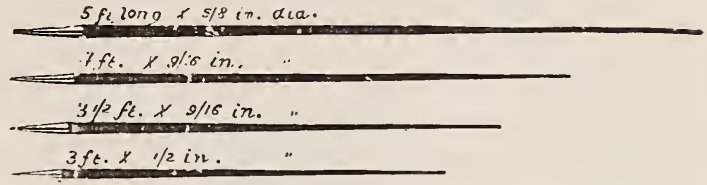

Heavy, Green Painted Round-Suitable for Dahlias. Hollyhocks. and all plants requiring strong support.

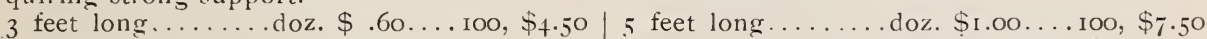

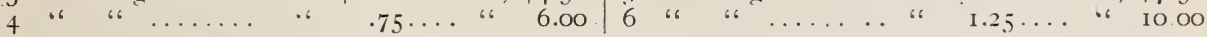

Square, Green Painted-Strong and durable.

I $1 / 2$ teet long...... doz. $\$ .15 \ldots . .100, \$ 1.00 \quad 31 / 2$ feet long $\ldots \ldots$ doz. $\$ .40 \ldots . .100, \$ 3.00$

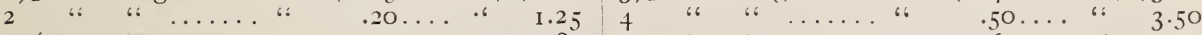

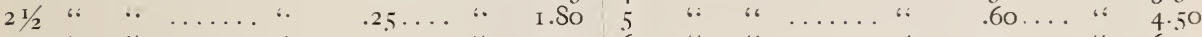

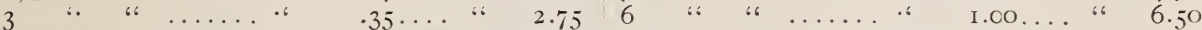

Cane Stakes-These are light, strong and durable. Thev vary in length fiom six to ten feet, can be cut to the desired length. I dozen, 20 cents; IOO, \$1.0o.

Unpainted Hardwood Stakes_Square, 2 feet.. I00, \$.25. 3 feet.. 100, \$.30.

Wire Stakes - Made of galvanized wire. 3 feet. . IOO, \$1.50 $31 / 2$ feet.. 100,\$1.75. + feet $100, \$ 2.00$.

\section{Garden Trellis.}

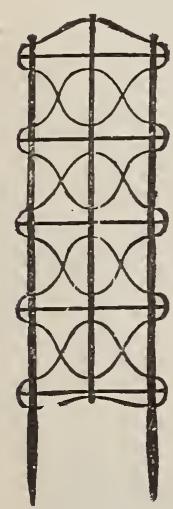

Veranda-This is by far the most ornamental and substantial Trellis made, being especially adapted to out-door use for high climbing shrubs and vines. We have eight regular sizes, but can make 10 order any given dimensions. Made of wood and rattan, and painted green. Regular sizes as follow :

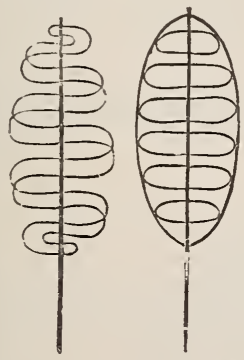

Simall Veranda, 2 feet............... each, \$ .25

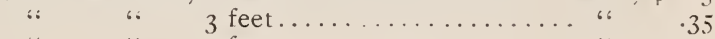

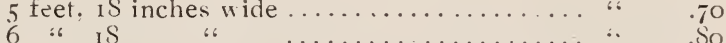

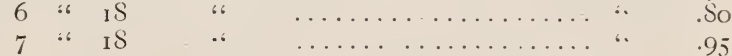

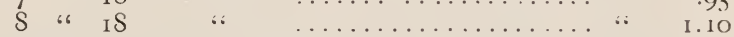

9 "6 $20 \quad$ "6 $\quad \ldots \ldots \ldots \ldots \ldots \ldots \ldots \ldots$ 6 1.25

10 "6 $20 \quad$ " $11 \quad \ldots \ldots \ldots \ldots \ldots \ldots \ldots \ldots$. 1.50

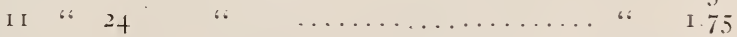

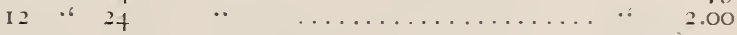

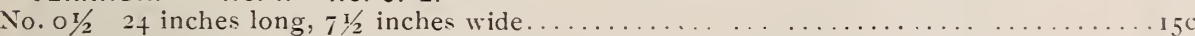

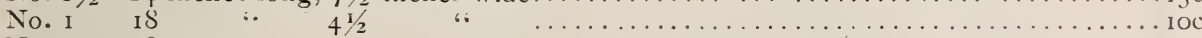

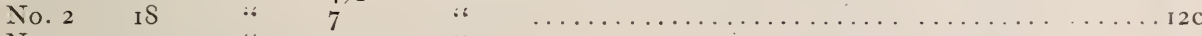

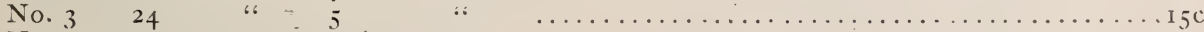

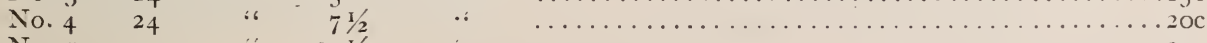

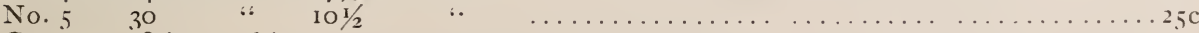

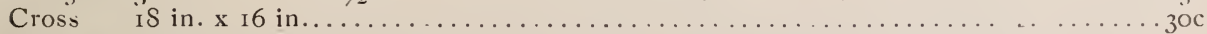

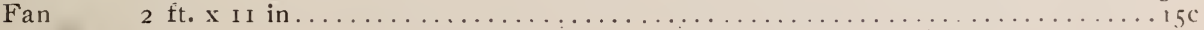




\section{Rubber Hose, Nozzles, Etc.}

High Pressure Rubber Hose-5 ply, $1 / 2$ inch, foot, 15 cents.

Eureka Rubber Hose-3/4 inch, foot, 8 cents.

Niagara Rubber Hose-Superior quality. $3 / 4$ inch, foot, 12 cents; $1 / 2$ inch, II cents.

Corduroy Rubber Hose-The finest quality, very durable: stands an enormous pressure, warranted, $3 / 4$ inch. foot, is cents.

Hose Nozzles-Fairy and Gem-Each, 5oc.

Boston Spray Nozzle - Flat copper face. Throws the water straight ahead. One of the best nozzles for greenhouse, lawn and garden. Each. 5oc.

Hose Nozzle - Rainmaker - So constructed that the spray will reach the underside of the leaves. Each, 60 cents.

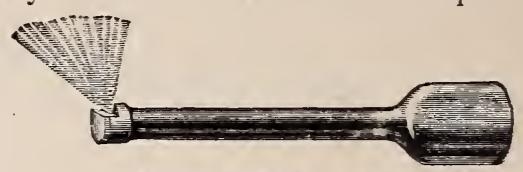

Ball Nozzle-The simplest and most perfect nozzle on the market: withstand any water pressure and never get out of order. Each, 50 cents.

Standard Revolving Lawn Sprinklers-Four arms, \$3.25: six arms, \$3.5o. Parasol, height about 12 inches, three arms, $\$ 1.00$.

Mystic Lawn Sprinkler-Throws either whole or half circle, will not clog, and very little piessure is required to revolve them. Price, 75 cents.

Stott's Sprayer-For applying insecticides; these sprayers are perfect. Each, $75 \mathrm{c}$.

Hose Menders, Hudson's-Cheapest, simplest and best hose mender on the market. Put up in boxes $1 / 2$ inch and $3 / 4$ inch size containing $I$ plyer, 6 tubes, and 20 bands, 60 cents per box. Extra bands, I 2 cents doz.; tubes, 25 and 36 cents doz.

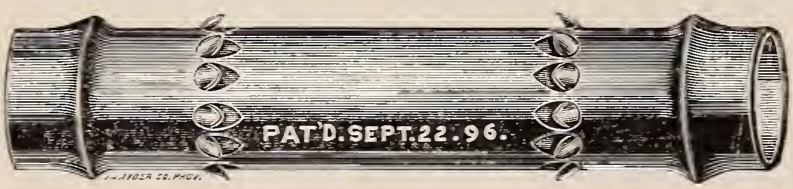

Hose Menders, Cooper'sA simple, practical mender, made of heary brass, requires no wire or plyers to adjust them. Each, Io cents. Dozen. $\$ 1.00$.

Hose Couplings-Per set.

Hose Reels-Wood-Very durable. S-inch wheels. Carry 125 feet $3 / 4$ inch hose, $\$ 1.75$. I 3 -inch wheel, carry 100 to 200 feet $3 / 4$ inch hose, $\$ 2.25$.

\section{Garden and Greenhouse Requisites.}

Baskets, Pansy, Marston's Pattern-Adjustable wooden handles, with tin fastenings on the ends. Small size, \$2.00 per 100: la rge, $\$ 3.00$ per roo.

Baskets, Strawberry-One quart, 50 cents, Ioo; \$3.00, Iooo.

Basket, Garden and Stable-5o cents, 60 cents and $\$ 2.00$ each.

Brooms-For greenhouse and garden use. Rattan and corn. Each, $4.5 \mathrm{c}$., 50c., 6oc.

Dibbers-Used in transplanting cabbage and other plants. Steel point, with wood handle, 35 cents.

Forks-Transplanting-20 and 30 cents each.

Forks-Spading-Best quality, 65 and 75 cents each.

Forks-Manure-4 tine, 50 cents ; 5 tine, 75 cents: 6 tine, $S_{5}$ cents.

Forks-Wood Stable-Hickory, 3 tine, 50 cents.

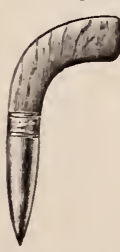

Fruit Pickers-Vade of wire, strong and durable. Each, 30 cents.

Garden Lines, Braided-Very durable, will not kink: roo ft. lengths, $50 c$.

Garden Reels-For garden lines. Each, 5o cents.

Grafting Wax-In packages, with directions for using. IO, I 5 and 25 cents.

Grafting Chisels-Each, 50 cents.

Hoes, Draw, Steel- $\delta$ to 10 inches, 30 cents each.

Hoes, Scuffle, American-6 in., 20c., 7 in.. 25 c.,

$S$ in., $30 \mathrm{cos} 9$ in., $35 \mathrm{c}$.

Dibrers. Hoes, Scuffle, Dutch-6 in., 4 Oc., 7 in., 55 c,

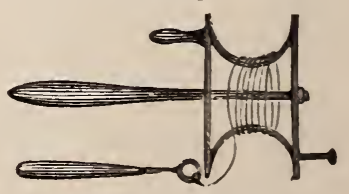

GARDEN REEL.

Hoes, Humphrey-Each, 50 cents.

Hoe and Rake Combined-Each, 25 cents.

Hoes, Warren-Each, 50 cents. 
Knives, Asparagus-For cutting asparagus under the surface of the soil. Each, 300 . Knives, Budding and Pruning-Saynor's and other makes. 5oc. to \$1.50. Knives,Grass Edging-Blade and shank solid steel. Each, 5oc.

\section{LAWN MOWERS.}

Our increased sales of these mowers amongst the florists and gardeners is the best proof we have of their superiority over the many kinds now in the market. We warrant them in every particular, and should they not prove satisfactory after a fair trial we will gladly refund the money.

The New Quaker City and Garden City with Enos' Patent Yielding Bed-knife.

This bed-knife is made of the best quality of steel, but flexible and adjusted to conveniently

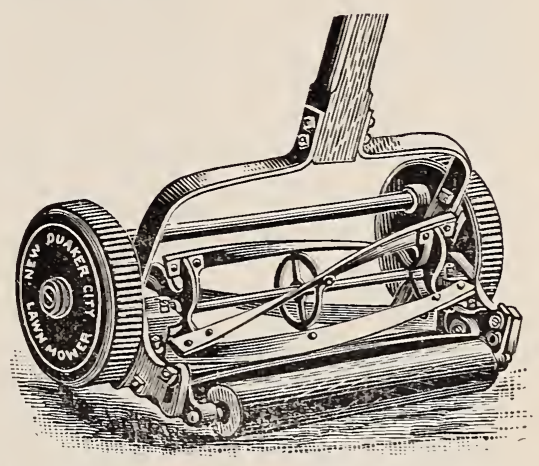
touch the revolving cutters, making the mower positively self-sharpening. This is positively the best lawn mower on the market.

\begin{tabular}{|c|c|c|c|}
\hline Garden & City, $12-i n \ldots \ldots \ldots \ldots \ldots \$ 50$ & New Quaker City, & 12 -in........... \\
\hline & $\ldots \ldots \ldots \ldots 600$ & 666 & 14 -in. \\
\hline “. & $\ldots \ldots \ldots \ldots 65_{50}$ & $\because$ & 16-in \\
\hline " & I 8 -in............ \& & “ & 18 -in . . . . . . . . \\
\hline
\end{tabular}

\section{THE "VICTORY" BALL BEARING MOWER.}

The axle of the revolving cutter turning on ball bearings reduces friction to a minimum making this the easiest machine to propel ever offered.

Price, $y_{4}$-in., $\$ 7.50 ; 16$-in., $\$ 8.50 ;$ I 8 -in., $\$ 9.50$.

\section{"NEW DEPARTURE" HIGH GRASS LAWN MOWER.}

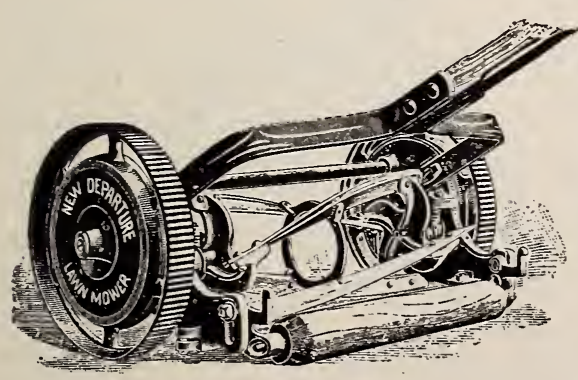

A first-class low priced high wheel mower, made for cuttiug both high and low grass, on both uneren and smooth lawns. Wheels $9^{1 / 2}$ inches high and $1 / 1 / 4$ inches wide. It has a special patented adjustable device for the cutter bar, which will prevent any unequal wear of the Dead Knife, and as the New Departure Nowers are self-sharpening, there is nothing to prevent this lawn mower lasting for years without any alterations.

15 =inch, $\$ 7.00$.

17 =inch, $\$ 7.50$

Parties intending buying a lawn mower should examine this machine before purchasing elsewhere.

We can furnish the Genuine Philadelphia Lawn Mower, when desired at lowest prices.

Lawn Mower Oil. Half pint can with oiler top. Each. 2oc. 


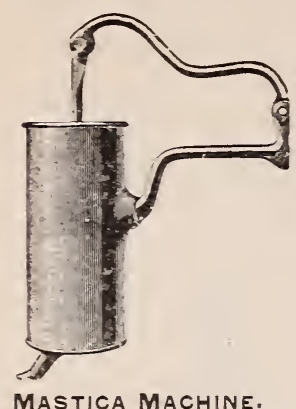

Mastica. Firglazing greenhouses, sashes, etc. Elastic. adhesive. easy to apply. Far superior to putty, as it will not become hard and brittle, but remains in a soft, pliable and elastic condition for years. Not affected by dampness, heat or cold. Used by all the leading florists in the country. Can be applied by machine or knife. $1 / 2$ gallon. 60 cents: gallon, \$i oo.

Mastica Glazing Machine. $\$ 1.00$ each.

Oilers, Zinc, with brass bottom. Each ro cents.

Plant Tubs. Made of cedar, painted green, and bound with three strong iron hoops. Drop handles.

MASTICA MACHINE.

Outside Measurements.

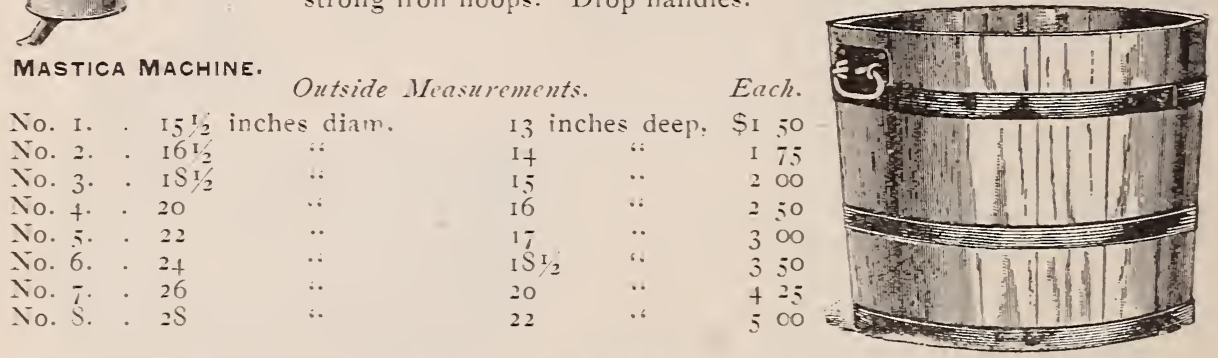

\section{OAK PLANT TUBS.}

Natural Wood Finish. Strong and Light.

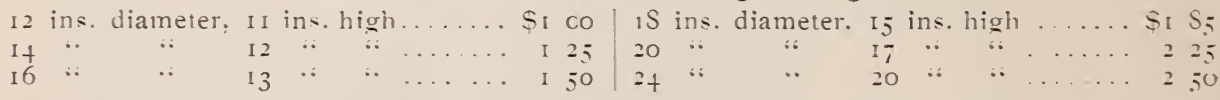

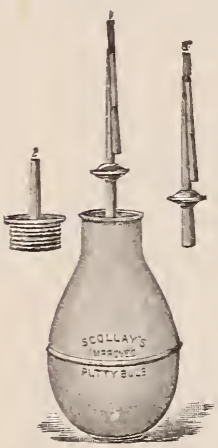

PUTTY BULBS.

Height. Sec.

$125 \mathrm{ib} . \quad 2$

$17-\cdots \quad 3$

I $S_{5} \cdots$

$\begin{array}{lll}300 & \cdots & 2 \\ 250 & \cdots & 1\end{array}$

$210 \therefore \quad 1$

400 : 2

$275 \therefore \quad 1$

550

Plant Protecting Cloth. A cheap and effectual substitute for glas on hot beds and cold frames. Largely used in place of glass for protecting plants in early spring. Promotes early, hardy and vigorous growth. Prices, medium grade, yard, Io cents: by the piece, 9 cents per yard. Heary grade. one vard. 12 cents; by the piece. Io cenls per yard.

Putty Bulbs, Rubber. For glazing greenhouse sashes. Each \$i.co.

Rakes, Lawn or Garden, Steel. Io teeth, 35 cents: 12 teeth. to $^{\circ}$ cents: If teeth. 45 cents: 16 teeth. 50 cents: IS teeth. 55 cents

Rakes, Lawn, Wooden. fo cents to so cents each.

Rakes, Steel Wire. For lawns. 5oc. to $75 \mathrm{c}$. each.

\section{GARDEN ROLLERS.}

Cast Iron.

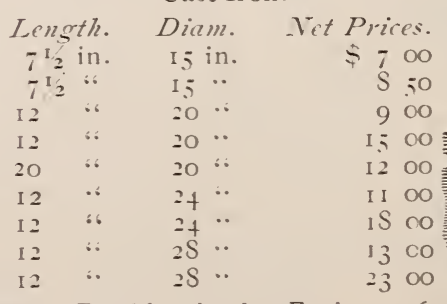

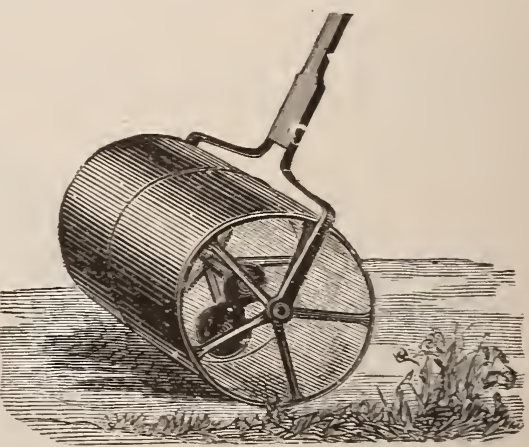

Saws, Pruning. Double edged. Each, $50,60.75$ cents.

Scissors, Grape or Vine. Nickel-plated. 6-inch, 75 cents. Scissors, Flower Gatherers'. Fur culting and holding flowers. Nickel-plated, 6-inch, go cents.

Scissors, Pruning. Nickel-plated. Without spring. $90 c$. 
Scrapers, Tree. Each, 30 cents.

Shears, Hand Pruners'. Various. 40 cents to $\$ 1.25$ each.

Shears, Grass, with Long Handles. For cutting the edges of grass borders. 9-inch blade, $\$ 2.25$; ro-inch, $\$ 2.75$.

Shears, Branch or Lopping. 2-in., \$2.00; 3 -in., \$2.50.

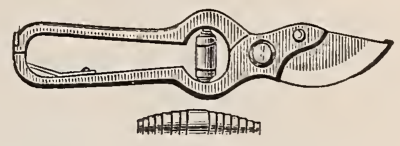

Shears, Grass. S-inch blade, $\$ 1.25 ; 9$-inch, $\$ 1.50 ;$ 10-inch, $\$$ r.75.

Shears, Hedge, Notched. S-inch blade, $\$ 1.50 ; 9$-inch, $\$ 1.75 ;$ Io-inch, $\$ 2.00$.

Shears, Sheep. Used for trimming grass borders. 25 cents to $\$ 1.25$ each.

Shears, Waters' Tree Pruning. The blade is thin, thus offering rery slight resistance to the wood in cutting. The Waters' Pruner never fails to cut the slightest twig. The thin blade of the pruner passes through the limb so easily that the grain is uninjured, and the bark left smoolh. Lenglh of pole, 4 feet, 65 cents; 6 feet, 75 cents: $S$ feet, $S_{5}$ cents; Io feet, $\$$ I.oo. Extra blades, 20 cents each.

Shovels, Steel. Round or square point, long or short handles. Each, 60 cents and 75 cents.

Spades, Steel. Long or short handles. Each, 6oc. and $75 \mathrm{c}$.

Scythes. Finest steel, all sizes. Price, 50 cents to $\$ 1.00$.

Scythes, English Lawn. Each, \$r.25.

Scythe Snaths. Ash, 65 cents; Cherry: 75 cents.

Scythe Stones. Welsh, 20 cents; others. 8 cents

Grass Hooks. Various sizes. American, 25 to 40 cents; English, each, 50 cents.

Grindstones. Best quality stone, mounted in heavy oak frame. No. $20, \$ 4.25$; No. 25 , \$5.25: No. 30. \$6.75; No. 35 , \$S.00.

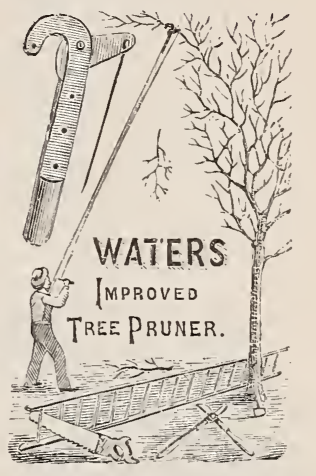

\section{Trowels, Weeders, Etc.}

Trowels, Cleves' Angle. Solid steel, very

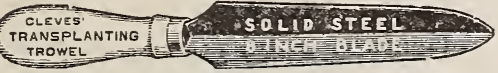
strong and useful for remoring weeds from Lawns, transplanting, etc., Daisy, 5-inch blade, each, ${ }_{5} 5$

cents; Medium, 7 -inch, 25 cents; Standard, S-inch. 30 cents.

Trowels, Garden. Forged Steel. Blade and shank are made of one piece of steel. Very strong, 6 -inch, 30 cenis ; 7 -inch, 35 cents,

Trowels, Common Garden. Various sizes, 5 cents each.

Trowels. Flat steel, 5 -inch, 15 cents.

Weeders, Noyes'. Steel, cutter diamond shape, price. 25 cents.

Weeders, Excelsior. Very useful for loowening the soil in borders and beds where a larger tool could not be used. Price 15 cents.

Weeders, Lang's. With leather band holder. Price 25 cents.

Weeders, Hazeltine. Steel blade, similar to Lang*s in shape, but larger. Each 30 cents.

Garden Tool Sets. Consists of strong, well made tools for use among flower beds, etc. Spade, hoe and fork.. Price so cents.

Garden Tool Sets. Spade, hoe, fork and rake. Price 75 cents.

\section{Thermometers.}

Self Registering. Registers both heat and cold; S-inch japanned tin case with black oxidized scale. Price \$2.50.

Hot Bed and Mushroom Bed. Pointed Brass Bottom. Price $\$ 1.15$ and $\$ 2$.

Japanned Tinned Case. 7 -inch, $50 c$.; S-inch, 6oc.; 10-inch, 7 oc. : I2-inch, \$I. 66

Incubator. 6-inch, 50 cents.

Parlor. Wood case, oak, 6-inch, 7 .5.; S-inch, \$r.oo.

Parlor. Porcelain scale, very distinct, S-inch, 90 cents : Io-inch, \$1.25. 
Wheelbarrows, Garden. Made of selected stock and hearily braced, painted, or natural wood varnished. No. $1, \$ 2.75$; No. $2, \$ 2.75$; No. 4 , $\$ 3.00 ;$ No. $6, \$ 3.50$.

Wheelbarrows, Garden. Custom made. Extra selected stock. Medium size, No. 3, \$6.0o. Large size, No. 4 , \$S.oo.

Wheelbarrows, Canal. One size. Each \$1.50, \$1.75.

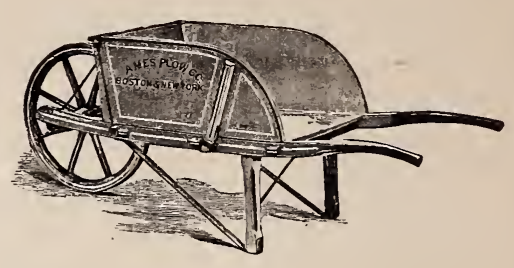

\section{Tying Materials, Florists' Supplies, Etc.}

Roffea. The best material for tying plants, being very soft, strong and pliable. Per lb. I 5 cents.

Silkaline, or Smilax Thread. Largely used for stringing smilax and in bouquet work. Spools 25 cents each.

Twine. Green cotton used for stringing smilax, etc. 40 cents per lb.

Twine. White cotton, best 4 -ply. 25 cents per $1 \mathrm{~b}$.

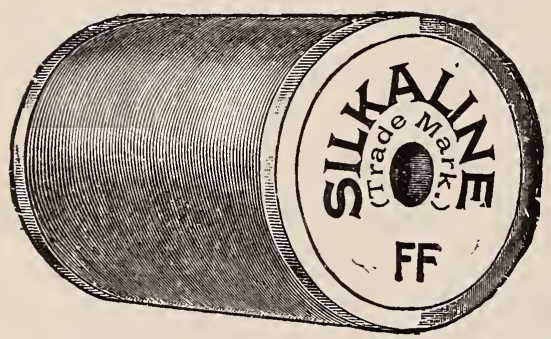

Twine, Jute. For tying plants and regetables, soft and pliable. 12 cents per $1 b$.

Twine, Hemp. Various sizes. Ball, Io to $20 c$.

Tarred Yarn. Low-priced material for tying shrubs, etc. II cents per Ib.

Tarred Marline. Warranted best hemp. Better quality than the above. I lb. balls, 15 cents.

Tinfoil. For florists' use. Lb., 15 cents.

Bouquet Wire. Biight. Nos. 22 and 24,9 and 12 -inch lengths. Lb., 15 cents.

Bouquet Wire. Bright. No. 36 , fine, lb., 25 cents.

Toothpicks. Used in stemming flowers. Box ro cents.

Glazier's Points, Van Reyper's. For Greenhouse use. The only durable and reliable points on the market made of steel wire and galvanized; prevents glass from sliding; no rights and lefts; can be used on either side of the sash bar; per box of $1,000,60$ cents. Pincers for driving these points, 40 cents.

Paper, Tissue. Used in packing plants and flowers for shipping. Quire, o5 cents.

Paper, Waxed. Size I4xi8. Lb., 30 cents.

Indelible Garden Pencils. Black, for marking wood labels. Each, Io cents.

\section{Cast Iron Bouquet Holders for Cemetery Use.}

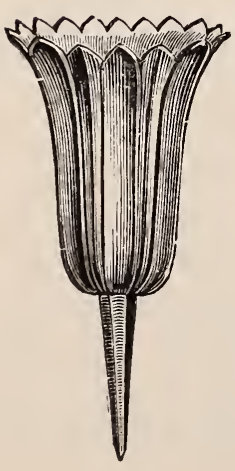
Tulip Shaped. Green and Bronzed.

No. 4 small size.................... each 20

" 5 medium size................ " 25

" 6 large size.................. " 30

\section{Tin, Green Painted.}

No. I small size $31 / 2 \times 61 / 2$ in ........... " 10

" 2 large size $4 \frac{1}{4} \times 81 / 4$ in ............ " 15

\section{Folding Wire Plant Stand.}

These are made of steel wire neatly painted green and bronzed. When not in use they can be folded together and put away in a small space

2 Shelf Stand, 27 inches high...... each \$2 75

3 Shelf Stand, 36 inches high..... " 350

5 Shelf Stand, double............ " $\quad 550$

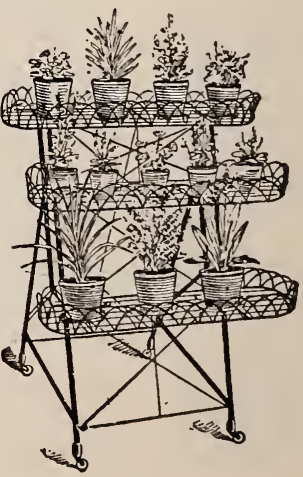




\section{Standard Flower Pots.}

\section{Measurements From Inside to Inside. Width and Depth Equal.}

On orders to the amount of two dollars and over, we make no charges for crates or packing. On orders for less than two dollars, packing charged at cost.

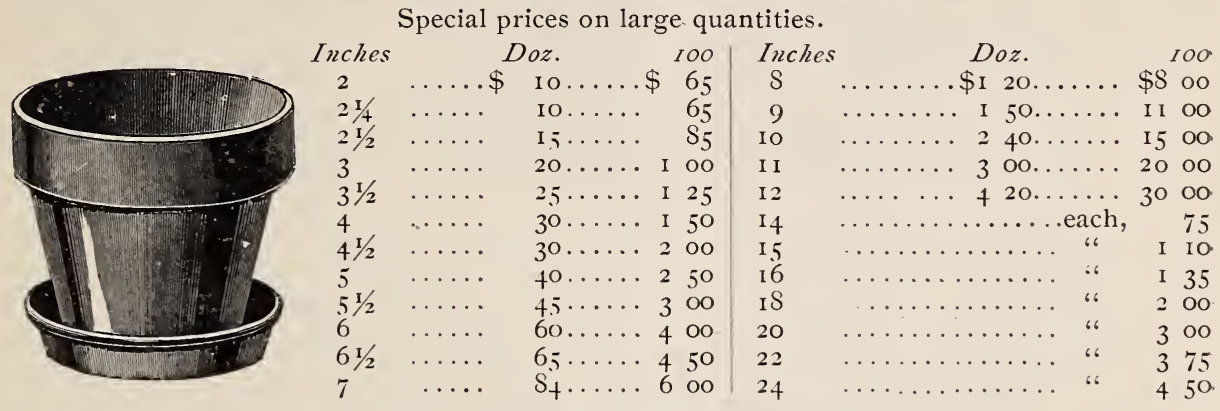

Flower Pot Saucers.

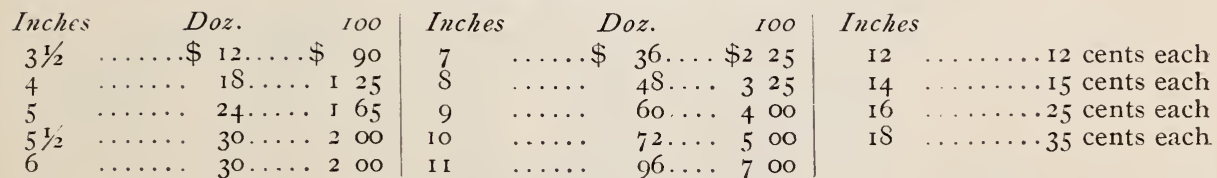

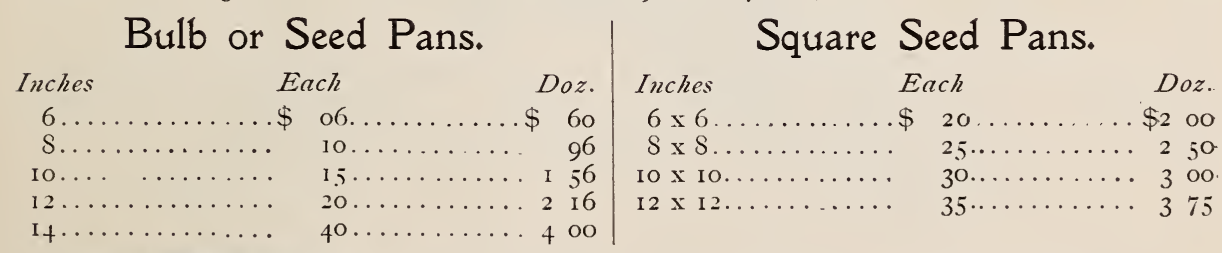

\section{Water Proof Flower Pot Saucers.}

One will appreciate the value of these new saucers over the ordinary flower pot saucer, as they do not absorb moisture and are indispensable when decorative plants are placed on the table, carpets, etc., thus preventing all injury by moisture.

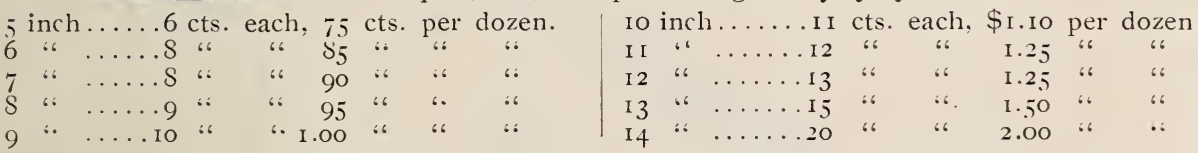

I 3 in., with castors, 65 cents each; 17 in., with castors, 75 cents each.

18 " " " 10 " 100 " 20 " "

\section{Neponset Paper Flower Pots.}

Are manufactured of water-proof paper, unbreakable, handsome, light and cheap. They are made so as to admit plenty of air to the roots and to give sufficient drainage.

Not less than 1000 at 1000 rate.

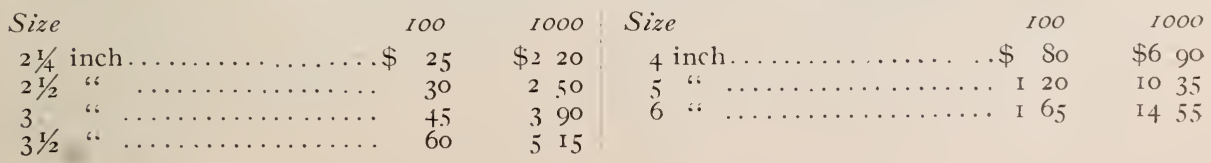




\section{THE "IRON AGE" TOOLS FOR 1899.}

\section{Hand and Horse.}

The "Iron Age" line of tools is the most complete and up-to-date on the market, and users are finding that they are good things "to tie to;" they seldom disappoint. We offer them not only as the best, but as the cheapest. We catalogue only the leaders, but shall be pleased to mail catalogue showing full line. Send for it.

\section{The "Iron Age" Double Wheel Hoe.}

This new hoe is built with light steel wheels, 16 inches in height and with the high arch is capable of working 20 -inch plants. The frame is tubular, coupled to malleable castings. giving great lightness with freedom from breakage. The wheels can be

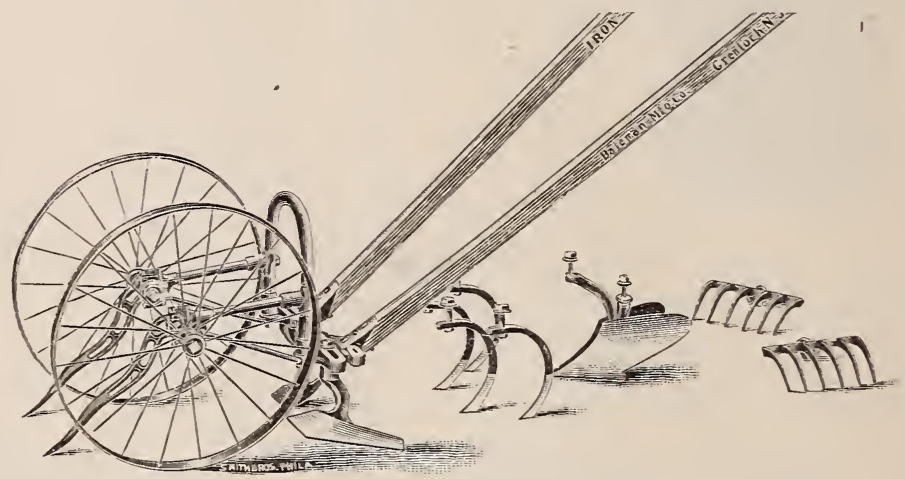
quickly adjusted in

height without entirely remoring the axle nuts, and by the use of the extra axle sent with each tool it can be made into a perfect single wheel hoe. The hoe is fully equipped with side hoes and plows, finely shaped and polished, steel cultivator teeth and a pair of rakes

Price Complete........................\$6 oo

“ with side hoes only................ 3 s

\section{THE "IRON AGE" COMBINED SEED DRILL AND WHEEL HOE.}

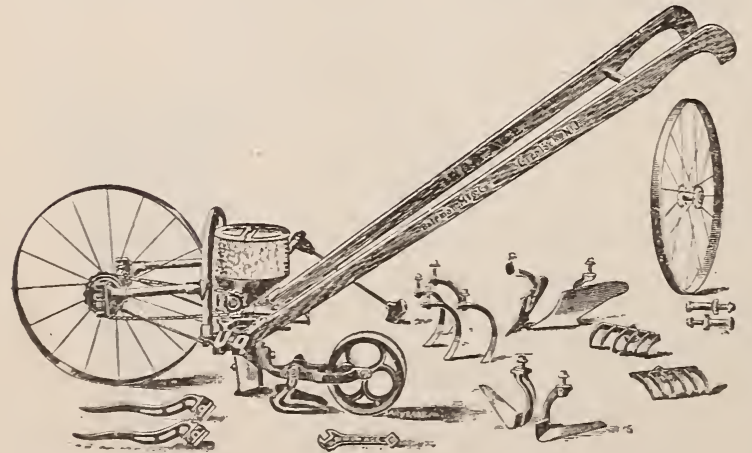

Price, Combined Drill and Hoe..

“ Drill only.
The Drill attachment is simple, easily atlached, and requires but two bolts to hold it in place. The seed slide and index is similar to that used on the "New Model" seed drill. The opening plow is adjustable and reversible. The combined drili includes all the attachments shown with the "Iron Age" double wheel hoe, and is a tool-house in itself. It plows, levels, furrows, sows covers, rakes. etc. 


\section{THE “IRON AGE" SINGLE WHEEL HOE.}

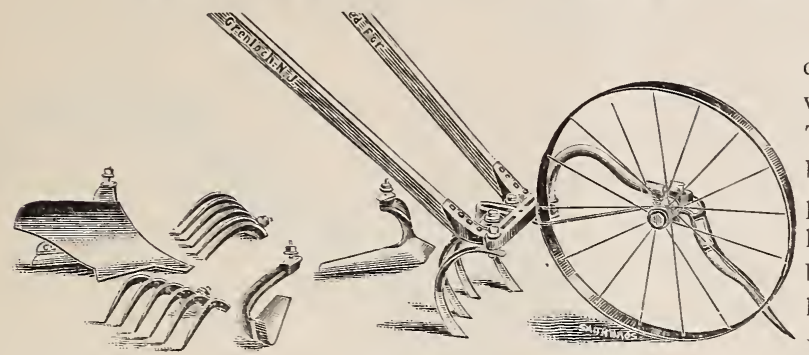

For the small kitchen garden we consider the single wheel hoe as being preferable. The work is done principally between the rows, although plants of small growth can be hoed on both sides at once by placing the wheel on the left side. With this single wheel tool spaces of exceed-

ingly narrow width can be worked eren using but one cultirator tooth.

Price, complete, \$4.50. Price, plain (hoes only), \$2.75.

\section{THE "IRON AGE" HILL AND DRILL SEEDER.}

This seeder is offered to the public after careful experiments in the field. It has embodied in it a number of new principles which make it superior to any other seed drill in the market. The wheel is made of steel, is 16 inches high and has a 2 -inch tread. The opening plow is positively clog proof. By a thumb-screw it can be instantly adjusted in depth. The hopper is low, therefore the delivery of

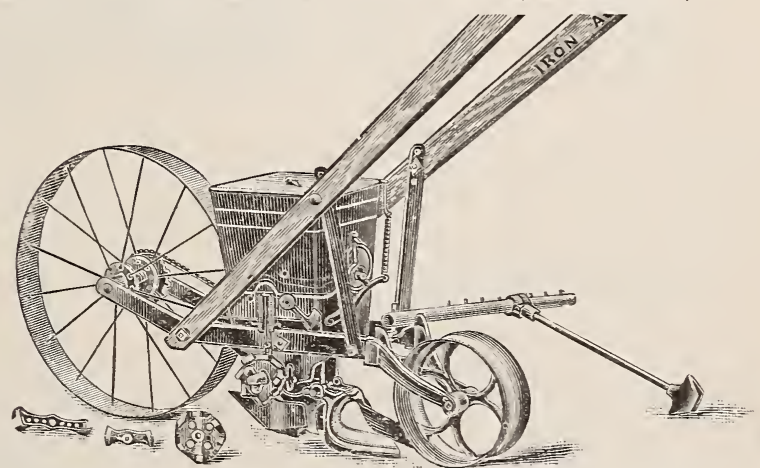
the seed is close to the ground, thus making possible accurate spacing. The capacity of the hopper is four quarts. It will drop at $4^{1 / 2}$ inches, 6, 9, I2, I 8 and 36 inches apart. By dropping a small cam back of a lever the tool is changed to a row drill.

Price. .

$\$ 1000$

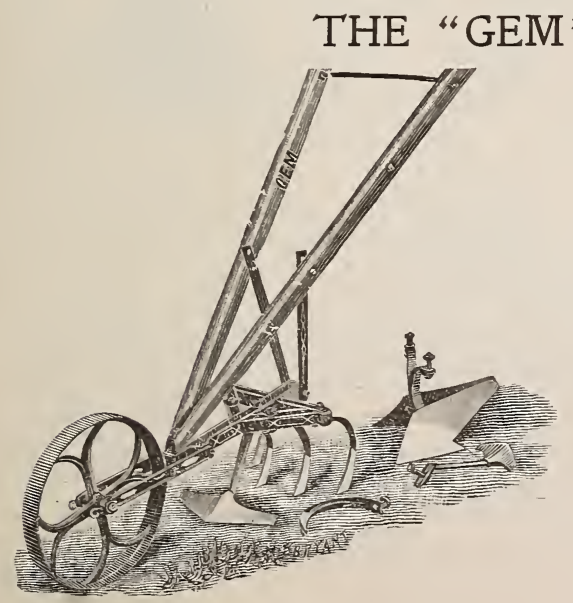

\section{WHEEL HOE.}

There can be no greater proof of the popularity of a tool than the continued demand for it. Among the many" "Gem" Hoes we have sold we are not aware of a single instance in which ther have failed to give satisfaction. It has a set of Adjustable Steel Teeth, two Push Hoes and two small Plows. We can furnish to anyone desiring to change the single into a double wheel hoe the necessary attachments.

Single Wheel Complete...........\$+ $\$_{+} 00$

“ “ less Plows.......... 325

Double Wheel attachment to change

single wheel hoe to double wheel

hoe..................... 150 


\section{THE "NEW MODEL" SEED DRILL.}

The improvements in this seed drill are worthy of special notice. The flow of seed from the diamond shaped hole can be quickly moved to fit any size seed by a simple contrivance. This is unlike other drills, which are confined to certain sized holes in the dial plate and with no means of varying it. The flow of seed can also be instantly stopped by a swinging cut-off, instead of a slide, as on other machines. The flange of the wheel is wide, and there is a marked advantage over other drills in the manner of attaching the handles. We warrant these superior to any drill in the market.

Price.........\$6.co

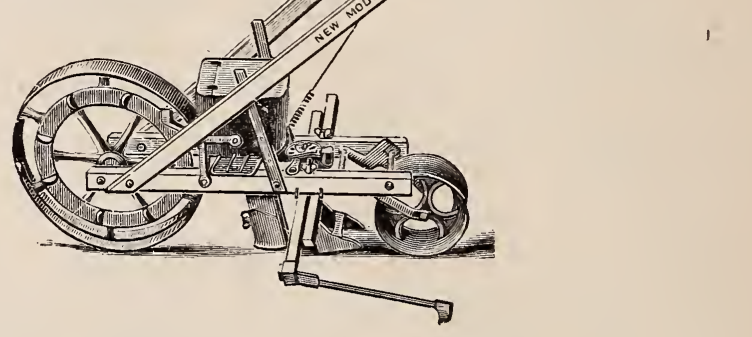

THE "JEWEL"

\section{DOUBLE WHEEL HOE AND CULTIVATOR COMBINED.}

The "Jewel" is capable of being quickly adjusted in depth or width of working, or height of handles. It is provided with four slender stirring teeth, each made of one piece of steel, unexcelled for thorough work. One pair of side hoes, particularly in ${ }^{-}$ tended for use among small plants; also, a pair of plows for throwing to or from the row, or for opening furrows.

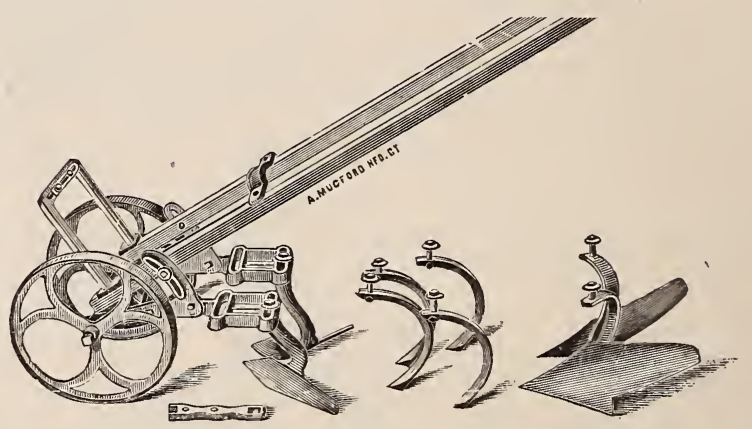

Price . . $\ldots \$ 500$

\section{The "Iron Age" Wheel Hoe.}

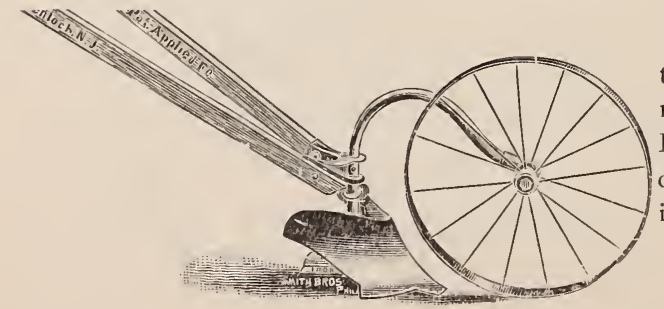

To the owners of small gardens this tool is most useful. With it the furrows for manure or seed can be opened or covered. It is very light, and can be adjusted in depth, and we think we are right in calling it a "little beauty."

Price .$\$ 2 \quad 25$ 


\section{The No. 7 "Iron Age" Horse}

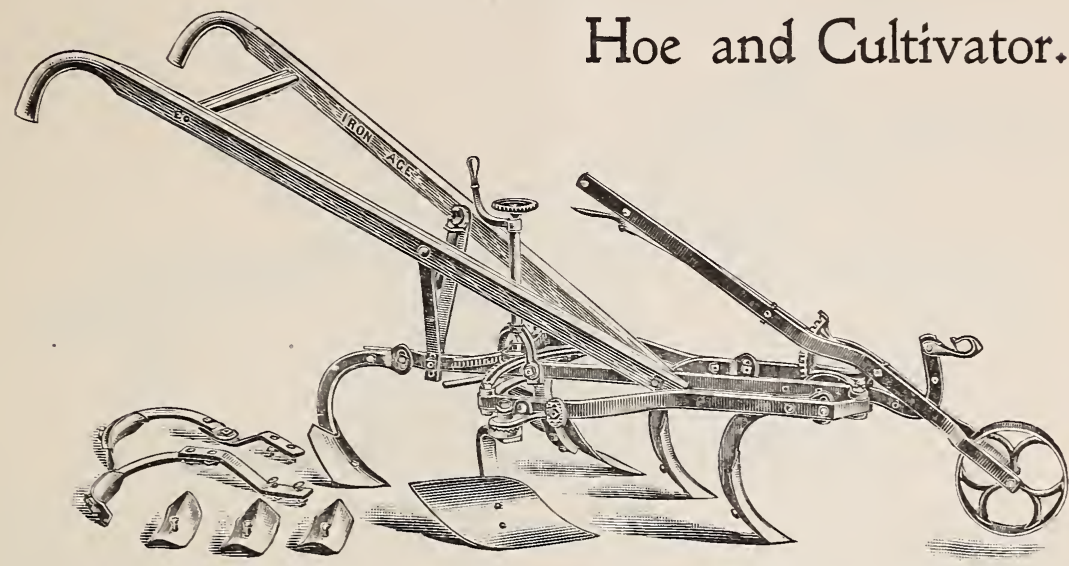

In our No. 7 "Iron Age" Horse Hoe we offer to the public a derice, which without question is the best expander yet introduced. The tool is at all times rigid, this being attained almost as easily and quickly as is the case in an ordinary lever expander. It is in principle a combination of the lever expander and the old strle clamp expander, maintaining the adrantages and overcoming the disadrantages of both. By simply releasing the wheel and moring the crank to the right or left the cultivator is widened or narrowed. $\mathrm{By}$ this device one side of the cultivator may be set nearer the middle bar than the other.

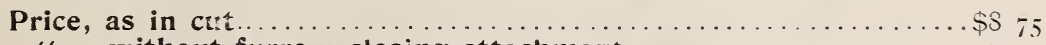

" without furrow closing attachmert .............. 750

“ with plain wheel and less furrow closing attachments ... $\quad 7 \quad 25$

\section{"Iron Age" Combined Harrow and Cultivator.}

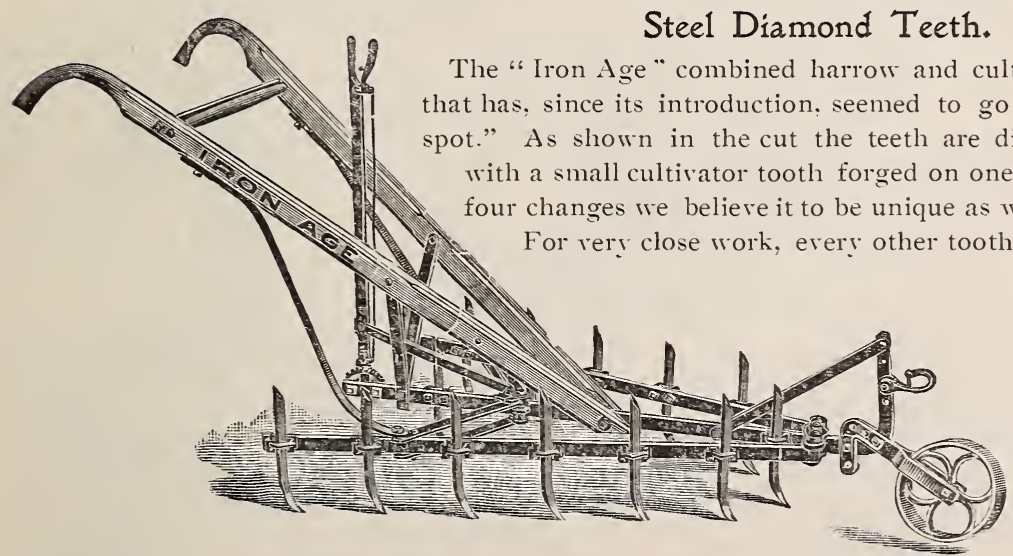

The "Iron Age" combined harrow and cultivator is a tool that has, since its introduction, seemed to go to the "right pot." As shown in the cut the teeth are diamond shaped, with a small cultivator tooth forged on one end. With its For very close work, erery other tooth can be quickly removed. The diamond pointed teeth are reversible and can be adjusted as spike tooth, smoothing or common cultivator. In common with all good things, this tool has numerous inferior imitations. but for solid quality, design or finish, is not approached by them.

Price, without wheel.....\$4 $\$ 5^{\circ}$

With wheel and lever.....\$5 oo 


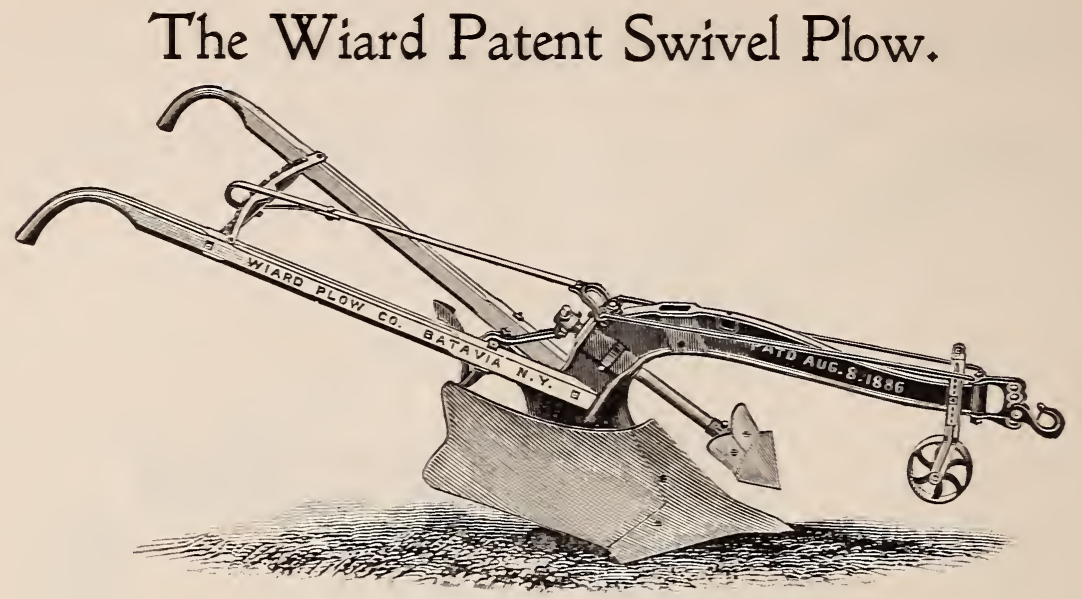

In turning qualities these plows cannot be excelled. Any objections, real or imaginary. to the use of a swivel plow, on level land, are entirely overcome by the use of the patent adjustable cleris by which the operator "lands his plow" as desired, in a moment's time. For level land or side-hill these plows do the finest work and ther have come to be the recognized standard of plows for this class.

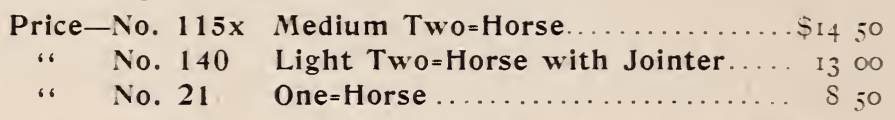

\section{DOE'S IMPROVED PLOW.}

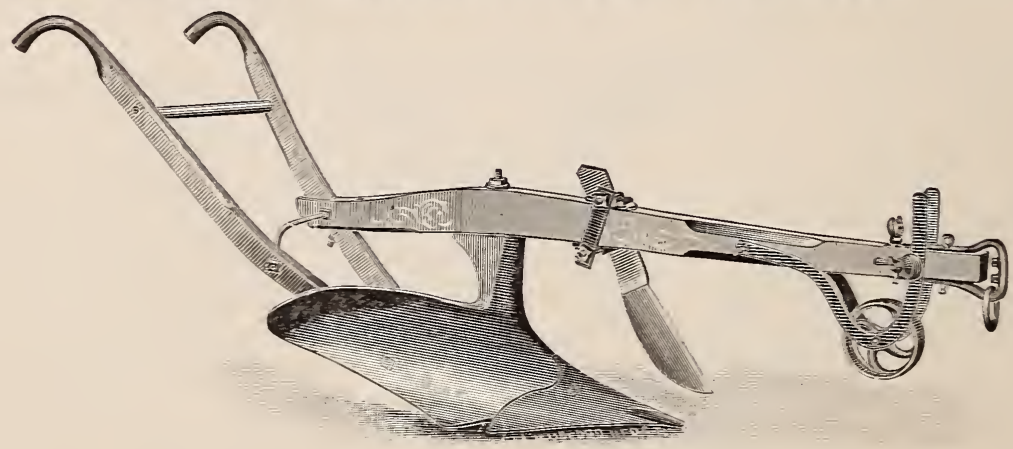

This plow is now made from improved patterns which, while retaining the original form of the mouldboard, are made with higher standards of such form that clogging is entirely obviated.

Owing to the position of the landside with the convex mouldboard it turns a diamond shaped furrow, laying it very flat, covering up all grass, weeds. etc.. without using a jointer.
E0. Furrowing.
Plis.
WhEEL.
WHEEL
E1. One=Horse............. 500
E2. Light Two=Horse......... $65_{50}$
E3. Two $=$ Horse ............. 750
$\$ S \infty$
$\$ 950$
$900 \quad 105^{\circ}$
E4. Two or Three=Horse ....... 9 co
IO $50 \quad 1200$ 


\section{Vermonter Steel Mouldboard Plow.}

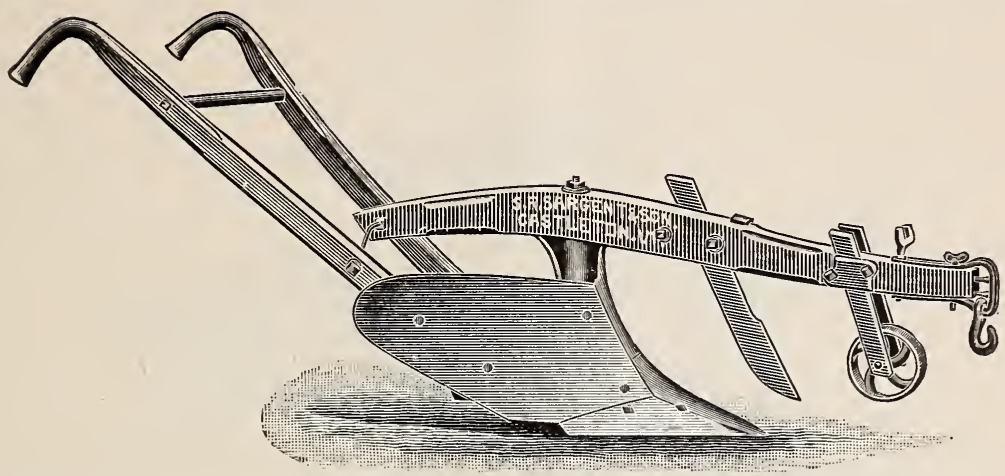

These steel mouldboard plows are made in two sizes, are warranted to scour in any soil and to stand in hard, rocky ground or among roots. They are a capital plow for breaking or plowing bog meadows, old pastures, etc. We can furnish for this plow a steel-edged point for use in plowing wild grass, roots, etc. It cuts under as wide as the plow turns. Furnished with jointer or straight cutter, as desired.

No. 9. Two $=$ Horse $\ldots \ldots \ldots \ldots \ldots \ldots \ldots \ldots \ldots \ldots \ldots \ldots \ldots \ldots \ldots \ldots$

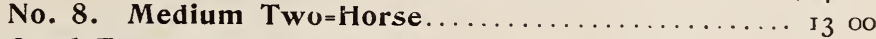

Steel=Edged Point, extra................. I 50

Deduct $\$ 1.50$ each if without Wheel or Cutter.

\section{The Oiiver Chilled Plow.}

The excellent qualities of these plows and their appreciation by the practical and intelligent farmers who use them, has induced us to add them to our list of plows. They have a centre draft, run light, will do first-class work in sod or stubble, and are economical in repairs. Prices furnished upon application.

\section{The Syracuse Sulky Swivel Plow.}

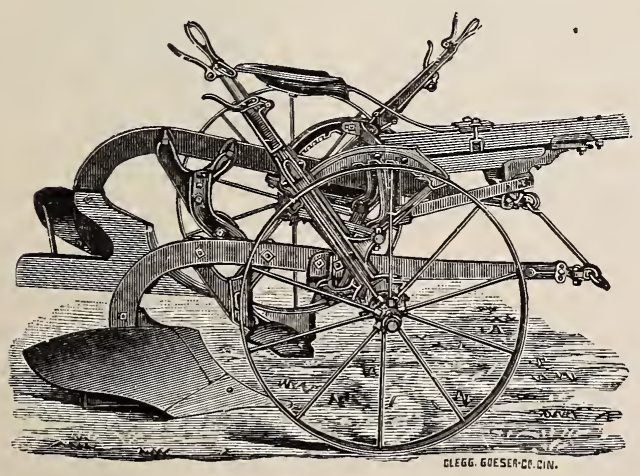

This plow has two separate beams with a plow attached to each. When one plow is in the furrow the other is raised high out of the ground. It has an automatic adjustable pole, which aroids all side strain on the team, and enables the ploughman to regulate the width of the furrow. The steel mouldboard scours in any soil. A trial of this plow will convince any one of its superior merits. Send for circulars.

Price, with Neck=Yoke, Whiffletrees and Evener, \$45.00. 


\section{"Acme" Pulverizing Harrow, Clod Crusher and Leveler.}

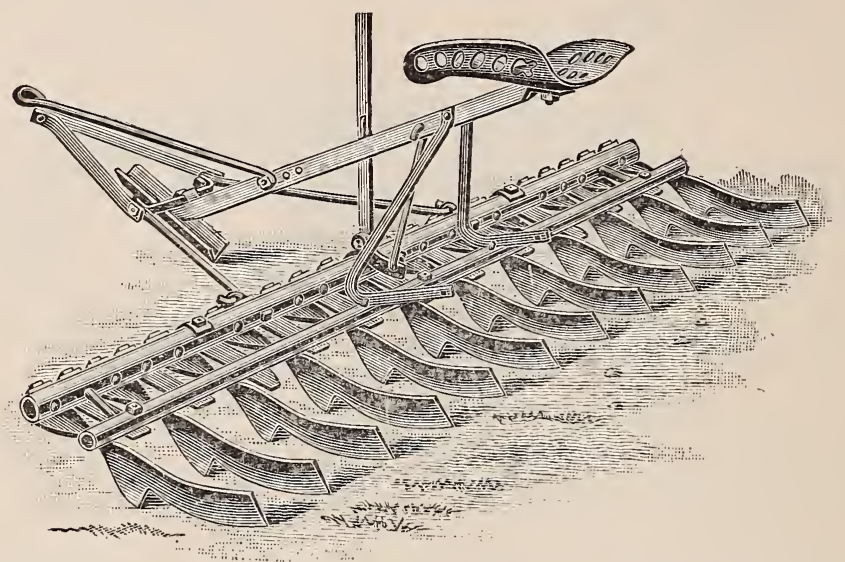

The Cheapest and Best Riding Harrow in the World.

The Acme is not a special tool as is generally supposed, but as its name implies a general purpose harrow that will crush, cut, lift, turn, smooth and level, all in one operation.

This Harrow is adapted to both heavy and light soils. While very Strong, it is extemely Light, and is therefore susceptible of doing light surface work, such as finishing off for seeding, working onion beds, truck gardens, etc., which heavy harrows cannot do because of their great weight. When covering grain or doing heavy work the No. I7 may be weighted with 25 to 60 pounds, in the shape of a bag of earth, log, or piece of railroad iron, and when so weighted it will do as Thorough Execution in Hard Soil as the Heaviest Styles.

A variety of sizes are made, working 3 feet to $13 \frac{1}{2}$ feet wide, adapted to small as well as large farms, to the orchard, vineyard and garden.

\section{PRICES.}

Size ... G, One-Horse Cultivator ....\$ S oo

" ... H, One-Horse Harrow....... 13 oo

Size No. 20, Two-Horse Walking Har-

"No. I7, Two " " (illus.) 15 oo row ................... : No. IS, Four-Horse Harrow .... 30 oo

\section{THE B. \& G. IIVPROVED SPRING TOOTH HARROW.}

As now made this is a tool that for completeness, simplicity and durability and ease of working has no equal. Made of all steel and malleable iron, its strength and lasting qualities cannot be excelled. The draw-bar attachment is such that with the rear attachment there is no lateral or side-to-side motion. Distance between the frame such that no trash can collect, and the arrangement of the teeth is such that no two teeth track or line up.

PRICE ON APPLICATION. 


\section{THOMAS STEEL DISC HARROW.}

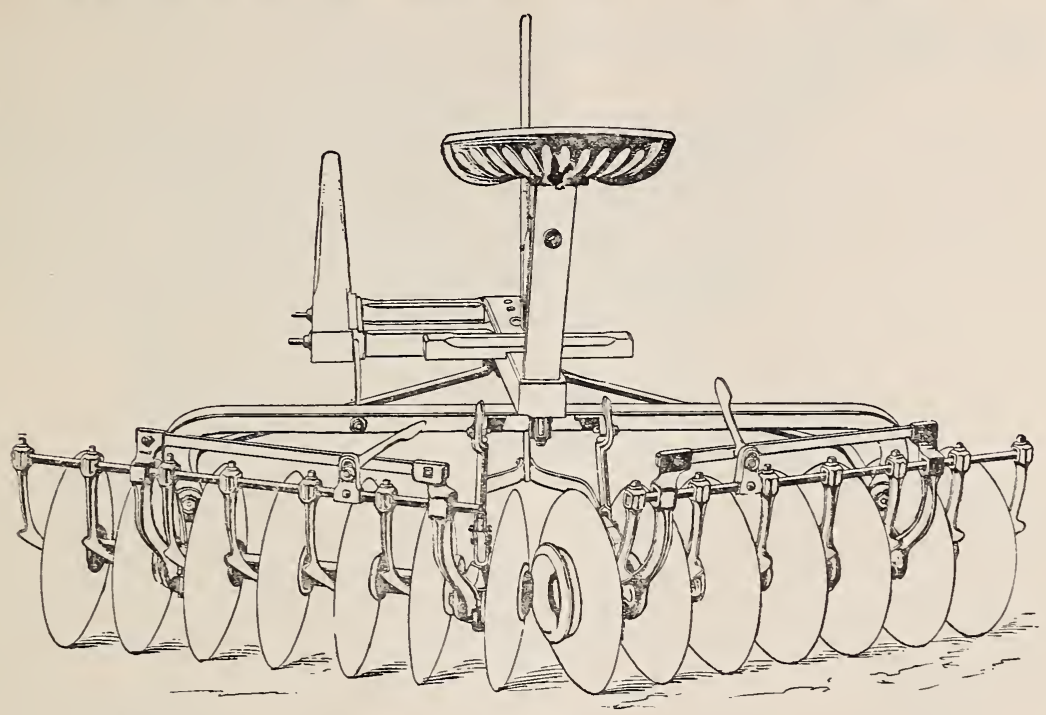

The Thomas Disc Harrow has a steel beam, square Iron Axles, Steel Seat Support, Steel Discs, almost a solid Steel Harrow; and is the most durable Disc. Harrow made, the Tongue and Whiftletrees alone being of wood.

It has case-hardened boxes, easily oiled, and sand and dirt-proof. The Thomas Harrowwe offer with first-class improved Scrapers which fit the Disc closely when wanted. Practical use of this Harrow has proven it the lightest draft, simplest. strongest and capable of doing the best work.

Price, with Scrapers, Neck=Yoke and Double Trees, $\$ 2+00$

\section{Star Reversible Smoothing Harrow.}

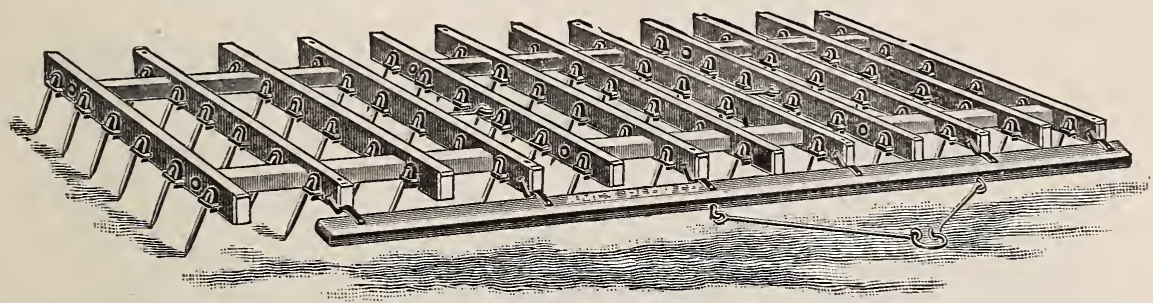

This harrow is so constructed that the teeth draw from one side of the harrow straight and from the other side slanting, as shown in illustration. It is the best harrow made for the cultivation of growing crops, as well as for seeding and other uses.

NET PRICES.

Two Section, with 48 Teeth.................. \$10 oo

Three “ " 72 " (illustrated)........ 1200 


\section{Eclipse Improved Corn Planter and Fertilizer Distributor.}

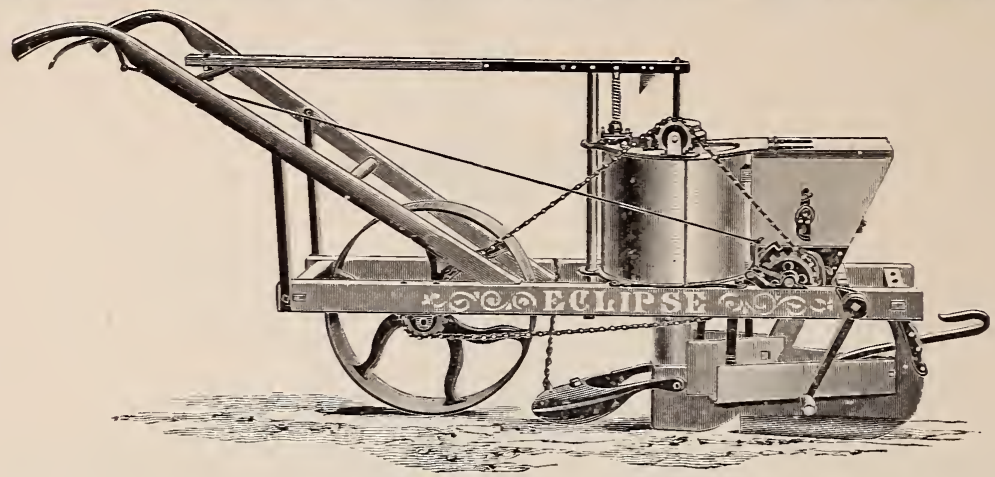

It is the only planter that will accurately distribute all commercial fertilizers wet as well as dry. pulverized hen manure, plaster, ashes, etc., in given amounts per acre in hill, drill or check. The seed is deposited in the centre of the furrow made by the plow, which is constructed with concave places on each side in front of seed gate. These form beads of moist earth which are cut off by knife edge just back of seed gate and fall on the seed. The fertilizer is then dropped on each side of the seed. The planter will drop in hills from 6 to t5 inches in distance. All parts are strongly made and the planter is adapted for use on rough and stony land.

Price.. $\$ 2200$

\section{SHERWOOD'S STEEL HARNESS.}

This harness requires no whiffletree, no long tugs, nothing in the way around the horse's heels, nothing to bark the trees and the team will work easier and better. Plowing in an orchard with one of these harnesses is a pleasure compared with the old way.

Price ...............................

\section{The Crown Seed Sower.}

For Sowing Clover, Herds-Grass, Red Top, Hungarian, Etc.

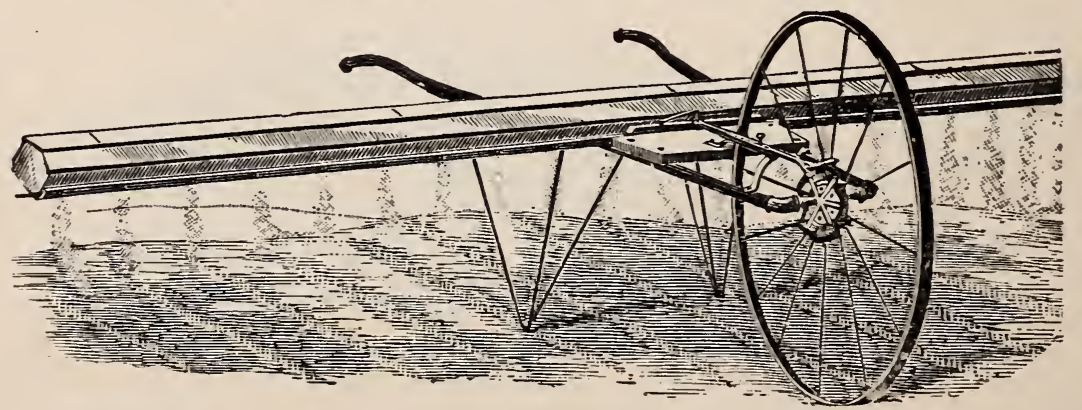

No farmer who sows grass seed can afford to be without this simple and effective machine. Quantity can be gauged from two to twelve quarts per acre. Sows twelve feet wide, and as accurate as a force feed drill. Runs light, weighs $35 \mathrm{lbs}$., will sow from fifteen to twenty acres perday; can be used in wet, dry or windy weather; it is made and finished in a superior manner.

Price............................... \$9 $\infty$ 


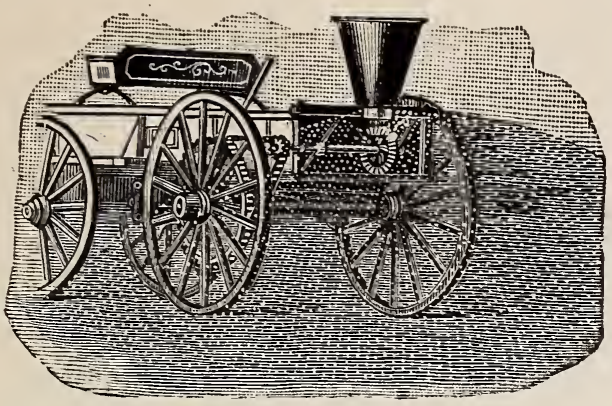

\section{STROWBRIDGE} Broadcast Seed Sower.

Sows grass seeds, oats, barley, rye, etc., and fertilizers. This machine is readily attached to the tailboard of a wagon. Sows eighty acres of grain a day, better and faster than any other method; perfectly simple.

Price, complete........\$10 oo

\section{Pearce's Improved Cahoon Seed Sower.}

\section{For Sowing Wheat, Barley, Oats, Buckwheat, Rye, Grass Seed, Etc.}

Sow's from four to eight acres per hour at a common walking gait, throwing out wheat a distance of forty feet wide. These machines are the acknowledged superior to all others of their class. and by their use a saving of four-fifths the labor and one-third the seed can be effected.

Price $\ldots \ldots \ldots \ldots \ldots \ldots \ldots \ldots \ldots \ldots \ldots \ldots \ldots \ldots \ldots \ldots \ldots \ldots \ldots \ldots$

\section{THE "ECLIPSE" WEEDER.}

This weeder is new this season. It has thirty-nine $\frac{11}{3} \frac{1}{2}$ round oil tempered spring steel teeth which at their upper ends are formed in loops, and are held firmly to the bars by malleable holders. The shafts are adjustable to the size of the horse. By keeping the horse between the rows and raising the teeth that come over the plants and adjusting the others to the profile of the ground thorough work can be done, and this weeder can be used after all other kinds have to be laid aside.

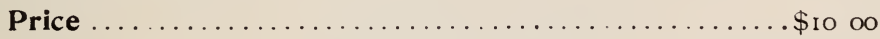

\section{The Wiard Hand Corn Planter.}

The only hand planter that drops the seed first into a receptacle and then into the ground, instead of directly from the magazine, thus insuring uniform depth for every hill. Plants as fast as a man can walk, and with more precision than is possible in the old way. The depth of plant-

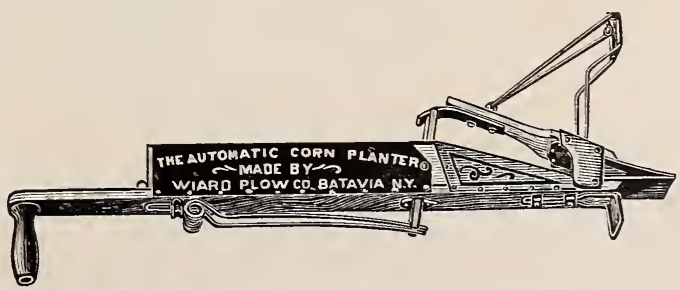
ing is regulated exactly to suit the operator, by raising or lowering the adjusting slide. It is by far the best hand planter made.

Price 


\section{The Improved Robbins Potato Planter.}

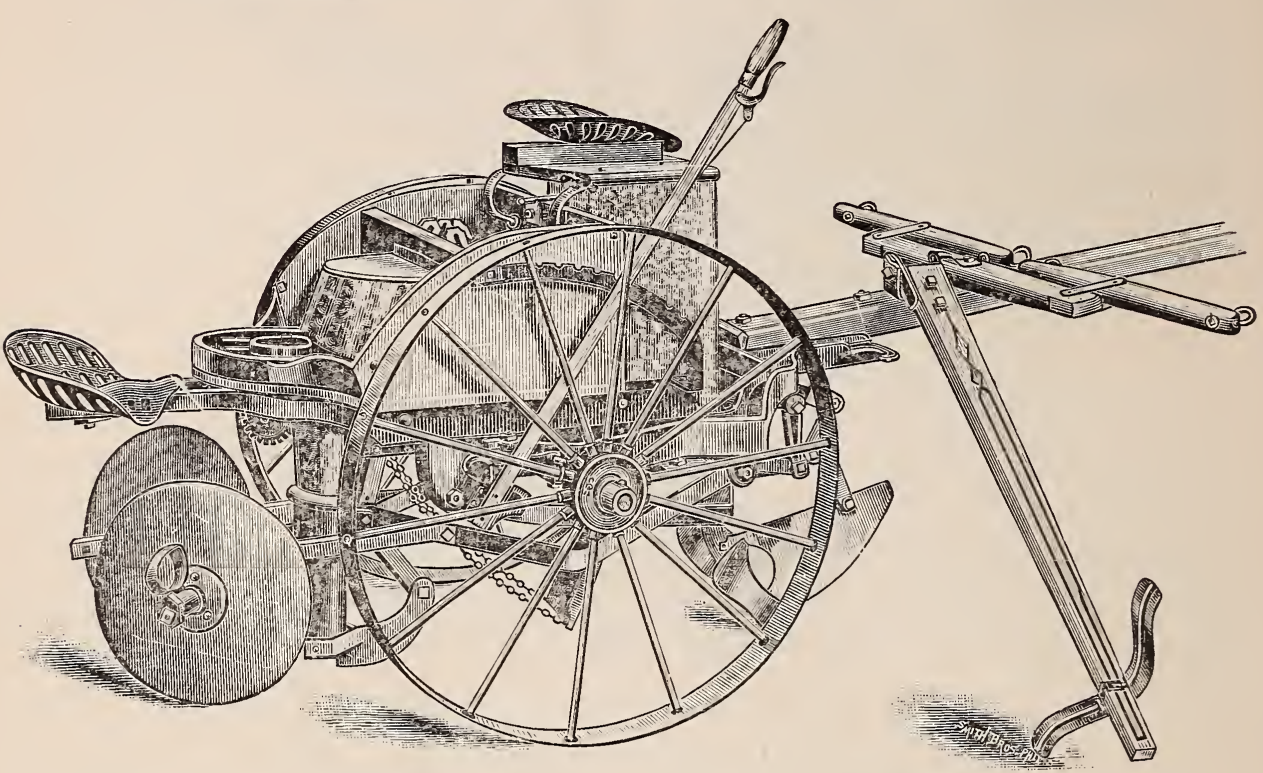

The operation of the planter is simple. The opening plow throws out a free furrow; immediately following comes the deposit of fertilizer in a broad stream, six inches wide, across the bottom of furrow.

The drill tube, through which the seed is dropped, about two inches below the fertilizer is immediately followed by a pair of large steel discs, adjustable, and covering the row with a full, free covering.

The seed is not punctured or injured. Neither can any injury result from contact of seed with fertilizer, as the former is deposited below the fertilizer, and the latter is also thoroughly mixed with soil. No waste of fertilizer material, as the flow can be instantly shut off. Plants at distances of $12,15,17,181 / 2$ or 20 inches.

The draft of the machine is light, the wheels being high, with wide concare rims. The draft also depends upon the depth of planting and the angle at which the discs are set. No side draft is possible, as the gearing is driven from both wheels.

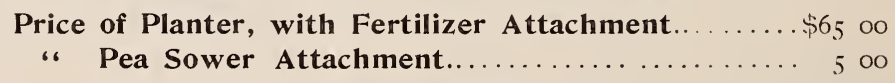

\section{TESTIMONIALS.}

Newport, R. I., Jan. 9, I899. Walter A. Potter \& Co.

Gentlemen: We have used the Robbins Potato Planter two (2) years and have only good words to say about it. Have planted eighteen (IS) acres of potatoes each rear, and the more we use the planter the better zue like it.
Middletown, R. I., Jan. 11, IS99. Walter A. Potter \& Co.

Gentlemen: I have used both the and Robbins Potato Planters; and consider the Robbins Planter far superior to the
I) Avid E. Chase, Albert L. Chase.

\section{Yours truly,}

II. D. DeBlois, Jr. 


\section{The Superior Steel Field Roller.}

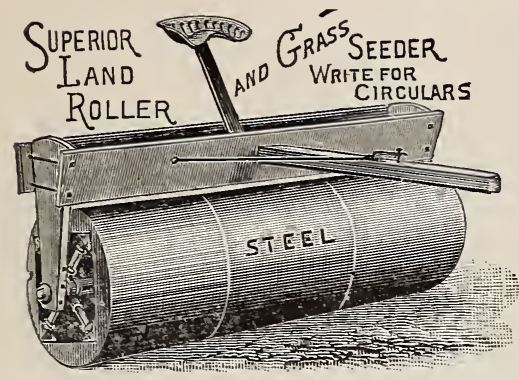

Each section of this roller is made from a single sheet of hardened steel, rolled and riveted at the edge, and supported by oak felloes and wrought iron spokes. The spokes are double nutted and fit into iron corner blocks, which firmly lock together the rims, felloes and boxes.

\section{NET PRICES.}

No. 3, 6 ft. 3 sec............ \$27 oo

No. 7,7 “ 3 “ “

One Horse, 4 ft. $2 \mathrm{sec} \ldots \ldots \ldots \ldots \ldots 24$.

Seeder attachment, complete, for $6 \mathrm{ft}$. roller, $\$ 9.00 ; 7 \mathrm{ft}$. roller, $\$$ ro.oo.

\section{Stevens Fertilizer Sower.}

The success, the past season, of this Fertilizer Sorrer has been beyond the inventor"s most sanguine hopes. It has proved all and even more than was claimed for it, and with the new' and valuable improvements, made for this season, it is far in advance of any other sower on the market. We guarantee perfect satisfaction on every machine.

The machine is furnished with combined pole and shafts. In this combination the crooked shafts are used, orercoming the great objection to the straight shaft combination.

The fertilizer gauge is attached to the top of the box, the adjustment for sowing the fertilizer (from 200 to $4.000 \mathrm{lbs}$. per acre), being made by a lever so simple, a boy can operate it.

Send for full descriptive circular.

Price. $\$+5$ co

\section{"Advance" Fertilizer Drill.}

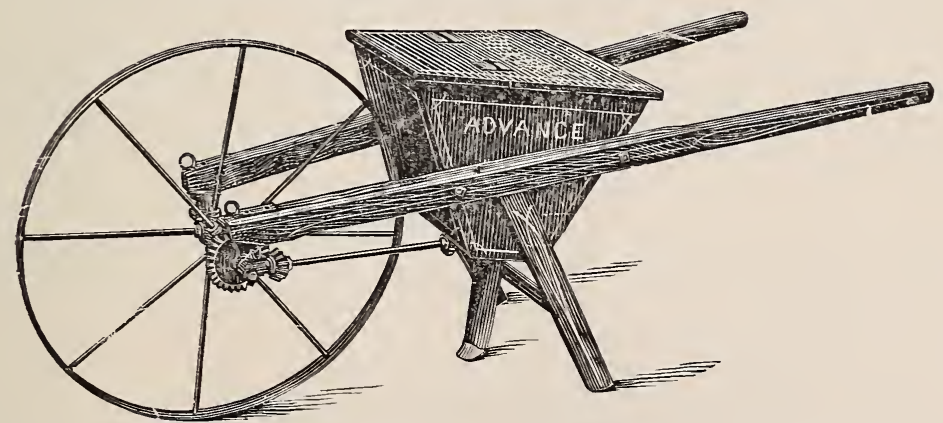

We claim the "Advance" to be the best low priced distlibutor on the market, and would call attention to its distributing disc, of galvanized iron, which can neither break nor rust; also to the wrought iron wheel, light and strong.

A shut-off to prevent the escape of fertilizer when wheeling around the end of row is a late improvement. The "Adrance" is also a first-class tool for the delivery of peas and corn.

Price.............................. $\$_{7}$ co 


\section{THE DEERING IDEAL MOWERS.}

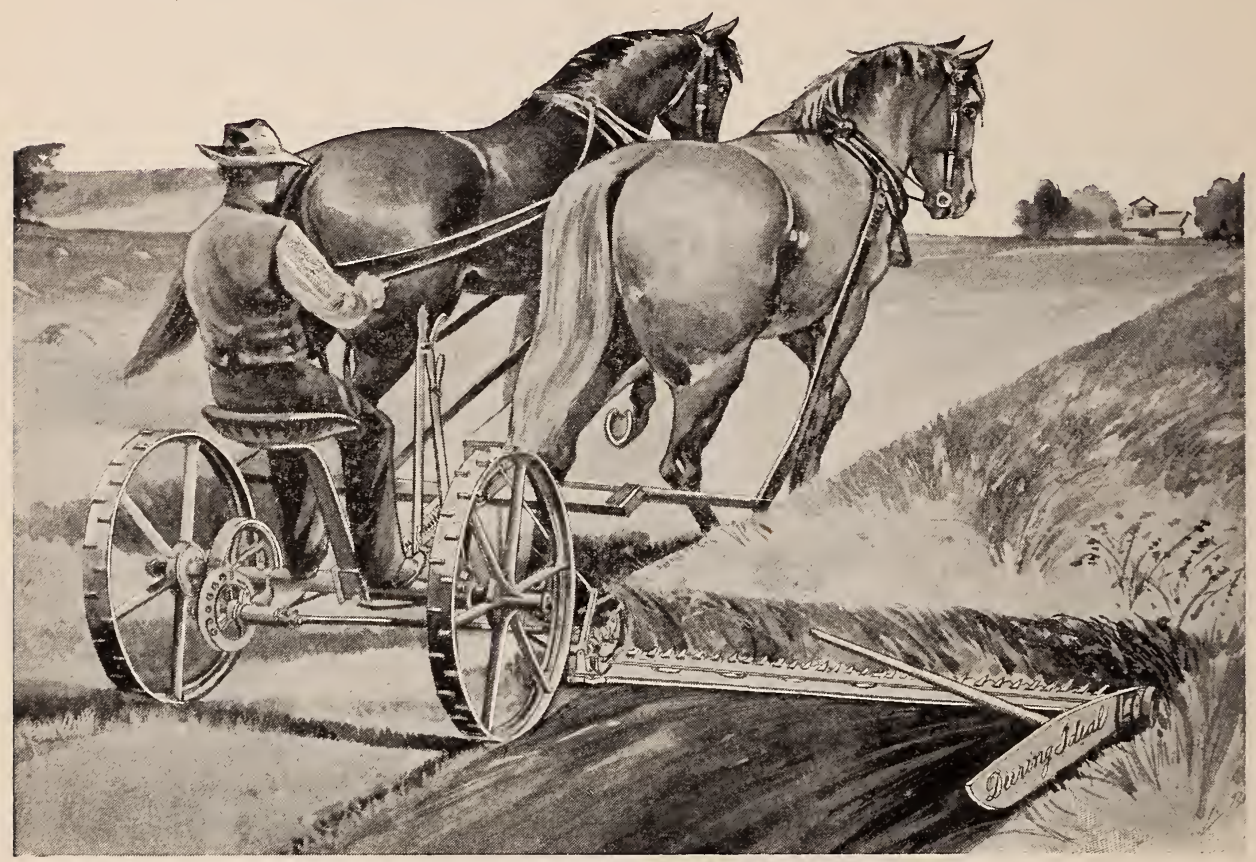

The success of the Deering Ideal Mowers has been largely due to their ease of operation in all conditions of grass, due in part to the roller and ball bearings, as well as to the correct principles upon which the machines are constructed.

So positive is the action of the gearing on the Deering Ideal that the knife starts the instant the wheels move, and the machine can be started without backing the team in the most difficult crops. The horizontal crank shaft allows the pitman to run easy without the jarring and wabbling on most mowers. A few of its many other good points are a floating cutter bar, serrated ledger plates and the adjustable drag bar that keeps the cutter bar in line, the knives in register, and at the same time protects the pitman.

\section{TESTIMONIALS.}

Reновотн, Mass., Jan. ı6, i899. To W. A. Potter \& Co.

Dear Sirs: Having thoroughly tested the Deering Ideal Mower I bought of you in 189.5 , I can truthfully say that in my opinion there is no better mower made. I am well satisfied with it in every respect. The foot lift is the best I have ever seen on any mower. I have sold several since you gave me the agency and they are all giving best of satisfaction. I shall expect to sell more this season than ever.

Yours,

W. B. Munroe.
Cranston, R. I.

Messrs. W. A. Potter \& Co.

Gentlemen: The 5 foot Deering Ideal Nower purchased of you last season, is all you claimed for it. I am fully satisfied with the machine and can honestly recommend it to any one desiring a first class up-to-date mower.

Yours truly,

Cinas. H. Stone. 


\section{DEERING SELF-DUMP RAKE.}

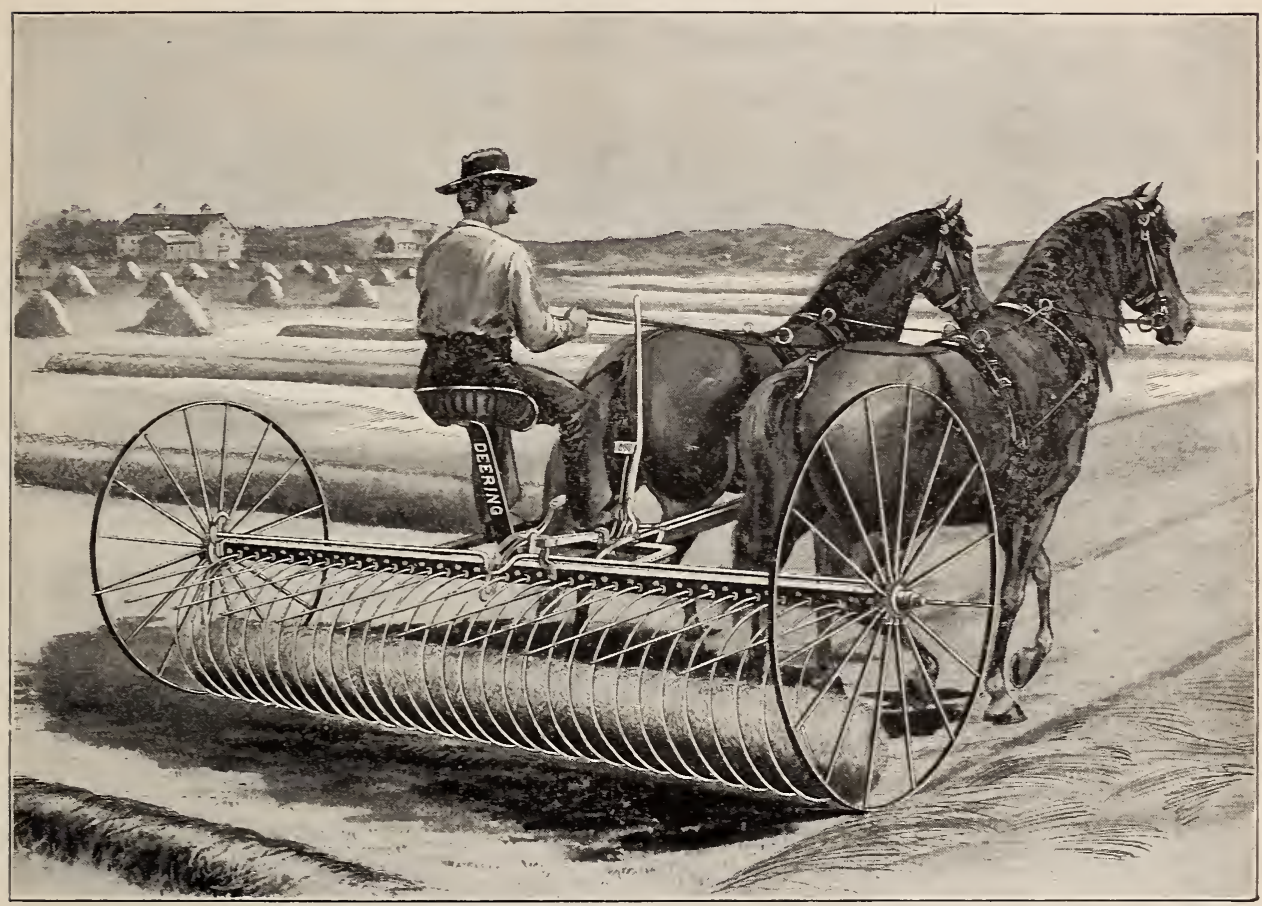

The Deering Hay Rakes are made to give long and satisfactory service under the most difficult conditions.

Though only four years before the public, they have already taken first place among the rakes.

Their popularity is due to three things: Their durability, their economy, their ease of operation. Their durability is due to the fact that they are well made from sensible designs out of good steel. Their economy is due to the shape of the teeth. which enables the machine to clean the ground perfectly without scratching it, and to the freedom from breakage throughout the whole mechanism. Their ease of operation is due to the fact that like the Deering mower they are built on right principles.

The teeth are secured to the angle steel head independently of each other.

To replace a tooth, it is only necessary to remove one bolt.

\section{RELIABLE SELF-DUMP RAKE.}

This rake has the loose coil flat point tooth, a continuous steel axle, with a truss rod supporting the head preventing all danger of sagging. There is no slot board, but a slot in the back of the head itself, making the teeth perfectly loose and independent, allowing them to adapt themselves to uneven, rough and rocky ground. The dumping cog wheel is in the centre of the axle and entirely enclosed. The castings are largely malleable, and the rake is furnished with combined pole and shafts. In all respects it is a Reliable Rake. 


\title{
THE THOMAS HAY TEDDER.
}

\author{
The only Successful Tedder in Heavy Hay.
}

For One or Two Horses, as Desired.

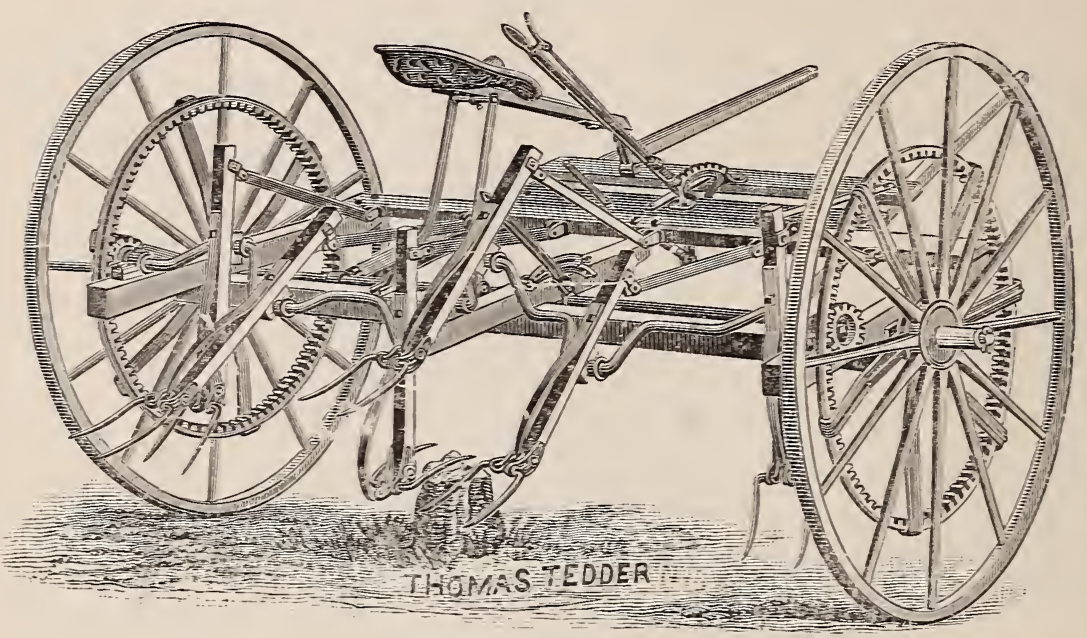

The "Thomas" Tedder is so far ahead of all other tedders on the market that it must be seen and examined to realize its great superiority. A tedder gets so much jarring and racket in the field that it must be very strong throughout, and right there most tedders fail. A continuous steel axle is used to prevent the rish of bending or breaking.

A spring is placed on front of the frame. which has a scope of six inches. By this method, when the fork strikes a stone. the frame is reliered and prevents breakage. Steel crank shafts are also used perfectly fitted. the journal and bearings reducing wear and friction. The steel fork is separate from the spring. and the greatest tension of the spring is when the fork is in position to use. As the fork is bent back by an obstruction the tension of the spring becomes weaker, allowing the fork to pass orer a larger obstruction than any other tedder.

This tedder throughout is built in a most substantial manner, and of the rerr finest and strongest material, and though costing at first a little more than some others. will outlast two of any other make on the market.

\section{THE STEEL ROYAL TEDDER.}

To meet the demand for an all-steel outside-fork Tedder we offer the Roval. It is the strongest steel tedder with outside forks. The frame is made of steel angle bars and the wheels are steel with channel tires to prerent slipping. This Tedder is compact, solid and substantial, and attractive in appearance. It is furnished with combined pole and shafts. 


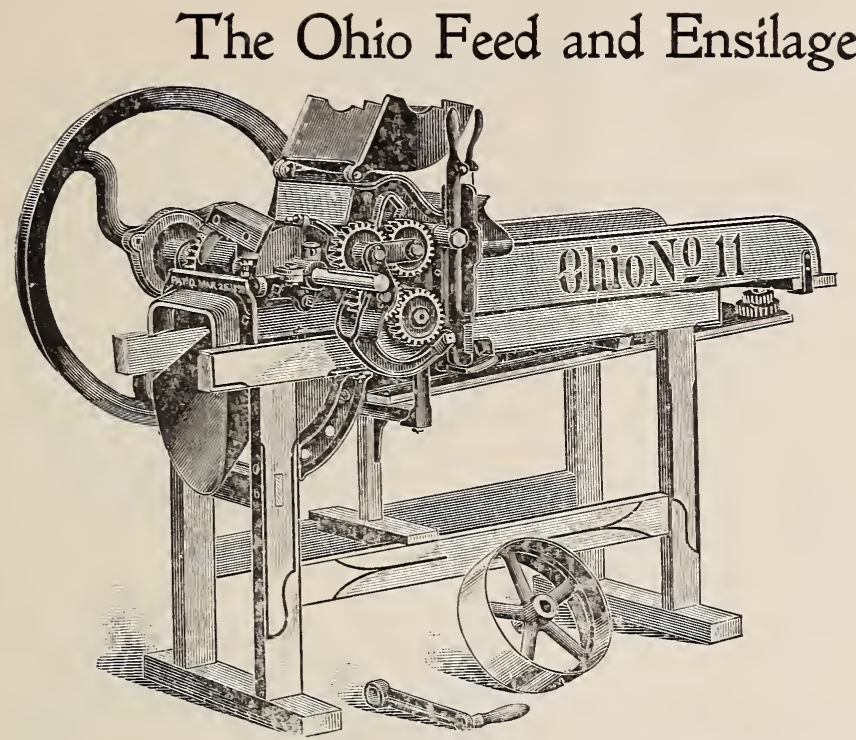

\section{Cutter.}

These cutters by reason of the wide open throat and improved feeding derice have a larger capacity than others. The knife shafts are steel. The bearings are wide and heary and babbitted with high grade metal. The knives are secured to the solid knife head by lock nuts to prevent working loose and are backed up by set screws to hold them in place.

Sizes and Prices of Cutters Carried in Stock.

No. 9, Hand Power, 4 knives....... List price......\$40 oo

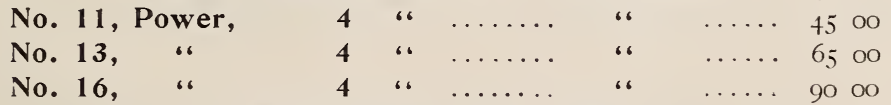

WRITE FOR DISCOUNT.

\section{CARRIERS OR ELEVATORS.}

When ordered, we furnish Carriers for Nos. II, I3, I6 and is "Ohio" Standard Cutters. which adapts them for elevating the material after it is cut.

The use of the Carrier in connection with Feed Cutters to elevate dry fodder into bins, lofts, etc., as well as green fodder into the silo, is daily increasing. It serves to keep the fodder away from the front of the machine, and by delivering it directly in to the store-house, dispen-es with one or two hands, which is a great saving to the operator. We consider the Carrier indispensable where large quantities of fodder are to be cut. Our Carriers are made of the best materials, and give perfect satisfaction.

\section{SHREDDER CYLINDERS.}

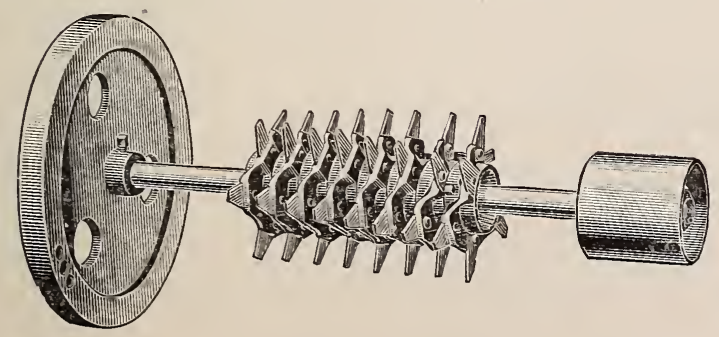

We can furnish for the Ohio cutter shredder cylinders for dry fodder which are interchangeable with the knife cylinder for the No. $1 \mathrm{I}$ and up. The shredder head is made up of a number of parts so that in case of breakage the cylinder is not entirely destroyed as is the case with most makes.

Send for full descriptive circular of these cutters. 


\section{POULTRY SUPPLIES.}

Bowker's Animal Meal. It is not a stimulant, but a true animal food and is not intended to take the place of grain, grit or vegetables; but is a splendid substitute for meat, bones and shells. It is prepared from fresh beef and bones which are dried and cooked by steam, and then ground to an easily digested meal that is sweet, palatable and nutritious. Per 10o lb. bag, \$2.00.

Bone Meal. For mixing with soft feed, this is unsurpassed. Laying hens and young chicks are much benefited by this, especially during the winter months. Put up in $25 \mathrm{lb}$., $50 \mathrm{lb}$. and Ioo lb. bags. Price per pound, $21 / 2$ cents.

Cut Clover. Prepared to meet the demand for a natural vegetable food. Price per $50 \mathrm{lb}$. bag, \$r.oo; per roo lb. bag, $\$ 2.00$.

Clover Meal. This is a clover hay ground to a fine meal, similar to middlings, and can be fed as easily. It promotes the health by enriching the blood and toning up the system. Price per $50 \mathrm{lb}$. bag, $\$$ r.oo.

Sheridan's Condition Powders. It is a powerful food digestive; therefore it assures perfect assimilation of the food elements. Strictly a medicine, not a food. Price, $2 \mathrm{lb}$. can, So cents; 4 oz. package, 20 cents

Darling's Ground Beef Scraps. These are strictly first quality, being ground from perfectly fresh meat. Price per Ioo $1 \mathrm{~b}$. bag, $\$ 1.85$ and $\$ 2.00$.

Ground Oyster Shells. These are thoroughly washed, dried and made sweet, then reduced to a size that easily passes through a screen of one-half inch mesh. Price per Ioo $\mathrm{lb}$. bag, 60 cents.

Mica Crystal Grit. This grit is prepared to meet the demand for a sharp, clean grit of a regular size, and has been thoroughly tested. Price per Ioo lb. bag, 75 cents.

Pratt's Poultry Food. The guaranteed egg producer. Makes larger fowls and quickens the growth of young chickens. Prevents and cures all poultry diseases. Price, 26 oz. pkg., 25 cents; 5 lb. pkg., 60 cents; 12 lb. bag, \$1.25; 25 lb. bag, \$2.50.

Cracked Poultry Bone. Put up in $25 \mathrm{lb}$., $50 \mathrm{lb}$. and $100 \mathrm{lb}$. bags. Price per $\mathrm{lb} ., 2 \mathrm{l} / 2 \mathrm{c}$.

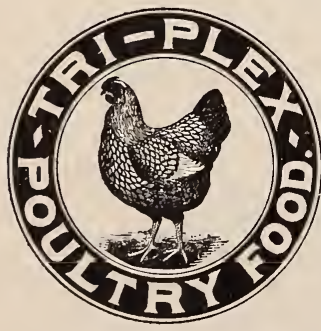

Vegetable Cutter, Banner. Will cut all roots and vegetables into fine chicken feed, leaving the cut feed in shape resembling little angle worms. They solve the problem of green food in winter. Price, $\$ 5.00$.
Tri=Plex Poultry Food. As Tri-Plex Poultry Food is not weighted with ground shell, or made bulky with inert material, it is, beyond question, the best poultry food in the market, and the cheapest to use. Price, 26 oz. pkg., 25 cents; 5 lb. pkg., 60 cents.

Tri=Plex Stock Food. It is so named because of its triple power of regulating the stomach, liver, and kidneys of animals. It keeps these important organs in order, so that diseases are prevented and cured, and robust health assured. Price per $7 \mathrm{lb}$. bag, 50 cents. 


\section{DRINKING FOUNTAINS.}

Hub (Galvanized Iron) I gallon each.......\$ 75

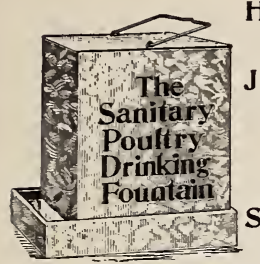

" " 6 6 " 6 "

Jug Shape (Earthen) I quart each....... 20

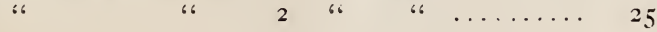

$\begin{array}{llllllll}6 & 6 & 3 & 6 & 6 & \ldots \ldots \ldots & & 6\end{array}$

$\stackrel{4}{4} \quad \ldots \ldots \ldots . . .64$

Sanitary (Galvanized Iron) I gallon each..... 50

Pumps, Tin Force. Useful for applying whitewash, each, $\$$ I.oo.

Thermometers. Standard incubator. Each, 50 cents.

Brass Leg Bands. Per doz., 20c.; \$1.00 per 100.

Brushes, Whitewash. For use in henhouse. Each, 50c., 75c.,

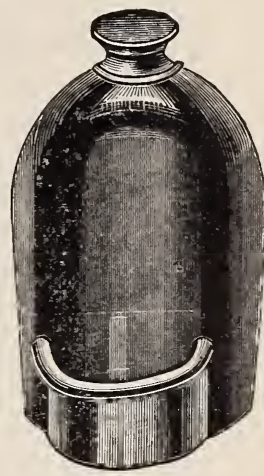
$95 \mathrm{c} ., \$ 1.10$

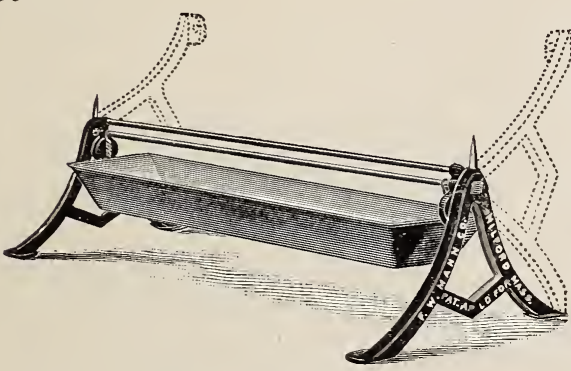

Mann's Swinging Feeding Tray. Hens cannot scratch the food out or the dirt in. The weight of the hen tips the tray and throws her off. Upper rod tips also if the hen tries to roost over the pan. Price, IS in., \$I.OO; 27 in., \$1.25; 36 in., \$1.50.

French Poultry Killing Knife. Made of finely tempered tool steel with nickel handle. Price each, $50 c$.

Poultry Netting. Clinton, Gilbert \& BenIOO sq. feet, $42 \mathrm{c}$. net best make. All widths from I to $6 \mathrm{ft}$, per

Chicken Netting. Closer mesh than the poultry. All widths. Per Ioo sq. ft., \$I.Io. Nest Eggs, China. The best and cleanest nest egg. Per dozen, $25 \mathrm{c}$.

Caponizing Sets. Price complete with instructions, per set, $\$ 2.50$. Complete in velvet lined case, $\$ 2.75$.

Marking Punches. Nickel-plated with steel cutter and spring. Price, $25 \mathrm{c}$. each.

Lambert's Death to Lice. A cheap and effective remedy for all poultry vermin. Price, 5 oz. pkg., IOc. : I5 oz. pkg., 25c.; 48 oz. pkg., 5 Oc.; 100 oz. pkg., \$1.oO.

German Roup Pills. These pills act directly on the glands and mucous membrane allaying all tendencies to fever. Price, per box. $25 \mathrm{c}$.

\section{MANN'S GREEN BONE CUTTERS.}

No. 1, With Crank.............................. $\$ 5$ oo

No. 1B, " Balance Wheel...................... 7 oo

No. 3, " " " $" \ldots \ldots \ldots \ldots \ldots, \ldots \ldots \ldots \ldots \ldots$ I2 00

No. 3, Mounted, with Balance Wheel ................. I5 oo

No. 2, " $\quad$ " $\quad$ " $\quad$ "

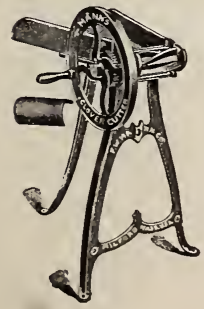

\section{MANN'S CLOVER CUT'TER.}

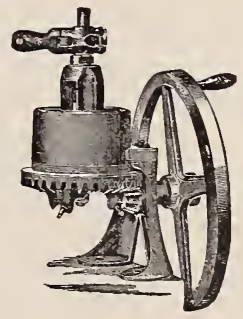

Cuts any kind of hay or clover, either dry or green, and more rapidly than any other. Every revolution of the balance wheel produces twelve cuts. All dangerous parts are enclosed.

Price, with legs $\ldots \ldots \ldots \ldots \ldots \ldots \ldots \ldots \ldots$. $\ldots \ldots \ldots$

" without legs $\ldots \ldots \ldots \ldots \ldots \ldots \ldots \ldots$ \& oo 


\section{Water Barrel Truck, Hand Cart, Leaf Rack, Etc.}

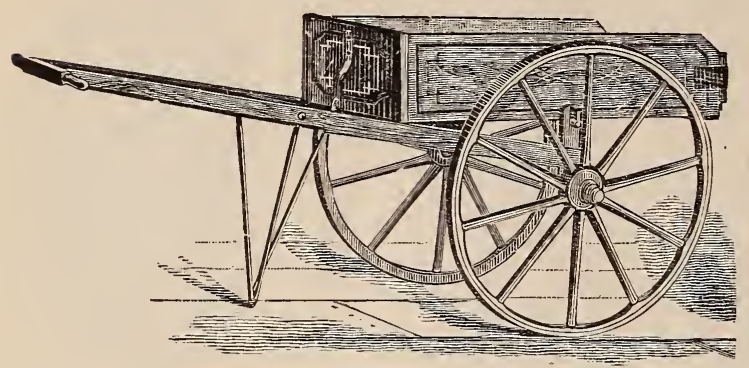

The Barrel is raised from the ground, carried to the place desired and can be readily detaclied fron 1 the truck while barrel is either full or empty. The body witl trunions and spring catch make a very superior dumping liand cart. The Leaf Rack will be found extremely convenient for removing leaves, cut grass from the law11, etc. Knocks down flat, taking very little room for storage. We have steel wheels $1 \frac{1}{2}, 21 / 2$ and $31 / 2$ incli tire, but always send truck with wheels $\mathrm{I} 1 / 2$ inch tire 111 less otherwise specified. A Force Pump can be attached to the barrel and used for spraying trees and shrubbery with insecticides, watering plants and lot beds, etc.

Truck $\mathrm{x} 1 / 2$ incli tire, $\ldots \ldots \ldots \ldots \ldots \ldots \ldots \ldots 7$ oo

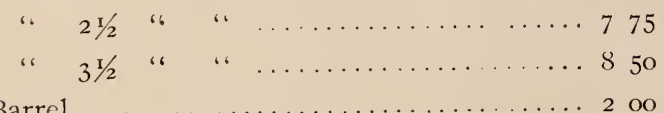

Barrel ...... ...................................... 75

Hand Cart Box................... 275

Leaf Rack...................... 4 oo

Force Pump.................... 5 oo

Extra Trunions, pair........... 50

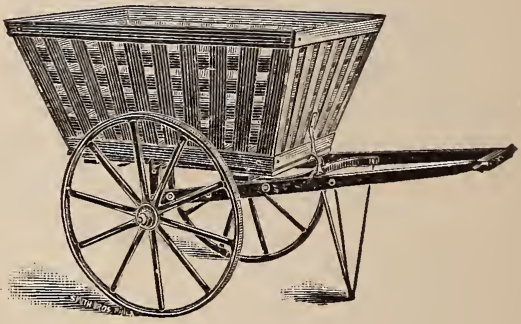

\section{COLDWELL'S IMPROVED HORSE LAWN MOWER.}

We guarantee this to be the best made. It has sidedraft attachment to enable the horse to walk on the cut grass only, and caster rollers wlich will not mark the lawn. The evenness of cut is secured by an adjustment which raises and lowers the two sides at the same time by means of a simple lever movement; the same lever raises the knives from the ground when driving over gravel walks or roads. The nowers are fitterl with steel shafting and contposition split bushings. The utmost care is taken to have the work manship perfect.

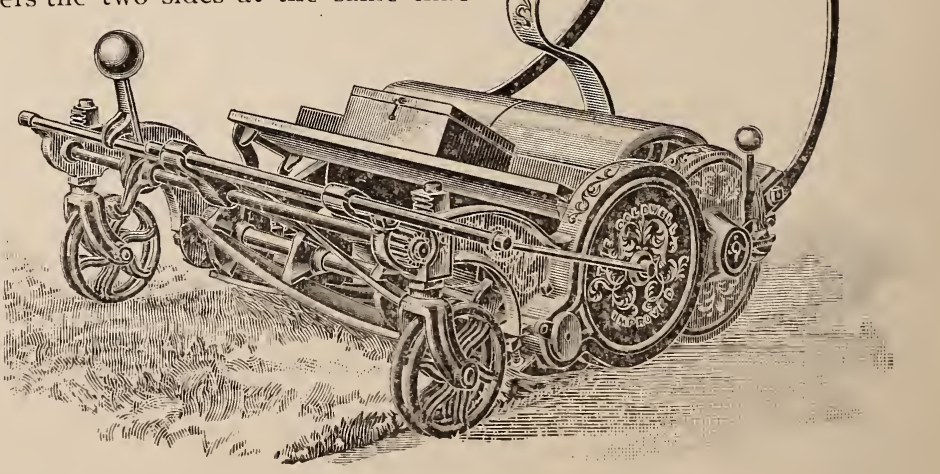

Price, 35 inch cut, $\$ 75.00 ; 30$ inch cut, $\$ 65.00$. 


\section{LAWN VASES.}

FINISHED IN TERRA COTTA.

These Vases are made of the same material as the ordinary Hower pot, attractive in appearance and superior to those of cast iron.

No. 373 (see cut) 26 inches diameter, I9 inches high; Capacity 2 bushels. Pedestal 23 inches high. Price complete, $\$ 18.00$.

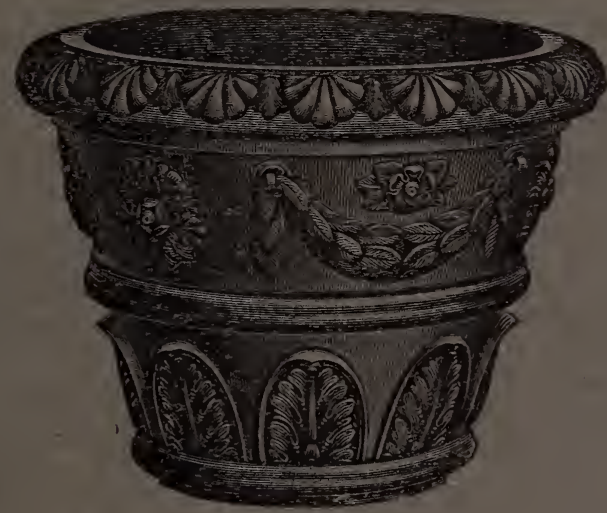

No. 370,28 inches diameter, 20 inches high; Capacity $3 \frac{1}{2}$ bushels. Pedestal 24 inches high. Price complete, $\$ 26.00$.

No. 374,25 inches diameter, $19 \frac{1}{2}$ inches high; Capacity 3 bushels. Pedestal 20 inches high. Price complete, $\$ 16.00$.

No. 389, I9 inches diameter, ${ }_{5} 5$ inches high; Capacity I bushel, with saucer. Price $\$ 4.50$. 


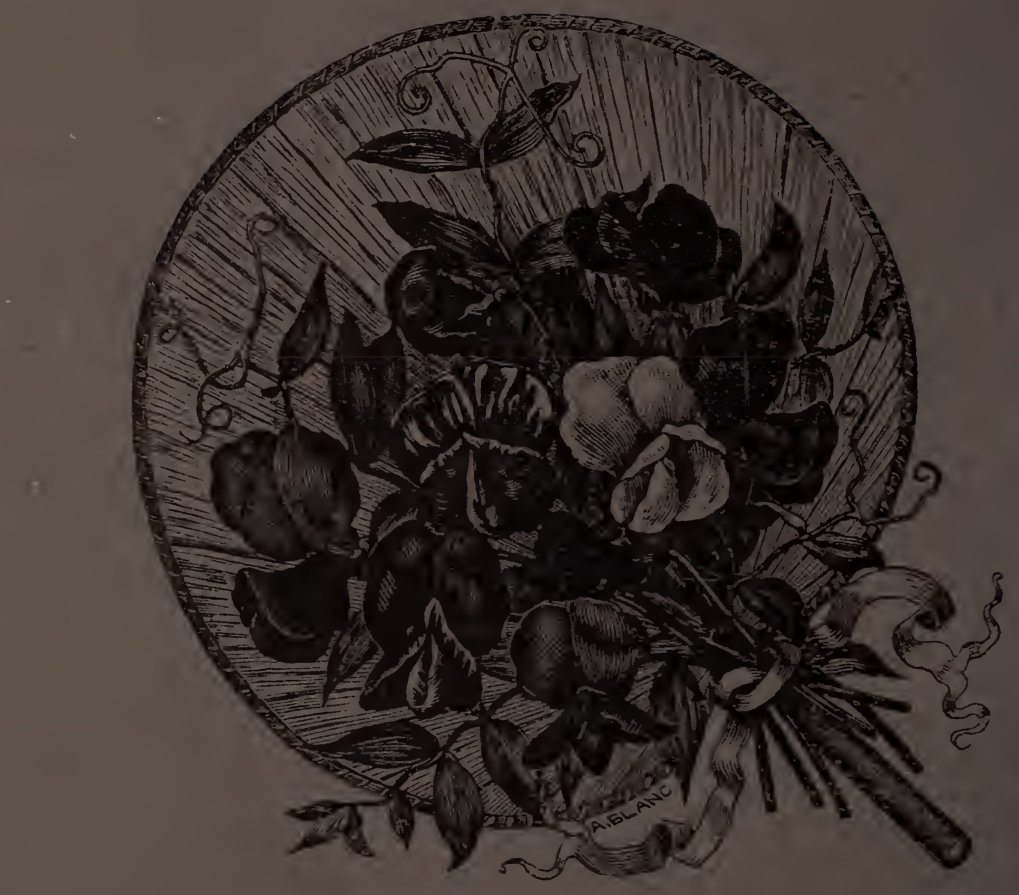

